
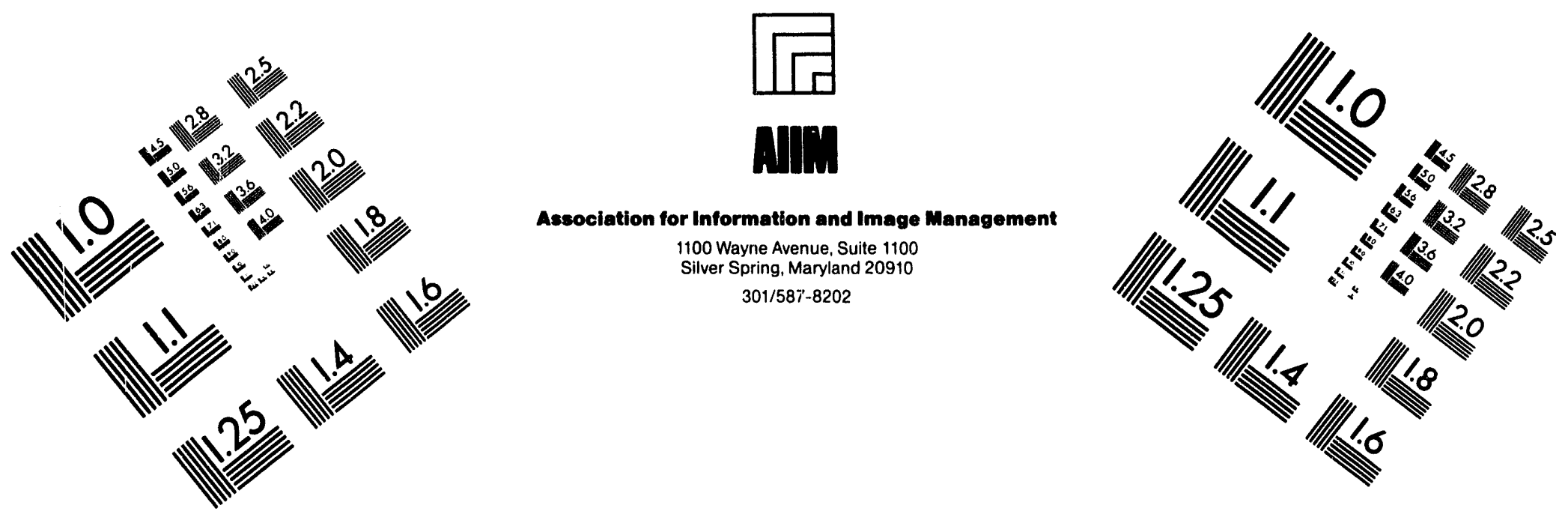

\title{
Centimeter
}

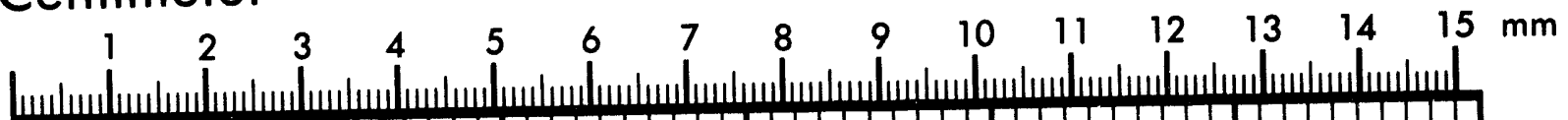

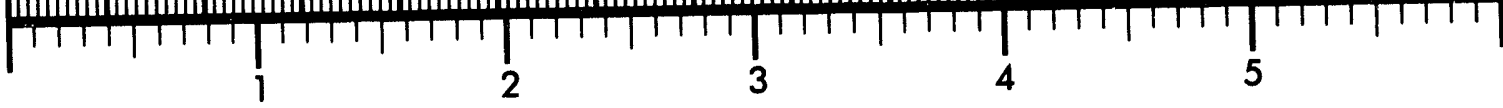
Inches
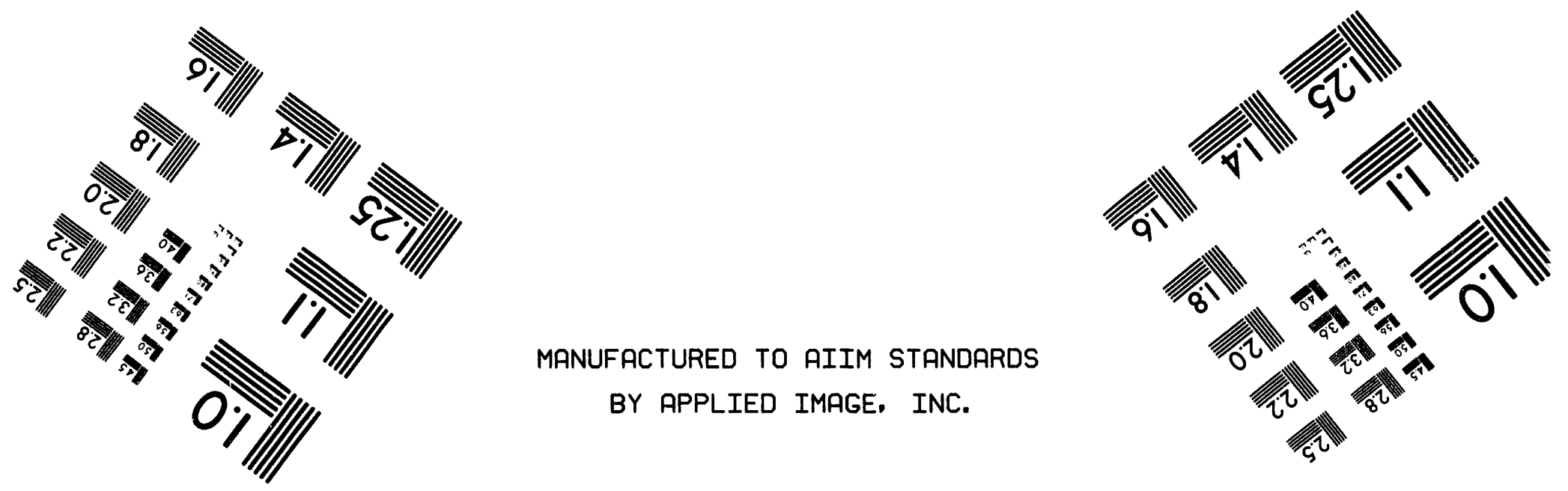

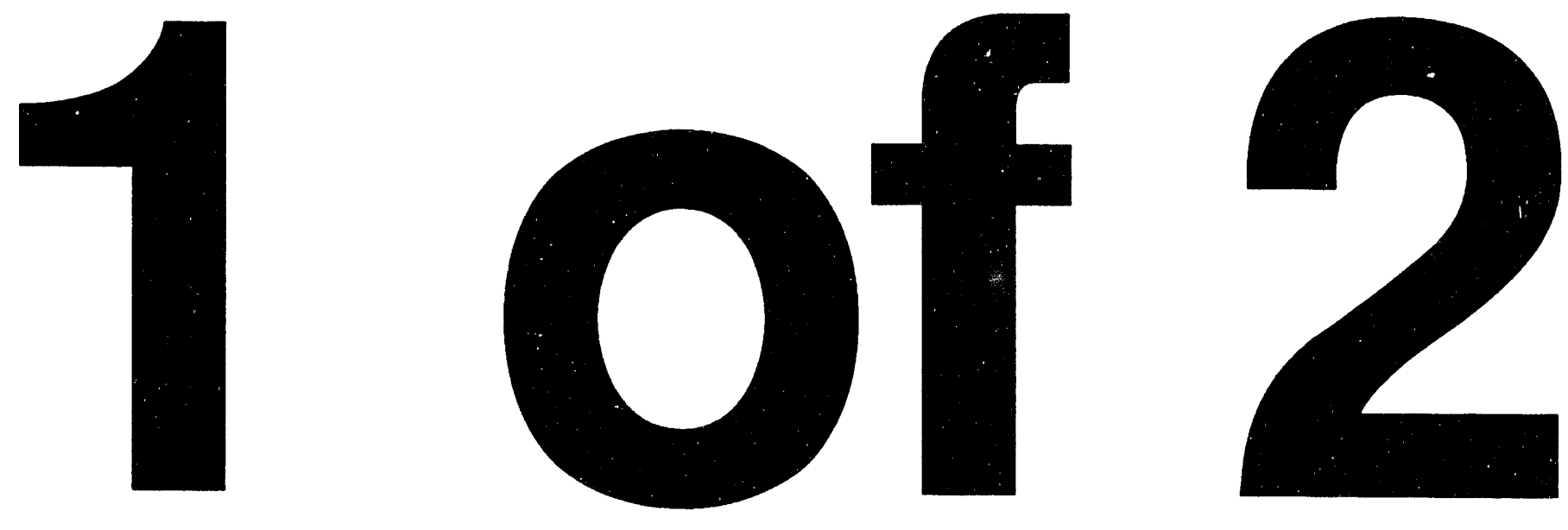
NUREG/CR-5850

BNL-NUREG-52319

\section{Analysis of Long-Term Station Blackout Without Automatic Depressurization at Peach Bottom Using MELCOR (Version 1.8)}

Manuscript Completed: April 1994

Date Published: May 1994

Prepared by

I. K. Madni

Brookhaven National Laboratory

Upton, NY 11973

Prepared for Division of Systems Research Office of Nuclear Regulatory Research U.S. Nuclear Regulatory Commission

Washington, DC 20555-0001

NRC FIN A3281 


\begin{abstract}
This report documents the results from MELCOR calculations of the Long-Term Station Blackout Accident Sequence, with failure to depressurize the reactor vessel, at the Peach Bottom (BWR Mark I) plant, and presents comparisons with Source Term Code Package calculations of the same sequence. STCP has calculated the transient out to $\mathbf{1 3 . 5}$ hours after core uncovery. Most of the MELCOR calculations presented have been carried out to between 15 and 16.7 hours after core uncovery. The results include the release of source terms to the environment.

The results of several sensitivity calculations with MELCOR are also presented. These explore the impact of varying user-input modeling and timestep control parameters on the accident progression and release of source terms to the environment.
\end{abstract}




\section{Table of Contents}

Page No.

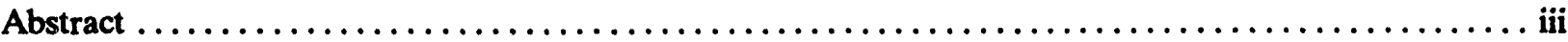

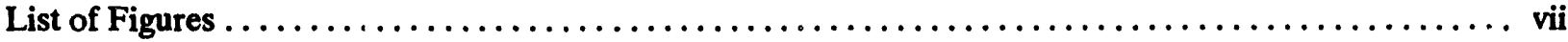

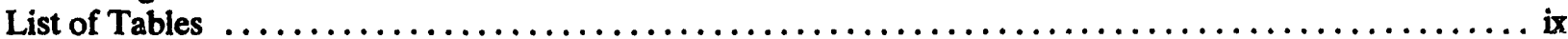

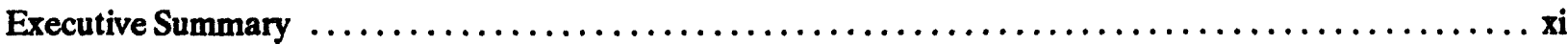

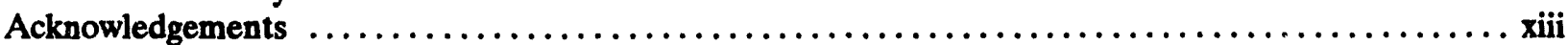

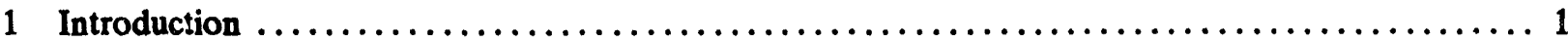

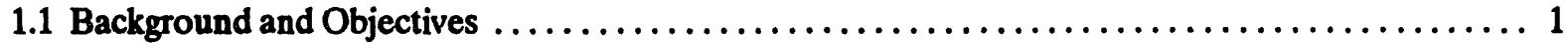

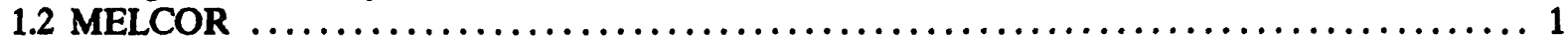

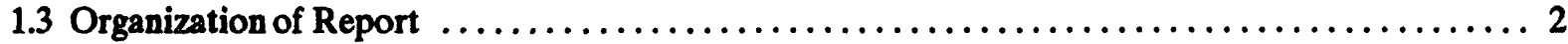

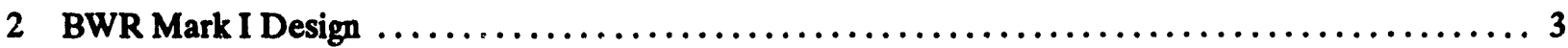

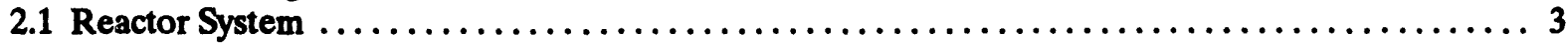

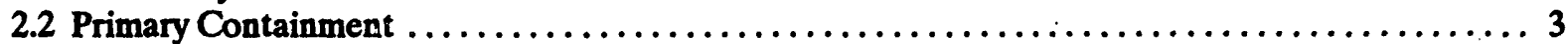

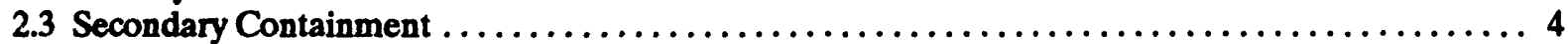

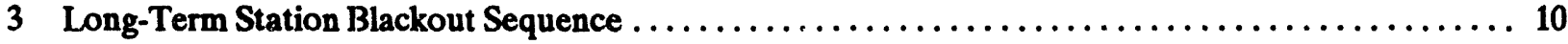

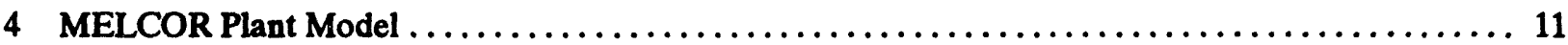

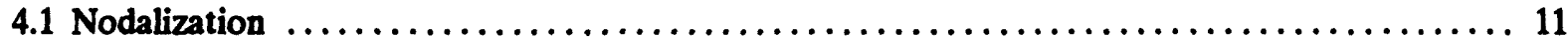

4.2 Some Features of Simulation $\ldots \ldots \ldots \ldots \ldots \ldots \ldots \ldots \ldots \ldots \ldots \ldots \ldots \ldots \ldots \ldots \ldots \ldots \ldots$

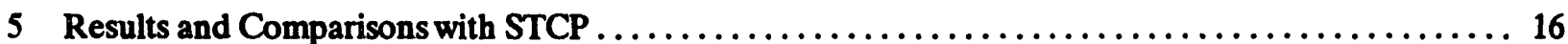

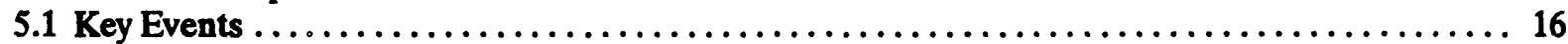

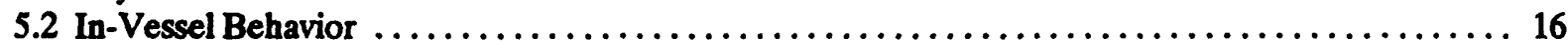

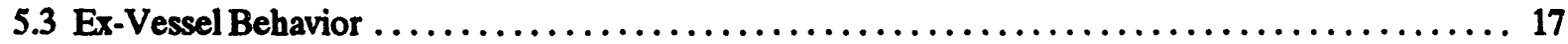

5.4 Fission Product Transport and Release to Environment $\ldots \ldots \ldots \ldots \ldots \ldots \ldots \ldots \ldots \ldots \ldots$

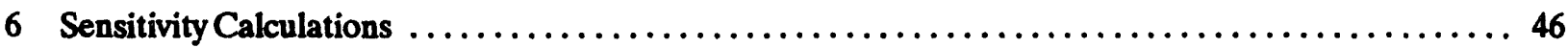

6.1 Fuel Release Models .............................................. 46

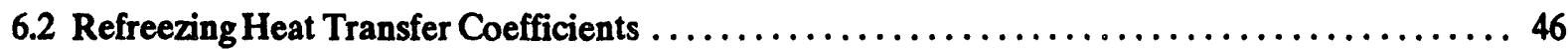

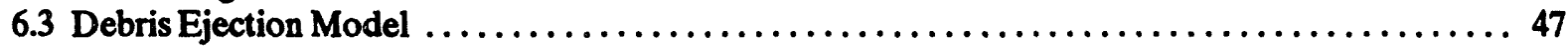

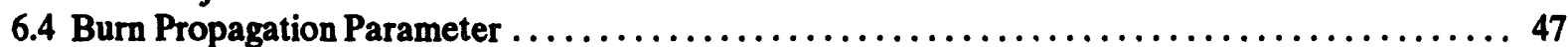

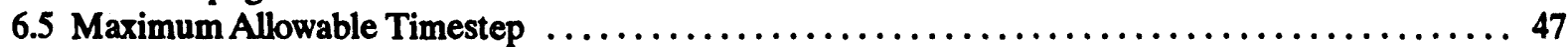

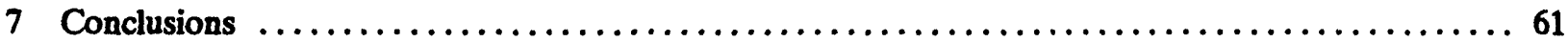

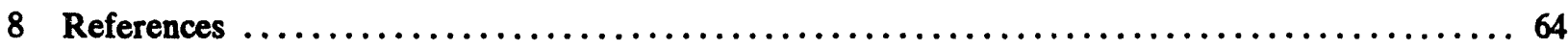

Appendix A Comparison of Results with MELCOR 1.8BC and MELCOR 1.8CZ ......... A-1

Appendix B Additional Calculations and Findings from MELCOR 1.8DNX $\ldots \ldots \ldots \ldots \ldots \ldots$ B-1

B.1 Impact of Maximum Allowable Timestep $\left(\Delta \mathrm{t}_{\max }\right)$ on Peach Bottom Station Blackout Calculations Using MELCOR 1.8DNX ................ B-1

B.2 Examination of Lower Plenum Dryout Times as Calculated by MELCOR, Version 1.8DNX ................................... B-7

B.3 Effect of Operating System Math Run Time Library Routines on MELCOR Calculations ....................................... B-11 


\section{Table of Contents (Cont'd)}

Page No.

Appendix C Additional Calculations and Findings from MELCOR $1.8 .2 \ldots \ldots \ldots \ldots \ldots \ldots \ldots \ldots$-1

C.1 Impact of Maximum Allowable Timestep on Peach Bottom Station Blackout C.1

C.2 Impact of Debris Fall Velocity in the New Debris Quench Model on Peach Bottom

Station Blackout Calculations Using MELCOR 1.8.2 .............. C-22

C.3 Implementation of ORNL's Lower Plenum Debris Bed (BH) Model ........ C-25 


\section{List of Figures}

Figure No.

Page No.

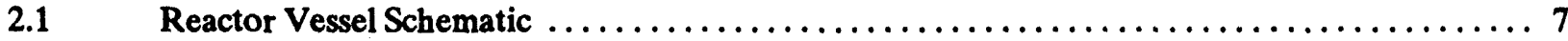

2.2

2.3

4.1

4.2

5.1

5.2

5.3

5.4

5.5

5.6

5.7

5.8

5.9

5.10

5.11

5.12

5.13

5.14

5.15

5.16

5.17

5.18

5.19

5.20

5.21

5.22

5.23

5.24

5.25

B.1

B. 2

B. 3

B. 4

B.5

B. 6

B. 7

B. 8

B.9

C. 1

C. 2

C. 3

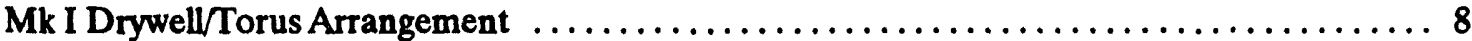

Schematic of the Containment Design for the Peach Bottom Plant $\ldots \ldots \ldots \ldots \ldots \ldots \ldots \ldots 9$

Peach Bottom Plant Nodalization for MELCOR $\ldots \ldots \ldots \ldots \ldots \ldots \ldots \ldots \ldots \ldots \ldots \ldots \ldots$

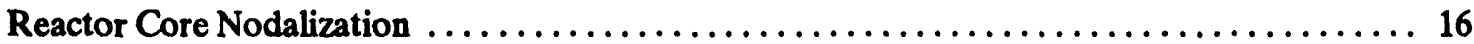

Total and Steam Partial Pressures in the RPV Separator and Dryer Regions Calculated by

MELCOR ................................................. 21

Vessel Water Level Calculated by MELCOR $\ldots \ldots \ldots \ldots \ldots \ldots \ldots \ldots \ldots \ldots \ldots \ldots \ldots, 22$

MELCOR-Calculated Cumulative Steam Flow Through the SRV Line $\ldots \ldots \ldots \ldots \ldots \ldots \ldots 23$

MELCOR-Calculated Cumulative Hydrogen Flow Through the SRV Line $\ldots \ldots \ldots \ldots \ldots \ldots 24$

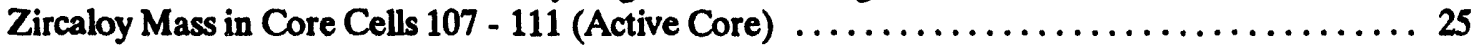

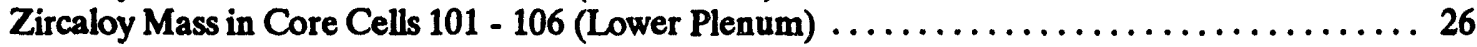

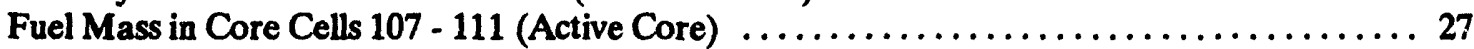

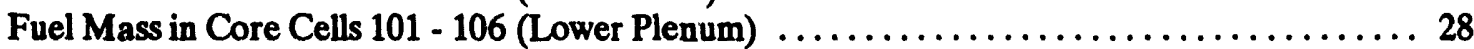

Cumulative Hydrogen Production Calculated by MELCOR $\ldots \ldots \ldots \ldots \ldots \ldots \ldots \ldots \ldots . \ldots \ldots$

Total and Steam Partial Pressure History in the Drywell $\ldots \ldots \ldots \ldots \ldots \ldots \ldots \ldots \ldots \ldots \ldots$

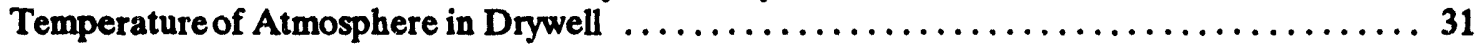

Temperature Response of the Upper and Lower Reactor Pedestal $\ldots \ldots \ldots \ldots \ldots \ldots \ldots \ldots, \ldots \ldots \ldots$

Temperature Response of the Drywell Line and Floor $\ldots \ldots \ldots \ldots \ldots \ldots \ldots \ldots \ldots \ldots, \ldots \ldots$

Total and Steam Partial Pressure History in the Wetwell $\ldots \ldots \ldots \ldots \ldots \ldots \ldots \ldots \ldots \ldots, \ldots \ldots$

Temperature Response of the Wetwell Pool and Liner $\ldots \ldots \ldots \ldots \ldots \ldots \ldots \ldots \ldots \ldots \ldots$

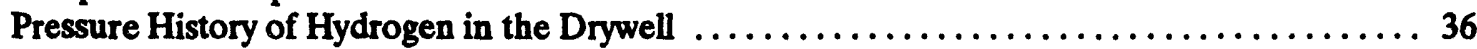

Pressure Response of the Torus Room and Refueling Bay $\ldots \ldots \ldots \ldots \ldots \ldots \ldots \ldots \ldots \ldots \ldots$

Temperature Response of the Torus Room and Refueling Bay $\ldots \ldots \ldots \ldots \ldots \ldots \ldots \ldots . \ldots \ldots$

Accumulated Masses of Metallic, Heavy, and Light Oxidic Debris in the Cavity .......... 39

Temperature History of Debris and Water Layers in the Cavity $\ldots \ldots \ldots \ldots \ldots \ldots \ldots \ldots \ldots$

Cumulative Mass of Non-Condensible Gases Released from Core-Concrete Interaction ..... 41

Cumulative In-Vessel Released and Deposited Mass of Radioactive Fission Products ...... 42

Cumulative In-Vessel Released Mass of CsOH, Te, and CsI . . . . . . . . . . . . . . . . 43

Cumulative Ex-Vessel Released Mass of $\mathrm{CsOH}$, Te, and CsI $\ldots \ldots \ldots \ldots \ldots \ldots \ldots \ldots \ldots 44$

Location History of Decay Heat In-Vessel and Ex-Vessel $\ldots \ldots \ldots \ldots \ldots \ldots \ldots \ldots \ldots \ldots$

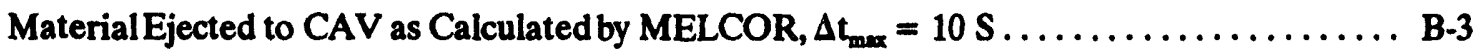

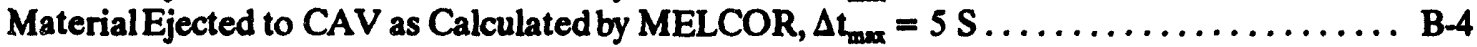

Material Ejected to CAV as Calculated by MELCOR, $\Delta \mathrm{t}_{\max }=3 \mathrm{~S} \ldots \ldots \ldots \ldots \ldots \ldots \ldots$.

Lower Plenum Water Mass Vs. Time ................................. B-9

Lower Plenum Water Mass Vs. Time; Magnifying the Debris Quench Time Scale . . . . . . . B B-10

Pressure History of Hydrogen in the Drywell, VAX/VMS V5.4-1A $\ldots \ldots \ldots \ldots \ldots \ldots \ldots$ B-13

Pressure History of Hydrogen in the Drywell, VAXVMS V5.3-1 ............... B-14

Total and Steam Partial Pressure History in the Drywell, VAX/VMS V5.4-1A $\ldots \ldots \ldots \ldots$ B-15

Total and Steam Partial History in the Drywell, VAX/MMS V5.3-1 ............. B-16

Pressure in the Reactor Pressure Vessel (RPV) $\ldots \ldots \ldots \ldots \ldots \ldots \ldots \ldots \ldots \ldots \ldots \ldots$

Hydrogen Pressure in the Reactor Pressure Vessel (RPV) $\ldots \ldots \ldots \ldots \ldots \ldots \ldots \ldots \ldots$ C-6

Downcomer Level in the Reactor Pressure Vessel (RPV) $\ldots \ldots \ldots \ldots \ldots \ldots \ldots \ldots \ldots$. 


\section{List of Figures (Cont'd)}

Figure No.

Page No.

C.4 Temperature of Atmosphere in the Reactor Pressure Vessel (RPV) $\ldots \ldots \ldots \ldots \ldots \ldots \ldots$ C-8

C.5 Temperature of Atmosphere in RPV Upper Plenum $\ldots \ldots \ldots \ldots \ldots \ldots \ldots \ldots \ldots \ldots \ldots \ldots$ C-9

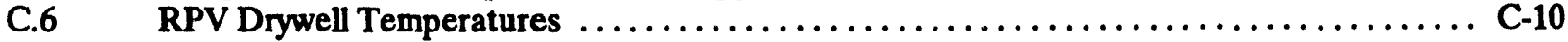

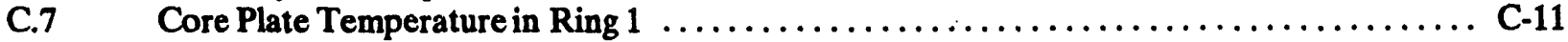

C.8 Total Hydrogen Production in Core $\ldots \ldots \ldots \ldots \ldots \ldots \ldots \ldots \ldots \ldots \ldots \ldots \ldots \ldots \ldots \ldots \ldots \ldots, 12$

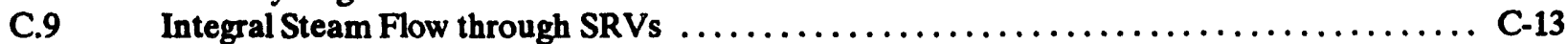

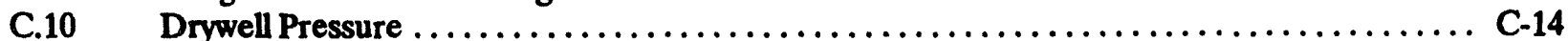

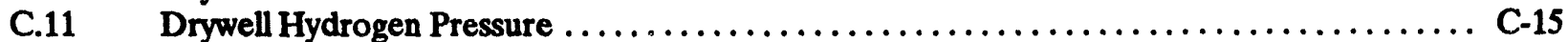

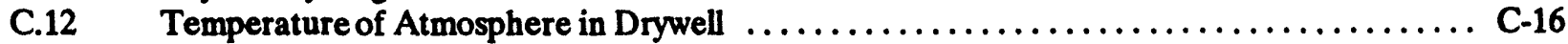

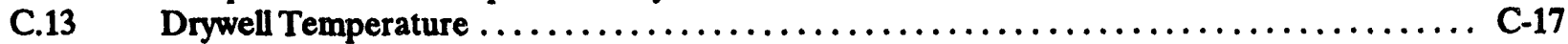

C.14 Wetwell Temperature..............................................

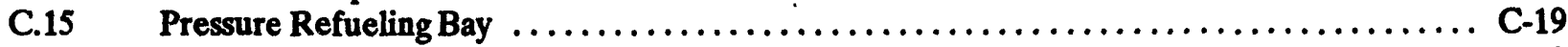

C.16 Temperature of Atmosphere in Refueling Bay $\ldots \ldots \ldots \ldots \ldots \ldots \ldots \ldots \ldots \ldots \ldots \ldots \ldots$ C-20

C.17 Radioactive Mass Deposited on RPV Separators $\ldots \ldots \ldots \ldots \ldots \ldots \ldots \ldots \ldots \ldots \ldots \ldots$ C-21 


\section{List of Tables}

Table No.

Page No.

$2.1 \quad$ Domestic BWR Mark I Design Parameters $\ldots \ldots \ldots \ldots \ldots \ldots \ldots \ldots \ldots \ldots \ldots \ldots$

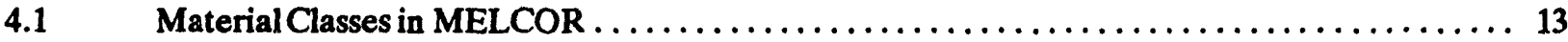

5.1 MELCOR and STCP-Predicted Timing of Key Events $\ldots \ldots \ldots \ldots \ldots \ldots \ldots \ldots \ldots$

5.2 Fractional Distribution of Fission Products by Group in Plant and Environment . . . . . . . . 20

6.1 Impact of Fuel Release Model on Predicted Timing of Key Events ................49

6.2 Impact of Fuel Release Model on Predicted Environmental Releases of Radionuclides ....... 50

6.3 Impact of Refreezing Heat Transfer Coefficient on Predicted Timing of Key Events ........ 51

6.4 Impact of Refreezing Heat Transfer on Predicted Environmental Releases of Radionuclides .. 52

6.5 Impact of Debris Ejection Model on Predicted Timing of Key Events ............... 53

6.6 Impact of Debris Ejection Model on Predicted Environmental Releases of Radionuclides ..... 54

6.7 Impact of Combination of Fuel Release Model and Debris Ejection Model Selection on

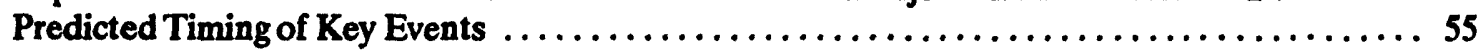

6.8 Impact of Combination of Fuel Release Model and Debris Ejection on Predicted Environmental Releases of Radionuclides ..................................... 56

6.9 Impact of Burn Propagation Parameter, $T_{\text {fro }}$ on Predicted Timing of Key Events .......... 57

6.10 Impact of Burn Propagation Parameter, $T_{\text {tro }}$ on Predicted Environmental Releases

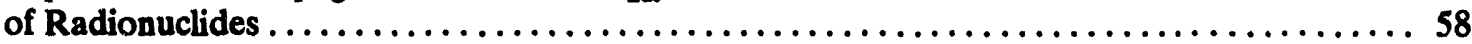

6.11 Impact of Maximum Allowable Timestep Size on Predicted Timing of Key Events ......... 59

6.12 Impact of Maximum Allowable Timestep Size on Predicted Environmental Releases

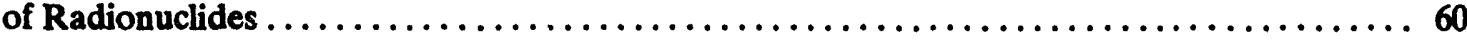

A.1 Comparison of Timing of Key Events Predicted by MELCOR 1.8BC and MELCOR 1.8CZ .. A-2 A.2 Comparison of Environmental Release of Source Terms Predicted by MELCOR 1.8BC

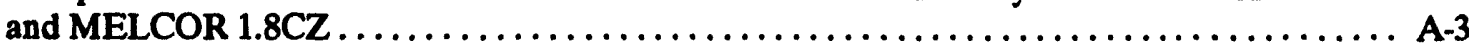

B.1 Impact of Maximum Allowable Timestep Size on Predicted Timing of Key Events (MELCOR Version 1.8DNX) ...................................... B-2

B.2 Impact of Maximum Allowable Timestep Size on Predicted Environmental Releases

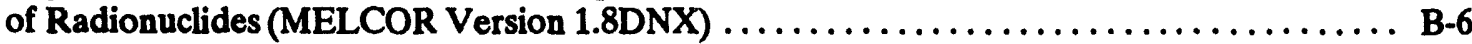

B.3 Core Debris Relocation and Lower Plenum Dryout Times for Various $\Delta \mathrm{t}_{\max }$

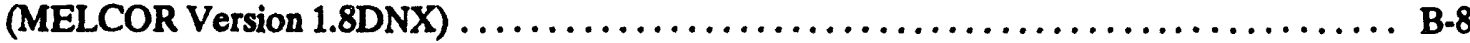

B.4 Impact of Maximum Allowable Timestep Size on Predicted Timing of Key Events

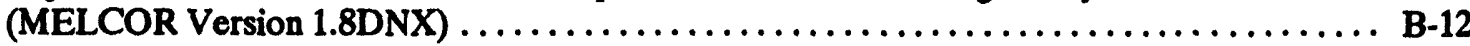

C.1 Impact of Maximum Allowable Timestep Size on Predicted Timing of Key Events (MELCOR Version 1.8.2) ....................................

C.2 Impact of Maximum Allowable Timestep Size on Predicted Environmental Releases of Radionuclides (MELCOR Version 1.8.2) ........................... C-4

C.3 Impact of Debris Fall Velocity in New Debris Quench Model on Predicted Timing of Key Events (MELCOR 1.8.2) .................................. C-23

C.4 Impact of Debris Fall Velocity in New Debris Quench Model on Predicted Environmental Releases of Radionuclides (MELCOR 1.8.2) ................. C-24

C.5 Predicted Timing of Key Events Using MELCOR LH Model and ORNL's BH

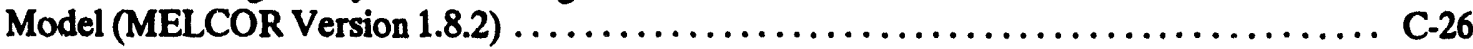




\section{Executive Summary}

MELCOR is a fully integrated severe accident analysis code that is being developed for the NRC by Sandia National Laboratories (SNL), to be used in probabilistic risk assessment (PRA) studies in order to address the perceived risk from a nuclear plant. Its development has focused on improved physical models, flexibility for future modification, and ease of use. MELCOR treats the complete accident sequence from the initiating event, through core uncovery, damage, fission product release and transport through the reactor coolant system and containment, and release to the environment. MELCOR is a second-generation source term code and it is designed to provide an improved severe accident/source term analysis capability relative to the older Source Term Code Package (STCP).

This report documents the results from MELCOR calculations of the Long-Term Station Blackout Accident Sequence with failure to depressurize, in a boiling water reactor (BWR) of the Mark I containment design, and presents comparisons with STCP calculations for the same sequence. The plant analyzed is Peach Bottom.

Accidents involving station blackout are the dominant sequences at Peach Bottom, accounting for almost 50 percent of total core damage frequency. Station blackout is defined as loss of all AC power. This is caused by loss of offsite power and subsequent failure of the diesel generators. Sequences that further assume common-cause failure of the station batteries are termed Short-Term Station Blackout. The remaining are the long-term station blackout sequences. Even though not the most dominant in terms of its contribution to total core damage frequency, the long-term station blackout sequence is considered the most likely to occur.

In the Long-Term Station Blackout scenario, loss of all off-site and on-site AC power leads to the loss of all active engineered safety features except the steam powered emergency core cooling systems. The latter, however, require DC power for operation and would fail when the station batteries are depleted, which has been estimated at six hours after the start of the accident. Following failure of the emergency core cooling system, the primary system inventory is boiled off through the relief valves by continued decay heat generation. This leads to core uncovery, heat up, clad oxidation, core degradation, relocation, and eventually, vessel failure. This will cause further pressurization of the drywell from steam and noncondensible gases, which may lead to containment failure. Multiple hydrogen burns can occur in the reactor building after the containment fails. STCP has calculated the transient out to 13.5 hours after core uncovery. Most of the MELCOR calculations have been carried out to between 15.0 and 16.7 hours after core uncovery. The results include the release of source terms to the environment, and hence, constitute a significant milestone in MELCOR application to plant simulation.

This report is intended to satisfy the requirements for Task 2 entitled "MELCOR Application to BWR Simulation" of the Project "MELCOR Benchmarking, Verification, and Applications" being performed for the U.S. Nuclear Regulatory Commission (NRC), by Brookhaven National Laboratory (BNL). The focus of this program is to provide an independent assessment of the modeling capabilities and limitations of MELCOR, and is complementary to the applications programs being carried out at Sandia National Laboratories and Oak Ridge National Laboratory (ORNL).

In addition to the MELCOR reference calculation, several sensitivity calculations were also performed and are presented in this report. These calculations consider the same sequence, but explore the impact of varying user-input modeling and timestep control parameters on the accident progression and release of source terms to the environment calculated by MELCOR. 
Most of the calculations documented here were performed in FY1990 using MELCOR Version 1.8BC. However, the Appendices also document the results of calculations performed in FY1991 using later released MELCOR versions 1.8CZ and 1.8DNX, and of more recent calculations performed in FY 1993 using the latest released MELCOR version 1.8.2. 


\section{Acknowledgements}

The author wishes to extend his appreciation to several individuals who have been very helpful throughout this project. In particular, he wishes to acknowledge the help and cooperation of the Development Staff at SNL for providing the untested input deck which served as the starting point of this investigation, for useful discussions, and for resolving code errors in a timely manner as they were uncovered at various stages of the calculation; W. T. Pratt, J. R. Lehner, and E. G. Cazzoli of BNL for many helpful discussions, and for reviewing the manuscript; R. Foulds, C. Tinkler, and F. Eltawila of the U. S. Nuclear Regulatory Commission for their continued support and guidance throughout this project.

A special note of thanks is due to Kara Roman and Alice Costantini for their excellent preparation of this manuscript. 


\section{Introduction}

\subsection{Background and Objectives}

This report documents the results from MELCOR (Version 1.8BC) calculations of the Long-Term Station Blackout Accident Sequence with failure to depressurize, in a boiling water reactor (BWR) of the Mark I containment design, and present comparisons with Source Term Code Package (STCP) calculations for the same sequence [1]. The plant analyzed is Peach Bottom.

This sequence assumes that batteries are available for 6 hours following loss of all power to the plant, which is the most likely core melt sequence, per draft NUREG-1150. The modeling of this sequence will test MELCOR's ability to simulate in-vessel melt progression leading to core slump, vessel failure, fission product release and retention, as well as ex-vessel behavior, over a long severe-accident transient. STCP has calculated the transient out to 13.5 hours after core uncovery. Most of the MELCOR calculations have been carried out to between 15.0 and 16.7 hours after core uncovery. The results include the release of source terms to the environment, and hence constitute a significant milestone in MELCOR application to plant simulation.

This report is intended to satisfy the requirements for Task 2 entitled "MELCOR Application to BWR Simulation" of the Project, "MELCOR Benchmarking, Verification, and Applications" being performed for the U. S. Nuclear Regulatory Commission (NRC), by Brookhaven National Laboratory (BNL). The focus of this program is to provide an independent assessment of the modeling capabilities and limitations of MELCOR, and is complementary to the applications programs being carried out at Sandia National Laboratories (SNL) and Oak Ridge National Laboratory (ORNL).

In addition to the MELCOR calculation mentioned above (henceforth termed reference calculation), several sensitivity calculations were also performed and are presented in this report. These calculations consider the same sequence, but explore the impact of varying user-input modeling and timestep control parameters on the accident progression and release of source terms to the environment calculated by MELCOR.

\subsection{MELCOR}

MELCOR is a fully integrated severe accident analysis code that is being developed for the NRC by SNL, to be used in probabilistic risk assessment (PRA) studies in order to address the perceived risk from a nuclear plant. Its development has focused on improved physical models, flexibility for future modification and ease of use. MELCOR treats the complete accident sequence from the initiating event, through core uncovery; damage, fission product release and transport through the reactor coolant system and containment, and release to the environment [2].

MELCOR is a second-generation source term code and it is designed to provide an improved severe accident/source term analysis capability relative to the older STCP [3]. MELCOR version 1.8.0 was released in March 1989. This version had the capabilities to model both BWR and PWR plants, the BWR capability being more mature than the PWR capability.

Subsequently, MELCOR 1.8BC was released as an interim version, and installed on BNL's VAX computer in November 1989. This version incorporates updates $1.8 \mathrm{AA}$ through $1.8 \mathrm{BC}$ in response to Defect Investigation Report (DIRs) submitted by users and SNL. The 1.8BC version has been used, together with a few patches to correct code errors, for most of the calculations presented in this report. Versions 1.8CZ, 1.8DC, and 1.8DN were released between April and September 1990, and installed at BNL. MELCOR 1.8DN was further updated to correct for mass inconsistencies in debris ejection to cavity. This corrected version was internally 
called MELCOR 1.8DNX. The latest released version of the code, MELCOR 1.8.2, was released to users in April 1993.

\subsection{Organization of Report}

Chapter 2 briefly describes the Mark I design. The Long-Term Station Blackout sequence is defined in Chapter 3. Chapter 4 describes the MELCOR model and some features of the simulation. Results of the MELCOR calculation and comparisons with STCP results are presented in Chapter 5. Major differences are identified. Chapter 6 describes several sensitivity calculations for the same sequence using MELCOR. A brief comparison of the accident progression and source term to the environment calculated by MELCOR $1.8 \mathrm{BC}$ and the latest version, i.e., $1.8 \mathrm{CZ}$ are included in appendix $\mathrm{A}$. Appendix $\mathrm{B}$ presents the results of calculations and findings from MELCOR 1.8DNX. Appendix C presents the results of additional calculations and findings from the latest released MELCOR version 1.8.2. 


\section{BWR Mark I Design}

There are 24 domestic BWR Mark I units, most of them employing the BWR-4 reactor design. The basic design characteristics of five of these plants are summarized in Table 2.1. The Mari I containment is the earliest standardized containment built for BWRs [4]. It has since been replaced in newer plants by the Mark II and III configurations. The oldest operating unit -Oyster Creek 1 in Oyster Creek, New Jersey - received its operating license in 1969. The newest is Hope Creek 1, in Salem, New Jersey, which started operating in 1986. The electrical output of the operating plants ranges from a low of $514 \mathrm{MWe}$ for the Vermont Yankee plant to a high of 1070 MWe at the Hope Creek plant. The two units of the Peach Bottom plant are located in York County, Pennsylvania. They are operated by the Philadelphia Electric Company, produce $1065 \mathrm{MWe}$ each, and have been in service since $1974[5,6]$.

\subsection{Reactor System}

The fuel for the reactor core consists of slightly enriched uranium-dioxide pellets contained in sealed Zircaloy-2 tubes. These fuel rods are assembled into individual fuel assemblies. Gross control of the core is achieved by movable, bottom-entry control rods. The control rods are of cruciform shape and are dispersed throughout the lattice of fuel assemblies. The rods are controlled by individual hydraulic systems.

The reactor vessel (see Figure 2.1) contains the core and supporting structure, the steam separators and dryers, the jet pumps, the control rod guide tubes, distribution lines for the feedwater, core spray, and standby liquid control, the incore instrumentation, and other components. The main connections to the vessel include the steam lines, the coolant recirculation lines, feedwater lines, control rod drive housings, and core standby cooling lines. The reactor vessel is designed and fabricated in accordance with applicable codes for a pressure of 1,250 psig. The nominal operating pressure is 1,020 psia in the steam space above the separators.

The reactor core is cooled by demineralized water which enters the lower portion of the core and boils as it flows upward around the fuel rods. The steam leaving the core is dried by steam separators and dryers located in the upper portion of the reactor vessel. The steam is then directed to the turbine through the main steam lines. Each steam line is provicied with two isolation valves in series, one on each side of the primary containment barrier. The reactor recirculation system pumps reactor coolant through the core to remove the energy generated in the fuel. This is accomplished by two recirculation loops external to the reactor vessel but inside the primary containment. Each loop has one motor-driven recirculation pump.

The reactor protection system (RPS) initiates a rapid, automatic shutdown (scram) of the reactor. This action is taken in time to prevent excessive fuel cladding temperatures and any nuclear system process barrier damage following abnormal operational transients. The RPS overrides all operator actions and process controls. When a scram is initiated by the RPS, the control rod drive system (CRDS) inserts the negative reactivity necessary to shut down the reactor. Each control rod is controlled individually by a hydraulic control unit. When a scram signal is received, high-pressure water from an accumulator for each rod forces each control rod rapidly into the core.

A pressure relief system, consisting of relief and safety valves mounted on the main steam lines, prevents excessive pressure inside the nuclear system following either abnormal operational transients or accidents.

\subsection{Primary Containment}

The primary containment consists of a drywell, shaped like an inverted light bulb, that encloses the reactor vessel, and its recirculation pump and piping, a toroidal pressure suppression chamber (wetwell), and a connecting vent system between the drywell and wetwell pool (see Figure 2.2). Pertinent design parameters are given in Table 2.1. The dimensions provided in this section are representative Peach Bottom values. Under 
accident conditions, valves in the main steam lines from the reactor to the turbine-generators would automatically close, and any steam escaping would be released entirely within the drywell. The resulting increase in drywell pressure would force the air-steam mixture in the drywell into the wetwell pool, where the steam would be completely condensed. Steam released through the relief valves of the automatic depressurization system also would be condensed in the wetwell pool.

The drywell is a steel pressure vessel with a spherical lower portion about $20 \mathrm{~m}$ in diameter and a cylindrical upper portion about $12 \mathrm{~m}$ in diameter. The overall height of the drywell is $\sim 35 \mathrm{~m}$. The entire weight of the reactor is supported by a reactor vessel support assembly which positions and transfers the weight of the reactor to the support pedestal. The concrete and steel support pedestal is constructed integrally with the reactor building foundation. The pedestal has one or two major doorway openings on opposite sides which extend down to the drywell floor.

The wetwell is a steel pressure vessel of toroidal shape, located below and surrounding the drywell. The

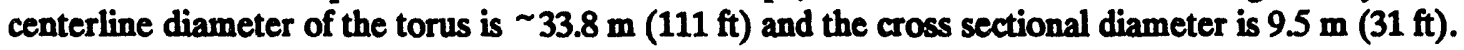

The drywell and wetwell are connected by a vent system which, under accident conditions, directs flow from the drywell into the suppression pool and distributes this flow uniformly around the pool. Eight circular vent pipes, each $2.06 \mathrm{~m}$ (6.75 ft) in diameter, connect the drywell to the wetwell. Jet deflectors are provided in the drywell at the entrance to each vent pipe. These vents are connected to a $1.45 \mathrm{~m}$ ( $4 \mathrm{ft}, 9 \mathrm{in}$ ) diameter vent header of toroidal shape, which is contained within the airspace of the wetwell. Ninety-six downcomer pipes, each $0.61 \mathrm{~m}$ (24 in.) diameter, project downward into the suppression pool, terminating $1.22 \mathrm{~m}$ (4 ft) below the surface of the pool. Vacuum breakers discharge from the wetwell atmosphere into the vent pipes to prevent the suppression pool pressure from exceeding the drywell pressure by more than 0.5 psi. The wetwell, which is located in a separate room in the reactor building basement (Figure 2.3), is accessible only through two normally closed manhole entrances with double testable seals and bolted covers. Steam can also be directed into the pool by separate lines from the safety/relief valves on the reactor's primary system. These valves serve to protect the primary system from excessive pressure and can also serve to reduce vessel pressure quickly.

In addition to serving as a heat sink for drywell blowdown following a loss-of-coolant accident, the suppression pool serves as a source of water for the HPCI, HPCS, RCIC, LPCS, and RHR systems as well as a heat sink for the SRV discharge and the HPCI and RCIC turbine exhausts.

Several types of piping and electrical penetrations, as well as personnel and equipment access hatches, penetrate the primary containment. The general design of the piping penetrations incorporate a penetration sleeve which passes from the reactor building through the shield wall concrete and projects into the gap region between the shield wall and the drywell liner. Guard pipes and expansion bellows are incorporated where necessary to allow for movement and protection of process lines. Personnel and equipment hatches incorporate double, testable seals to ensure containment integrity.

The Mark I primary containments are relatively small compared to PWR plants of similar power. Hence, to prevent a potential hydrogen burn during a core damage accident they are inerted to less than 4 percent by volume of oxygen.

\subsection{Secondary Containment}

The secondary containment or reactor building completely encloses the primary containment. One of its purposes is to minimize the ground-level release of airborne radioactive materials and provide for the controlled and elevated release of the building atmosphere via the Standby Gas Treatment System under accident conditions. 
In addition to the primary containment, the reactor building houses the refueling and reactor service areas, the new and spent fuel storage facilities and other reactor auxiliary and service equipment, including the Reactor Core Isolation Cooling System, Reactor Water Cleanup System, Standby Liquid Control System, Control Rod Drive Hydraulic System equipment, the emergency core cooling systems, and electrical components.

The normal ventilation system provides filtered air to the reactor building and then exhausts it through an elevated release. The ventilation system maintains the reactor building at a 0.25 -inch water negative internal pressure, thereby ensuring inleakage.

The reactor building substructure consists of poured-in-place reinforced concrete exterior walls (with no liner) that extend up to the refueling floor. The refueling room floor is also made of reinforced poured-in-place concrete. The superstructure of the reactor building above the refueling floor is structural steel. The refueling floor walls are covered with insulated metal siding. The reinforced concrete exterior walls and the structural steel for the superstructure are designed for tornado considerations and missile protection. Several floors supporting plant equipment are located within and attached to the secondary containment. Workmen present on these floors are shielded from radiation during normal plant operation by the concrete surrounding the drywell and the refueling pool located above the drywell closure cap.

Excessive reactor building-to-atmosphere pressure differentials are prevented by venting to the atmosphere through relief panels. Three sets of relief panels and a flow limiter prevent overpressurization of the secondary containment system. These consist of the main steam relief panels, the zone relief panels, the exterior siding panels, and the HPCI steam line flow limiter. Main steam ruptures would be vented to the turbine building through main steam relief panels. Zone relief panels vent the reactor building to the refueling floor. The exterior siding (blowout) panels vent the refueling floor to the atmosphere.

All entrances and exits to and from the reactor building are through double door personnel and equipment air locks. Each pair of access doors is equipped with weather-strip type rubber construction seals and is electrically interlocked so that only one of the pair may be opened at a time. 
BWR Mark I Design

Table 2.1 Domestic BWR Mark I Design Parameters [7]

\begin{tabular}{|c|c|c|c|c|}
\hline Parameter & $\begin{array}{l}\text { Peach Bottom } \\
\text { Units } 2 \text { and } 3 \\
\end{array}$ & Browns Ferry & $\begin{array}{r}\text { Vermont } \\
\text { Yankee }\end{array}$ & Cooper \\
\hline Rated Power (MWt) & 3293 & 3292 & 1593 & 2381 \\
\hline Reactor Vessel Material & \multicolumn{4}{|c|}{ Carbon Steel/Clad Stainless Steel } \\
\hline RV Design Press. (psia) & 1265 & 1265 & 1265 & 1265 \\
\hline RV Design Temp $\left({ }^{\circ} \mathrm{F}\right)$ & 575 & 575 & 575 & 575 \\
\hline No. Jet Pumps & 20 & 20 & 20 & 20 \\
\hline No. Main Steam Lines & 4 & 4 & 4 & 4 \\
\hline MSL Design Press. (psig) & 1115 & 1146 & 1146 & 1146 \\
\hline MSL Design Teinp. ( $\left.{ }^{\circ} \mathrm{F}\right)$ & 583 & 563 & 563 & 563 \\
\hline Drywell/Wetwell Design Press. (psig) & 56 & 56 & 56 & 56 \\
\hline Drywell/Wetwell Design Temp. ( $\left.{ }^{\circ} \mathrm{F}\right)$ & 281 & 281 & 281 & 281 \\
\hline Drywell Free Vol. $\left(\mathrm{ft}^{3}\right)$ incl. Vent Pipes & 175,800 & 159,000 & 134,000 & 145,430 \\
\hline Wetwell Free Vol. $\left(\mathrm{ft}^{\mathbf{3}}\right)$ & $\begin{array}{c}127,700 \text { to } \\
132,000\end{array}$ & 119,000 & 99,000 & 109,810 \\
\hline Wetwell Water Vol. $\left(\mathrm{ft}^{\mathbf{3}}\right)$ & $\begin{array}{r}122,900 \text { to } \\
127,300\end{array}$ & 135,000 & 78,000 & 87,660 \\
\hline Vent Pipe Submergence in Wetwell Pool (ft) & 4 & 4 & 4 & 4 \\
\hline $\begin{array}{l}\text { Containment Leak Rate (Weight\%/day) at } 56 \\
\text { psig and } 281^{\circ} \mathrm{F}\end{array}$ & 0.5 & 0.5 & 0.5 & 0.5 \\
\hline Secondary Containment (SC) Type & \multicolumn{4}{|c|}{ Controlled Leakage, Elevated (Stack) Release } \\
\hline SC Design Press. (psig) & 0.25 & 0.25 & 0.25 & 0.25 \\
\hline $\begin{array}{l}\text { SC Design Inleakage, } \% \text { free vol/day at } 0.25 \text { in } \\
\mathrm{H}_{2} \mathrm{O}\end{array}$ & 100 & 100 & 100 & 100 \\
\hline Stack Construction & $\begin{array}{r}\text { Reinforced } \\
\text { Concrete }\end{array}$ & $\begin{array}{r}\text { Reinforced } \\
\text { Concrete }\end{array}$ & Steel & Steel \\
\hline Stack Height (above ground) & $500 \mathrm{ft}$. & $600 \mathrm{ft}$. & $318 \mathrm{ft}$. & $328 \mathrm{ft}$. \\
\hline
\end{tabular}




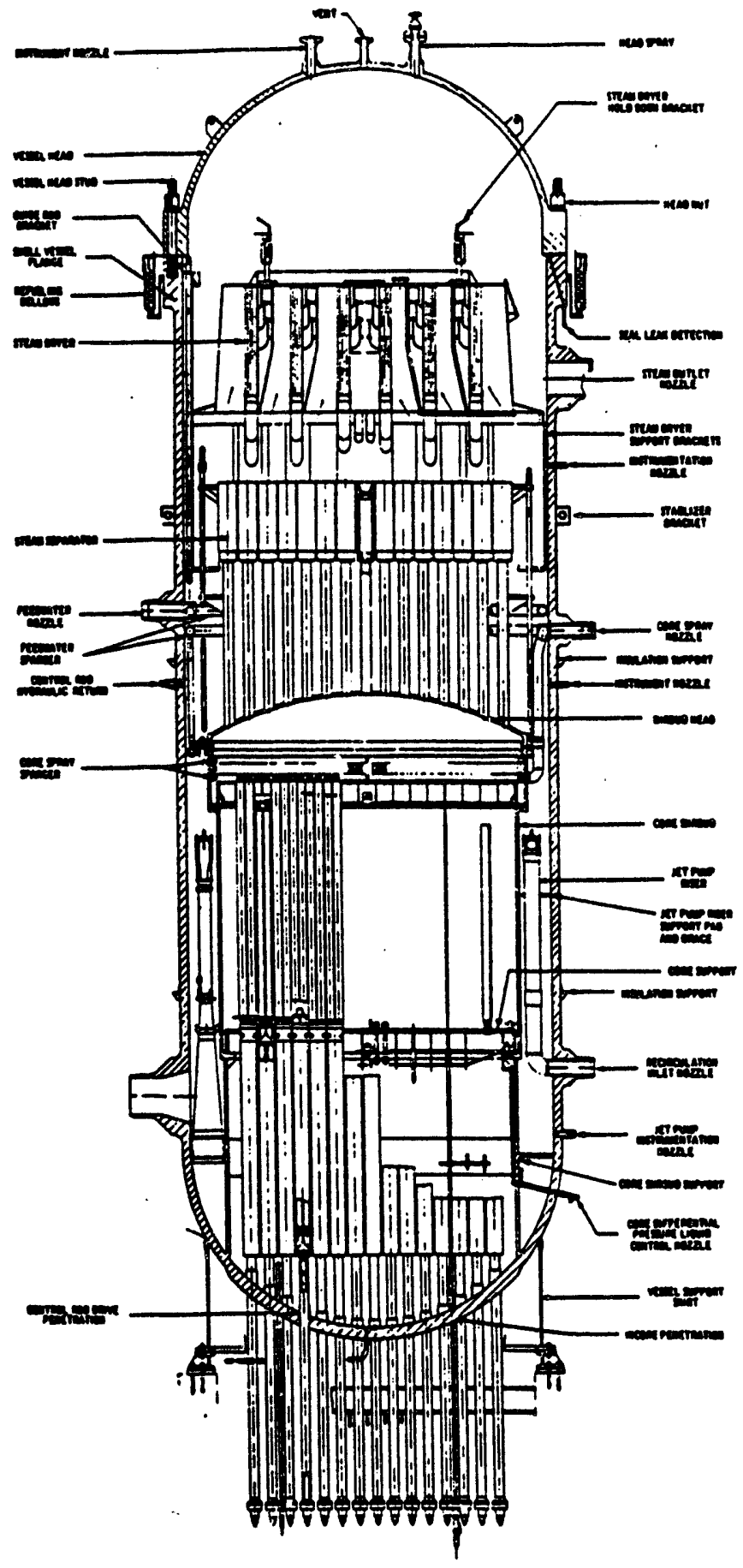

Figure 2.1 Reactor Vessel Schematic [7] 
BWR Mark I Design

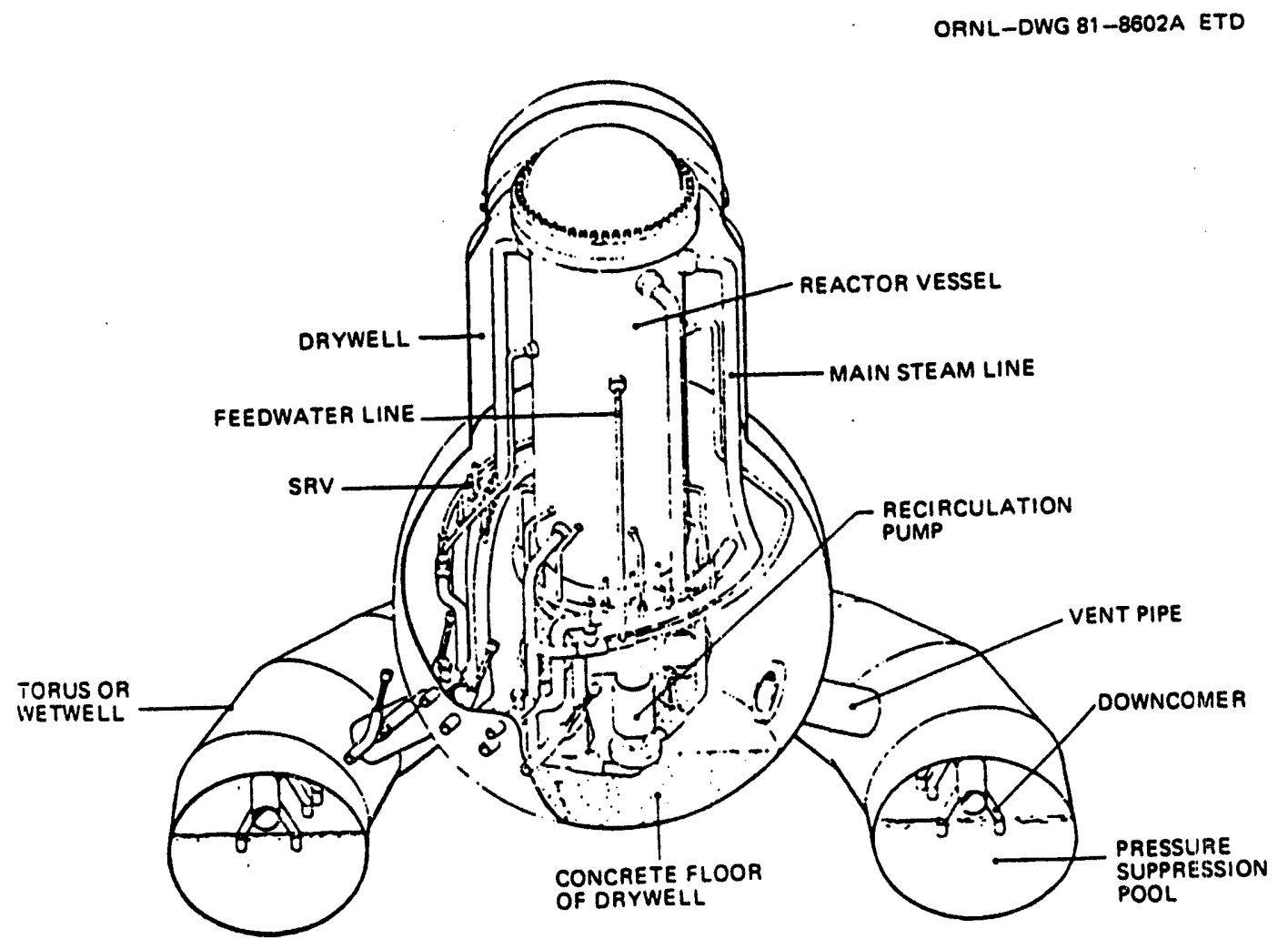

Figure 2.2 MK I Drywell/Torus Arrangement [6] 


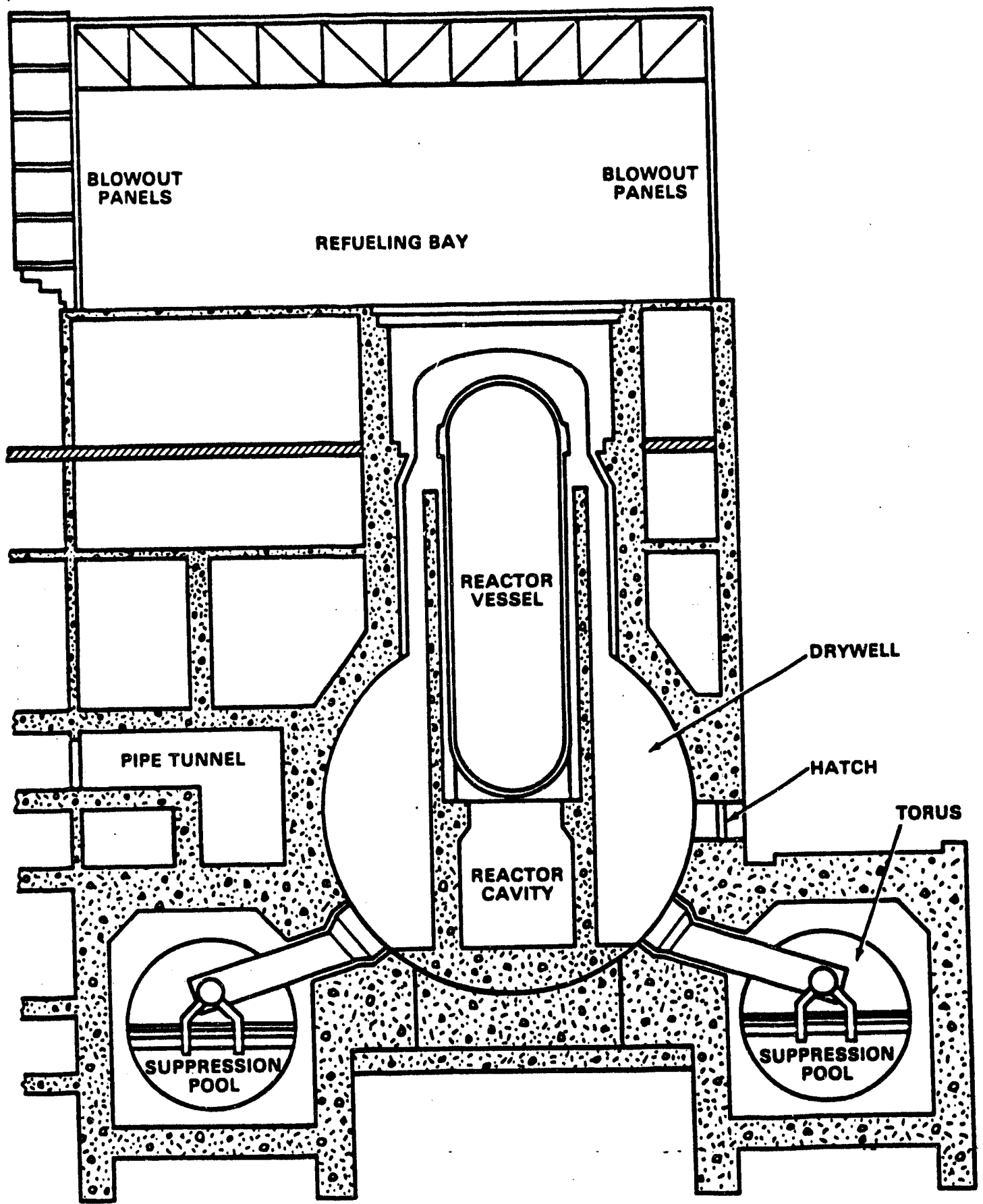

Figure 2.3 Schematic of the Containment Design for the Peach Bottom Plant [8] 


\section{Long-Term Station Blackout Sequence}

Accidents involving station blackout are the dominant sequences at Peach Bottom, accounting for almost 50 percent of total core damage frequency [9] (NUREG-1150). The number was even higher, 86 percent, based on the earlier Draft NUREG-1150 [10]. Station blackout is defined as loss of all AC power. This is caused by loss of offsite power and subsequent failure of the diesel generators. Sequences that further assume common-cause failure of the station batteries are termed Short-Term Station Blackout. The remaining are the long-term station blackout sequences. Even though not the most dominant in terms of its contribution to total core damage frequency, the long-term station blackout sequence is considered the most likely to occur [10].

In the Long-Term Station Blackout scenario, loss of ali off-site and on-site AC power leads to the loss of all active engineered safety features except the steam powered emergency core cooling systems. The latter, however, require DC power for operation and would fail when the station batteries are depleted, which has been estimated at six hours after the start of the accident. In such an event, core uncovery and melting would be expected to take place at high reactor coolant system pressure ( $>1000 \mathrm{psi}$ ) with the containment initially intact. Containment failure is possible at the time of reactor vessel failure or later in the sequence. Following failure of the emergency core cooling system at six hours into the accident, the primary system inventory is boiled off through the relief valves by continued decay heat generation. This leads to core uncovery, heat up, clad oxidation, core degradation, relocation, and, eventually, vessel failure. This will cause further pressurization of the drywell from steam and noncondensible gases, which may lead to containment failure. Multiple hydrogen burns can occur in the reactor building after the containment fails. 


\section{MELCOR Plant Model}

\subsection{Nodalization}

The MELCOR Peach Bottom model is a modified version of the untested input deck that was received from Sandia National Laboratory in 1988. It consists of 19 control volumes (6 for the Reactor Coolant System, 3 for the primary containment, 9 for the secondary containment, including refueling bay, and 1 for the environment); 33 flow paths (16 in the RCS and primary containment, and 17 in the secondary containment); and 66 heat structures (20 in the RCS and containment and the rest in the secondary containment). The reactor core is modeled with 33 core cells (i.e., 3 concentric radial rings at 11 axial levels). Levels 7 through 11 comprise the active core region, and levels 1 through 6 are the lower plenum including the core plate which is level 6 . Figures 4.1 and 4.2 show the MELCOR nodalization for the Peach Bottom plant and its reactor core, respectively'.

\subsection{Some Features of Simulation}

MELCOR either explicitly or parametrically models all key in-vessel and ex-vessel phenomena. In-vessel phenomena modeled include the thermal-hydraulic behavior of the reactor coolant system (RCS), fuel rod heatup, zircaloy oxidation, and hydrogen generation, core degradation, and lower head response. Fission product release, transport, deposition, and revaporization are also treated. Ex-vessel phenomena include core/concrete interactions, primary and secondary containment thermal-hydraulic and heat structure response, hydrogen burning and detonation, aerosol behavior, and the impact of engineered safety features (e.g., pools) on thermal-hydraulics and radionuclide transport.

Each cell may contain one or more types of components, including intact fuel, cladding, canister walls (for BWRs), other structures, such as control rods or guide tubes, and particulate debris, which may each contain several materials (e.g., $\mathrm{UO}_{2}$, Zircaloy, $\mathrm{ZrO}_{2}$ ). Oxidation and heat transfer by radiation, conduction, and convection are calculated separately for each component. A simple candling model treats the downward flow and refreezing of molten core materials, thereby forming layers of conglomerate debris on lower cell components which may lead to flow blockages and molten pools. Failure of core structures, such as the core plate as well as lower head heatup and failure followed by debris ejection, are treated by simple parametric models. For this simulation, the failure was triggered by a user-specified temperature corresponding to zero yield strength. Upon vessel failure, steam and gases are discharged through the opening. The default option allows solid debris and molten material to be discharged at a rate calculated from the pressure difference, flow area, and a loss coefficient.

Models for a broad spectrum of radionuclide behavior are included in MELCOR. By default, MELCOR uses the 15 classes recommended in the MELCOR Phenomena Assessment [11]. These default classes include two nonradioactive classes for bulk material aerosols (H2O and concrete) and are summarized in Table 4.1. The user may also create new classes to model the stoichiometric combination of elements in existing classes, such as Cs and I.

The release of fission products from fuel is modeled in MELCOR using either CORSOR or CORSOR-M [12]. Depending on user choice, these rate equations are then modified for the appropriate surface area to volume ratio of the fuel/debris as compared to the ratios represented in the experiments on which the models are based. If the clad is intact as determined by the gap release model discussed below, any released material is added to the gap inventory. This model is also used for the release of nonradioactive material. Release of radionuclide from the fuel-clad gap is modeled simplistically by a user-specified clad failure temperature (1173K for all calculations in this report). When the clad temperature in any cell in a given ring exceeds this

'S. Dingman, Private Communication, December 1988. 
clad failure temperature, or if the clad in a cell in this ring melts completely away, the entire gap inventory for that ring is instantaneously released. The elemental and compound forms of each class are both considered in the release model. For the $\mathrm{Cs}$ class, the elemental form is $\mathrm{Cs}$ but the compound form may be $\mathrm{CsOH}$. The difference in the elemental and compound molecular weights determines the amount of nonradioactive material that is added to the released mass. In the Cs class example, the mass of $\mathrm{OH}$ is added to the total mass of the Cs class.

Release during core-concrete reactions is treated by the VANESA [13] models. Aerosol dynamics involving agglomeration and deposition are calculated with the MAEROS [14] equations, while condensation and evaporation from aerosol and heat structure surfaces are calculated using the TRAP-MELT [15] models. 
Table 4.1 Material Classes in MELCOR [2]

\begin{tabular}{||l|c|l||}
\hline \multicolumn{1}{|c|}{ Class Name } & \multicolumn{1}{|c|}{ Representative } & \multicolumn{1}{|c|}{ Member Elements } \\
\hline 1. Noble Gases & $\mathrm{Xe}$ & $\mathrm{He}, \mathrm{Ne}, \mathrm{Ar}, \mathrm{Kr}, \mathrm{Xe}, \mathrm{Rn}, \mathrm{H}, \mathrm{N}$ \\
\hline 2. Alkali Metals & $\mathrm{Cs}$ & $\mathrm{Li}, \mathrm{Na}, \mathrm{K}, \mathrm{Rb}, \mathrm{Cs}, \mathrm{Fr}, \mathrm{Cu}$ \\
\hline 3. Alkaline Earths & $\mathrm{Ba}$ & $\mathrm{Be}, \mathrm{Mg}, \mathrm{Ca}, \mathrm{Sr}, \mathrm{Ba}, \mathrm{Ra}, \mathrm{Es}, \mathrm{Fm}$ \\
\hline 4. Halogens & $\mathrm{I}$ & $\mathrm{F}, \mathrm{Cl}, \mathrm{Br}, \mathrm{I}, \mathrm{At}$ \\
\hline 5. Chalcogens & $\mathrm{Te}$ & $\mathrm{O}, \mathrm{S}, \mathrm{Se}, \mathrm{Te}, \mathrm{Po}$ \\
\hline 6. Platinoids & $\mathrm{Ru}$ & $\mathrm{Ru}, \mathrm{Rh}, \mathrm{Pb}, \mathrm{Re}, \mathrm{Os}, \mathrm{Ir}, \mathrm{Pt}, \mathrm{Au}, \mathrm{Ni}$ \\
\hline 7. Early Transition Elements & $\mathrm{Mo}$ & $\mathrm{V}, \mathrm{Cr}, \mathrm{Fe}, \mathrm{Co}, \mathrm{Mn}, \mathrm{Nb}, \mathrm{Mo}, \mathrm{Tc}, \mathrm{Ta}, \mathrm{W}$ \\
\hline 8. Tetravalents & $\mathrm{Ce}$ & $\mathrm{Ti}, \mathrm{Zr}, \mathrm{Hf}, \mathrm{Ce}, \mathrm{Th}, \mathrm{Pa}, \mathrm{Np}, \mathrm{Pu}, \mathrm{C}$ \\
\hline 9. Trivalents & $\mathrm{La}$ & $\mathrm{Al}, \mathrm{Sc}, \mathrm{Y}, \mathrm{La}, \mathrm{Ac}, \mathrm{Pr}, \mathrm{Nd}, \mathrm{Pm}, \mathrm{Sm}, \mathrm{Eu}$, \\
& & $\mathrm{Gd}, \mathrm{Tb}, \mathrm{Dy}, \mathrm{Ho}, \mathrm{Er}, \mathrm{Tm}, \mathrm{Yb}, \mathrm{Lu}, \mathrm{Am}$, \\
\hline 10. Uranium & $\mathrm{Cm}, \mathrm{Bk}, \mathrm{Cr}$ \\
\hline 11. More Volatile Main Group & $\mathrm{U}$ \\
\hline 12. Less Volatile Main Group & $\mathrm{Cd}$ & $\mathrm{Cd}, \mathrm{Hg}, \mathrm{Zn}, \mathrm{As}, \mathrm{Sb}, \mathrm{Pb}, \mathrm{Tn}, \mathrm{Bi}$ \\
\hline 13. Boron & $\mathrm{Sn}$ & $\mathrm{Ga}, \mathrm{Ge}, \mathrm{In}, \mathrm{Sn}, \mathrm{Ag}$ \\
\hline 14. Water & $\mathrm{B}$ & $\mathrm{B}, \mathrm{Si}, \mathrm{P}$ \\
\hline 15. Concrete & $\mathrm{H} \mathrm{O}$ & $\mathrm{H}, \mathrm{O}$ \\
\hline
\end{tabular}




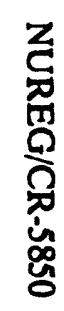

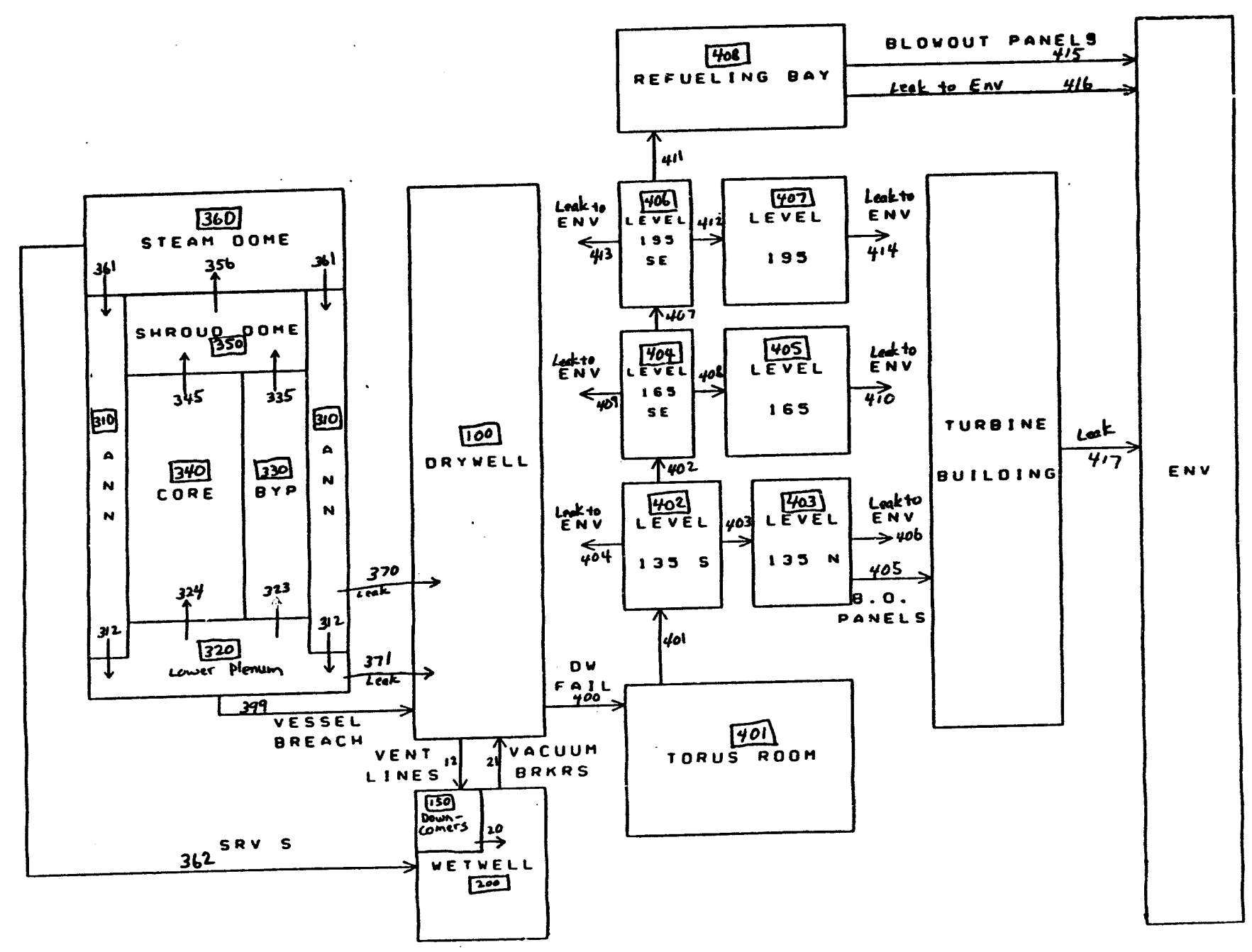

Figure 4.1 Peach Bottom Plant Nodalization for MELCOR 
MELCOR Plant Model

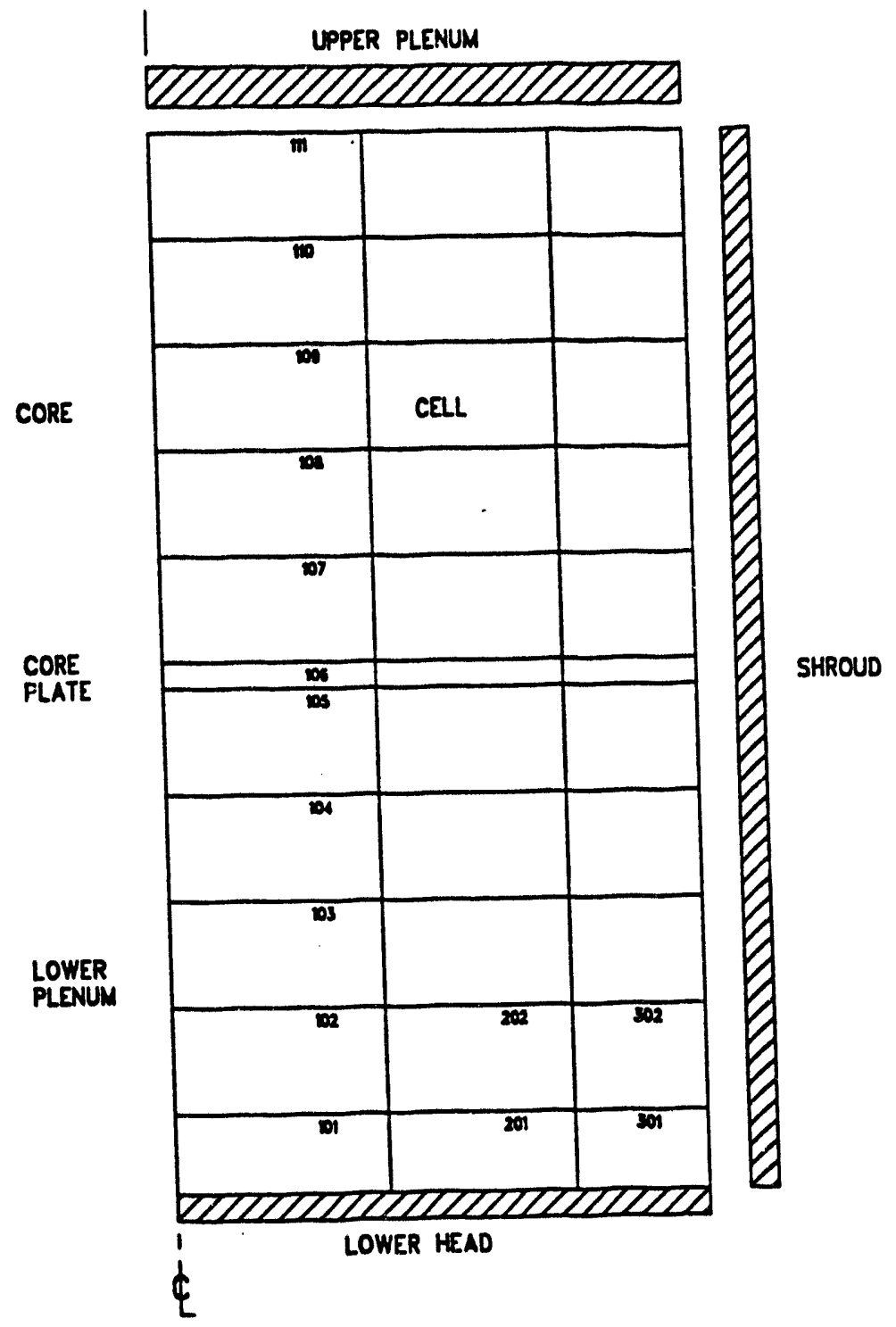

Figure $4: 2^{-}$Reactor Core Nodalization 


\section{Results and Comparisons with STCP}

In the base case MELCOR simulation of the station blackout scenario presented in this chapter, the maximum allowable timestep size ( $\Delta t_{\text {max }}$ ) is specified as 10 seconds, and the fuel release model selected is CORSOR with surface-to-volume ratio costections. The containment is assumed to fail in the drywell at a pressure of 9.1 bars ( 132 psia), which is consistent with the STCP assumption [1], and witi analysis of the steel shell performed by Ames Laboratory [15]. Computing time required for 60,000 seconds of problem time was 34,200 seconds (WARP $=1.75$ ) on a VAX 6340 computer.

\subsection{Key Events}

Table 5.1 summarizes the predicted timing of key events for the MELCOR and STCP [1] calculations, starting with core uncovery when the water level has dropped to the top of the active fuel. MELCOR predicts clad melting and relocation to start at about 99 minutes, with fuel melting following about 18 minutes later. STCP, on the other hand, does not distinguish between the different core components and calculates core melt to start at 114 minutes. MELCOR models the core in 3 radial rings and predicts partial core collapse to occur in the innermost ring at 154 minutes, while STCP calculates gross core collapse at 166.8 minutes. This can explain why the predicted dryout of the lower plenum occurs so much quicker for STCP. Vessel failure occurs in MELCOR at 274 minutes when the penetration in ring 1 fails, whereas STCP calculates gross lower head failure at 205 minutes. Note that following vessel breach, steam, non-condensible gases, and aerosols escape from the opening, while ejection of debris to the cavity occurs much later. This MELCOR-predicted time lag will greatly diminish the perceived probability of occurrence of DCH following this high pressure core melt sequence. MELCOR predicts drywell failure to occur at 7.1 hours, or $\mathbf{4 0}$ minutes later than the STCP calculation. Both codes predict deflagrations to occur in the reactor building and refueling bay, shortly after drywell failure.

\subsection{In-Vessel Behavior}

The response of important in-vessel parameters as calculated by MELCOR are shown in Figures 5.1 through 5.8 . Figure 5.1 shows the pressure response of the separator (CV350) and dryer (CV360) regions. The total pressure remains approximately constant due to the pressure-relieving operation of the SRV valves. However, the sharp downward pressure spike in steam partial pressures corresponds to a sharp positive pressure spike in the partial pressure of hydrogen which is produced from zircaloy oxidation. The sharp drop in total pressure starting at $\sim$ 16,500 seconds corresponds to vessel failure and subsequent depressurization of the vessel. Figure 5.2 shows the swollen liquid level in the core (CV340), bypass (CV330), annulus (CV310), and lower plenum (CV320), as a function of time. The rapid level drop in the lower plenum is seen to start at the same time that partial core collapse occurs in ring 1 ( $~ 9,250$ seconds), leading to eventual lower head dryout at 12,378 secords. Figures 5.3 and 5.4 show the cumulative flow of steam and hydrogen, respectively, through the SRV lines. The curves taper off and become flat for $t>16,5 \mathrm{~V} 0$ seconds, indicating that flow through these lines stops following vessel failure and depressurization.

Figures 5.5 through 5.8 show masses of zircaloy and fuel in various axial levels of the core in the imnermost ring. The sharp drop in mass at one level and a corresponding sharp mass increase at a lower level indicates downward relocation. MELCOR calculates the maximum temperature in the core to be $2500 \mathrm{~K}$, occurring in cell $111 \sim 7,000$ seconds after core uncovery. STCP predicts peak core temperature of $4100^{\circ} \mathrm{F}(\sim 2530 \mathrm{~K})$, occurring $\sim 6,850$ seconds after core uncovery.

Figure 5.9 shows the MELCOR-predicted cumulative in-vessel hydrogen production, which reaches in excess of $1300 \mathrm{~kg}$ by the end of the calculation, 60,000 seconds after core uncovery. There are no comparable results available with STCP. However, STCP calculates $25 \%$ zircaloy oxidation, to MELCOR's $46 \%$. 
STCP Results/Comparisons

\subsection{Ex-Vessel Behavior}

The primary containment pressure and temperature histories calculated by MELCOR are presented in Figures 5.10 through 5.15. In Figures 5.10 and 5.14, it can be seen that failure of the reactor vessel leads to rapid pressurization of both the drywell and wetwell, but the pressure stays below the nominal failure level. Containment failure is calculated to occur at about $\mathbf{4 2 6}$ minutes after core uncovery due to the combination of an elevated suppression pool temperature (Figure 5.15) and the buildup of non-condensible gas (Figure 5.16). The curves from STCP calculations show similar trends. Failure of the primary containment is followed shortly by several hydrogen burns in the reactor building and refueling bay. Their timings relative to containment failure are similar for both MELCOR and STCP. The predicted duration of deflagration is longer for MELCOR than for STCP. This is because the MELCOR plant model considers many compartments in the reactor building, with delays in burn propagation from one compartment to the next, while STCP models the entire reactor building as one volume.

Figure 5.19 shows the accumulation of metallic and oxidic debris in the cavity; Figure 5.20 shows the temperature history of various layers; and Figure 5.21 shows the cumulative masses of non-condensible gases released from core-concrete interactions.

\subsection{Fission Product Transport and Release to Environment}

The overall behavior of fission products and decay heat calculated by MELCOR is shown in Figures 5.22 through 5.25. Figure 5.22 shows the cumulative release of radioactive fission product mass from the fuel, along with deposited and released mass of aerosol and vapor components. Total released radioactive mass in-vessel is about $800 \mathrm{~kg}$. Figures 5.23 and 5.24 show the in-vessel and ex-vessel releases, respectively, of $\mathrm{CsOH}, \mathrm{Te}$, and CsI. Note that in $\mathrm{CsOH}$, only $\mathrm{Cs}$ is the radioactive component. It can be seen from the figures that the $\mathrm{Cs}$ and I releases occur predominantly in-vessel, whereas more of the Te release occurs ex-vessel. The cumulative in-vessel releases of $\mathrm{CsOH}(\sim 220 \mathrm{~kg})$ and CsI $(\sim 30 \mathrm{~kg})$ agree closely with STCP predictions. However, calculated Te releases are much lower than those using STCP. Figure 5.25 shows the location history of decay heat, both in- and ex-vessel. It can be seen that, with successive penetration failures in the three rings, the core decay heat drops in steps, as cavity decay heat increases in steps, while total decay heat decreases gradually with time.

Prior to vessel failure, fission products are transported to the suppression pool via the SRV lines, and thereafter, they enter the drywell directly. Following containment failure, fission products leak from the drywell into the reactor building, where they travel through the various compartments, and the refueling bay. Table 5.2 shows the fractional distribution of fission products in various regions of the plant and the environment at the end of the calculation from both MELCOR and STCP. Note that the Cs fractions for MELCOR in the table were obtained by weighted addition of $\mathrm{Cs}$ fractions in $\mathrm{CsI}$ form (Class 16) and in $\mathrm{CsOH}$ form (Class 2), as follows:

$$
f(C s)=0.92 f(\text { Class } 2)+0.08 f(\text { Class } 16)
$$

The coefficients, 0.92 and 0.08, in Eq. 5.1, were obtained from the distribution of Cs between the two classes. MELCOR-calculated I mass in the form of free Iodine (Class 4) was seen to be several orders of magnitude smaller than I mass in the form of CsI (Class 16). Hence, MELCOR-calculated I fractions in Table 5.1 were assumed equal to the fractions of CsI.

A comparison of environmental releases between MELCOR and STCP reveals significant differences, with MELCOR predicting much lower release fractions of $\mathrm{Te}, \mathrm{Sr}, \mathrm{La}, \mathrm{Ce}$, and $\mathrm{Ba}$, and $\mathrm{STCP}$ predicting lower release fractions of $\mathrm{I}, \mathrm{Cs}$, and $\mathrm{Ru}$. The higher release fractions of $I$ and $\mathrm{Cs}$ calculated by MELCOR can be attributed to their revaporization from the RCS. This phenomenon is not modeled in STCP. The lower Te, Sr, and Ba 
STCP Results/Comparisons

releases calculated by MELCOR may be because, whereas in STCP, the entire core falls into the cavity following vessel failure, MELCOR calculates debris ejection into the cavity that is staggered over a much longer period of time, based on successive penetration failures in the three rings. This leaves a larger fraction of the fission products in the cavity. 
Table 5.1 MELCOR and STCP-Predicted Timing of Key Events

\begin{tabular}{|l|c|c|}
\hline \multirow{2}{*}{ Key Event } & \multicolumn{2}{c|}{ Time (min) } \\
\cline { 2 - 3 } & MTrCOR & STCP \\
\hline Core uncovery & 0.0 & 0.0 \\
\hline Start zircaloy oxidation & 76.0 & \\
\hline First gap release of fission products & 76.8 & \\
\hline Start melt and relocation & 117.0 & 114.0 \\
\hline Core collapse & 154.4 & 166.8 \\
& (partial) & \\
\hline Lower plenum dryout & ring 1 & 176.3 \\
\hline Vessel failure & 206.3 & 205.0 \\
\hline Reactor vessel depressurized & 274.0 & \\
\hline Start debris ejection to cavity & 275.1 & 205.1 \\
\hline Drywell failure & 341.2 & 386.0 \\
\hline Start deflagrations in reactor building & 426.0 & 386.5 \\
\hline End deflagrations in reactor building & 426.4 & 386.9 \\
\hline Start deflagrations in refueling bay & 427.6 & 390.6 \\
\hline End deflagrations in refueling bay & 429.4 & 390.7 \\
\hline
\end{tabular}


Table 5.2 Fractional Distribution of Fission Products by Group in Plant and Environment

\begin{tabular}{|c|c|c|c|c|c|c|c|c|c|c|c|c|c|c|}
\hline \multirow[t]{2}{*}{ Speciee } & \multicolumn{2}{|c|}{ RCS } & \multicolumn{2}{|c|}{ Woumell } & \multicolumn{2}{|c|}{ Drymell } & \multicolumn{2}{|c|}{ Conity } & \multicolumn{2}{|c|}{ Rescetor Budilitims } & \multicolumn{2}{|c|}{$\begin{array}{c}\text { Rolbuling } \\
\text { Byy }\end{array}$} & \multicolumn{2}{|c|}{ Environmeent } \\
\hline & Mercor & stce & MaELOR & sTce & Mricon & stce & Mincon & stce & MRICOR & sTCP & Macon & stce & Mrescor & STCP \\
\hline 1 & 0.000 & 067 & Q.146 & 0.23 & 0.325 & 78B-OL & $\infty$ & 00 & $3.438-02$ & $420-08$ & 5,60100 & SAgeds & SSGE-02 & 7.8E-03 \\
\hline a & 0.334 & 0.74 & 0.14 & 0.14 & 0301 & $\cos -00$ & 00 & $\infty$ & $436 B-02$ & $498-\infty$ & 2.APE-08 & 622804 & 0.164 & $9.00-\infty 3$ \\
\hline To & 2000 & ass & $1.138-08$ & $3.68-08$ & 0.100 & $738-08$ & 0.297 & $a \times 3$ & $3018-02$ & a.19 & 1018R & $1.1 \mathrm{E}-\mathrm{en}$ & $1.768-00$ & 0.10 \\
\hline st & $3.28 R, 0 R$ & $9.7 \mathrm{~B}-\mathrm{A}$ & 2,28803 & 2980a & sesenen & a.31 & $0 . x$ & 0.16 & $400-02$ & $a x$ & 1.12300 & $1.7 B-\infty$ & A.13E-0 & a.21 \\
\hline $\mathbf{R u}$ & SSIB-DO & $1.3 \mathrm{E}-06$ & 200304 & $3.3 \mathrm{E}-01$ & $2673-04$ & $1.18-0$ & a.9se & 10 & $3.61 \mathrm{E} 04$ & 5xe-0 & $7.19 \mathrm{BES}$ & stens & seseos & $3.22-07$ \\
\hline $\mathbf{L}$ & $438-6$ & $138-09$ & 150800 & A.1E-6B & 7.40808 & $123-0$ & a.sen & ons & $28 \mathrm{~B}-0 \mathrm{~B}$ & $2 A B a$ & 10300 & $1.08-\infty 8$ & 8.23E-04 & $1.78-02$ \\
\hline co & 127200 & $\infty$ & $60058-06$ & $5.38-06$ & 7AB-15 & 18B-en & 0.096 & 0.91 & 7osedos & $3 \operatorname{seg} 0$ & 1,60806 & $2280-18$ & 1.40806 & 20802 \\
\hline Ba & $5 . x \in E-\infty$ & $1 . x B-x$ & $9, \sec -10$ & $5.28-02$ & 8.40800 & 0.16 & $a x$ & 0.38 & Aceser & $a n$ & $1.12=02$ & $1.38-12$ & A13E- -2 & 0.15 \\
\hline
\end{tabular}




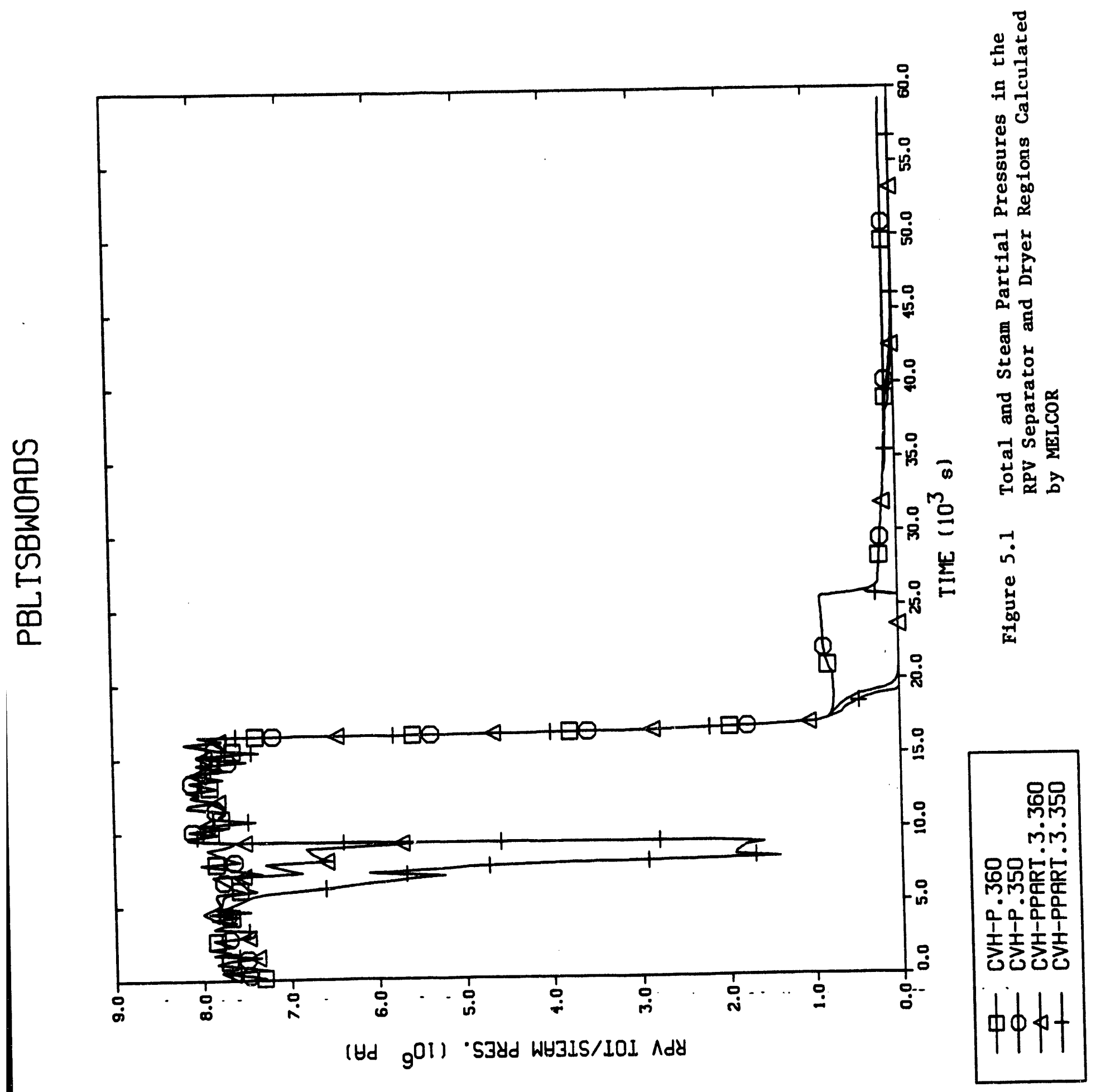




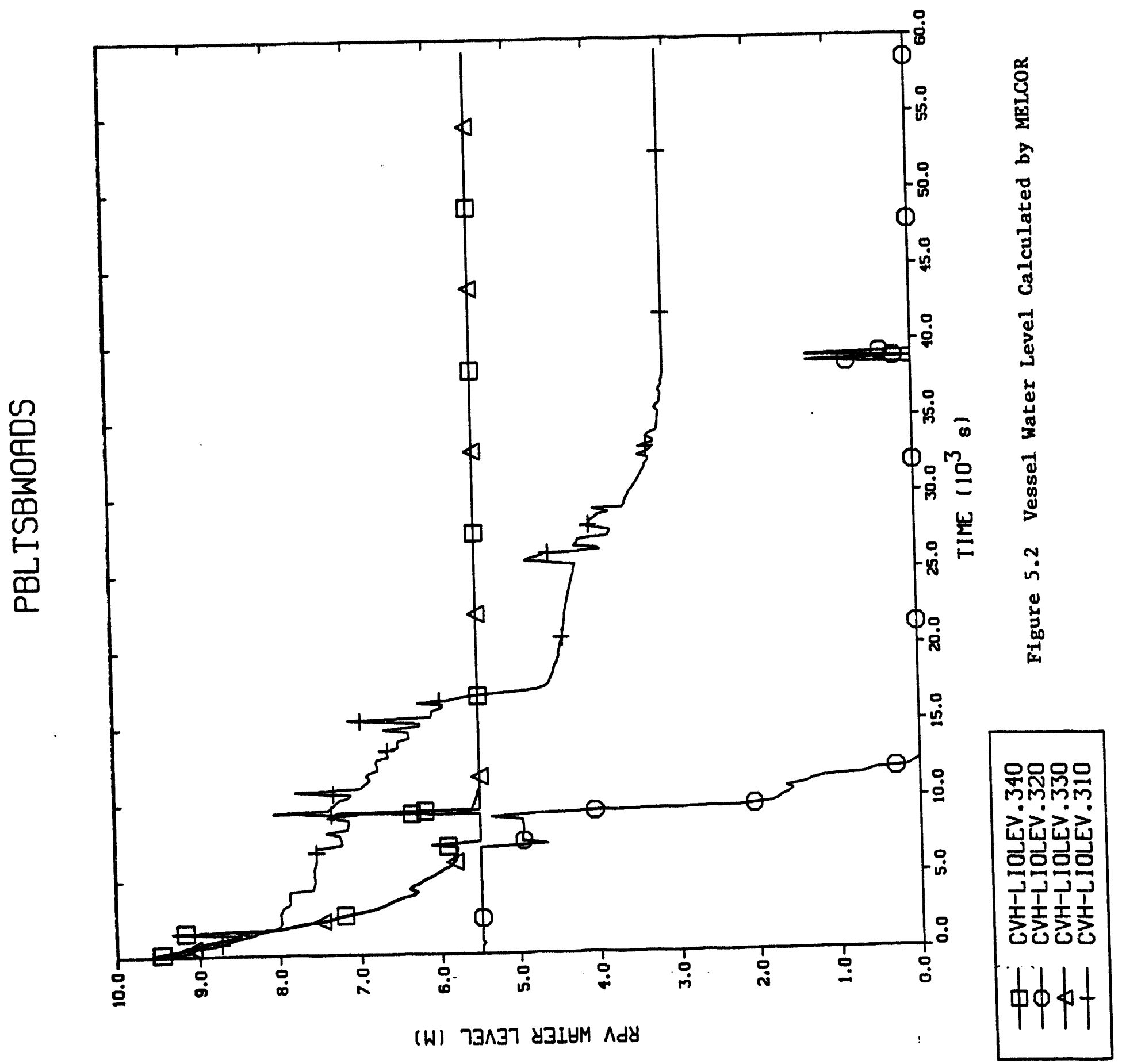


PBLTSBWOADS

W

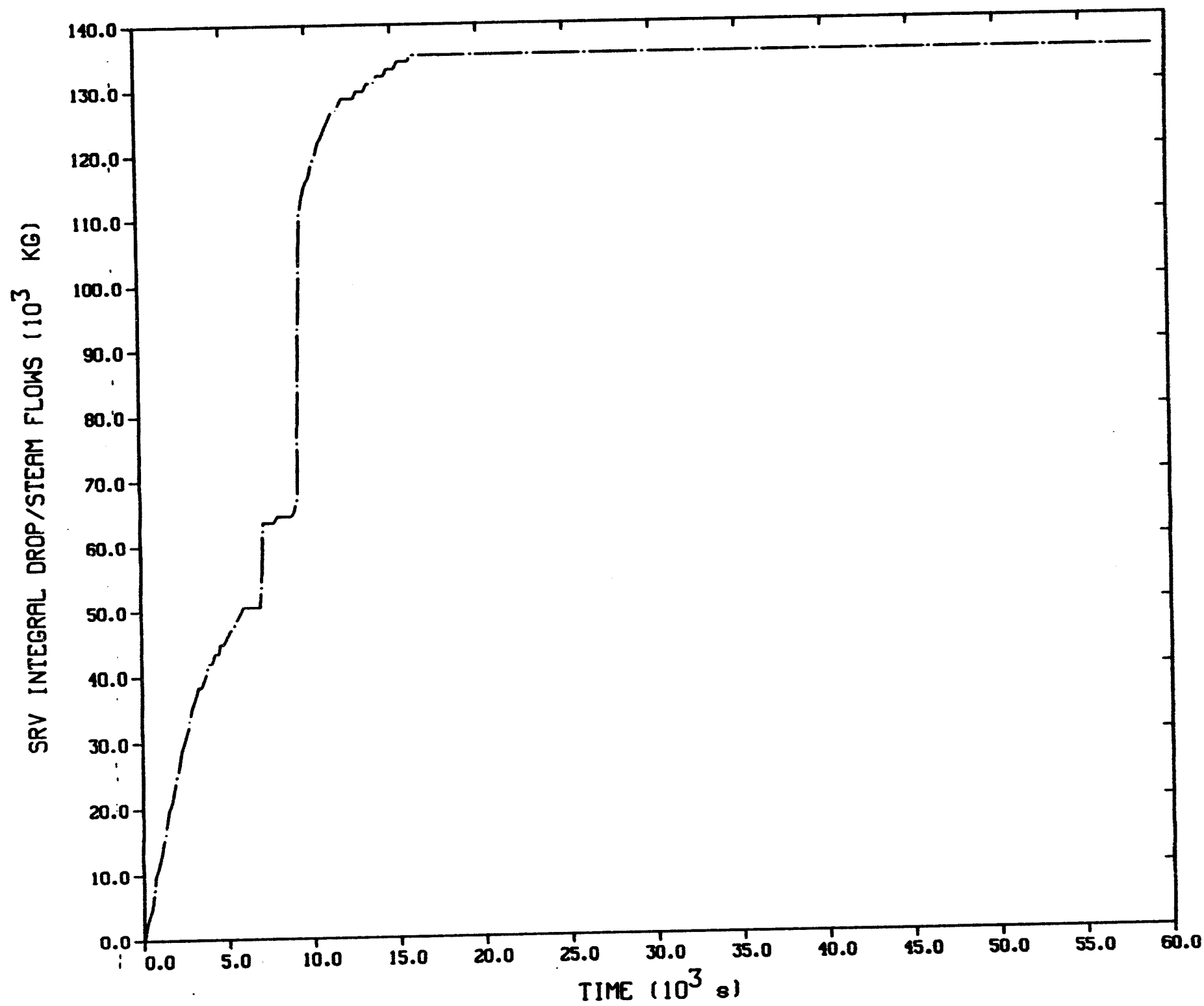

MEL-DROPLETS

Figure 5.3

MELCOR-Calculated Cumulative Steam Flow Through the SRV Line 


\section{PBLTSBWOADS}

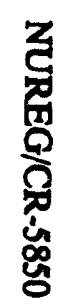

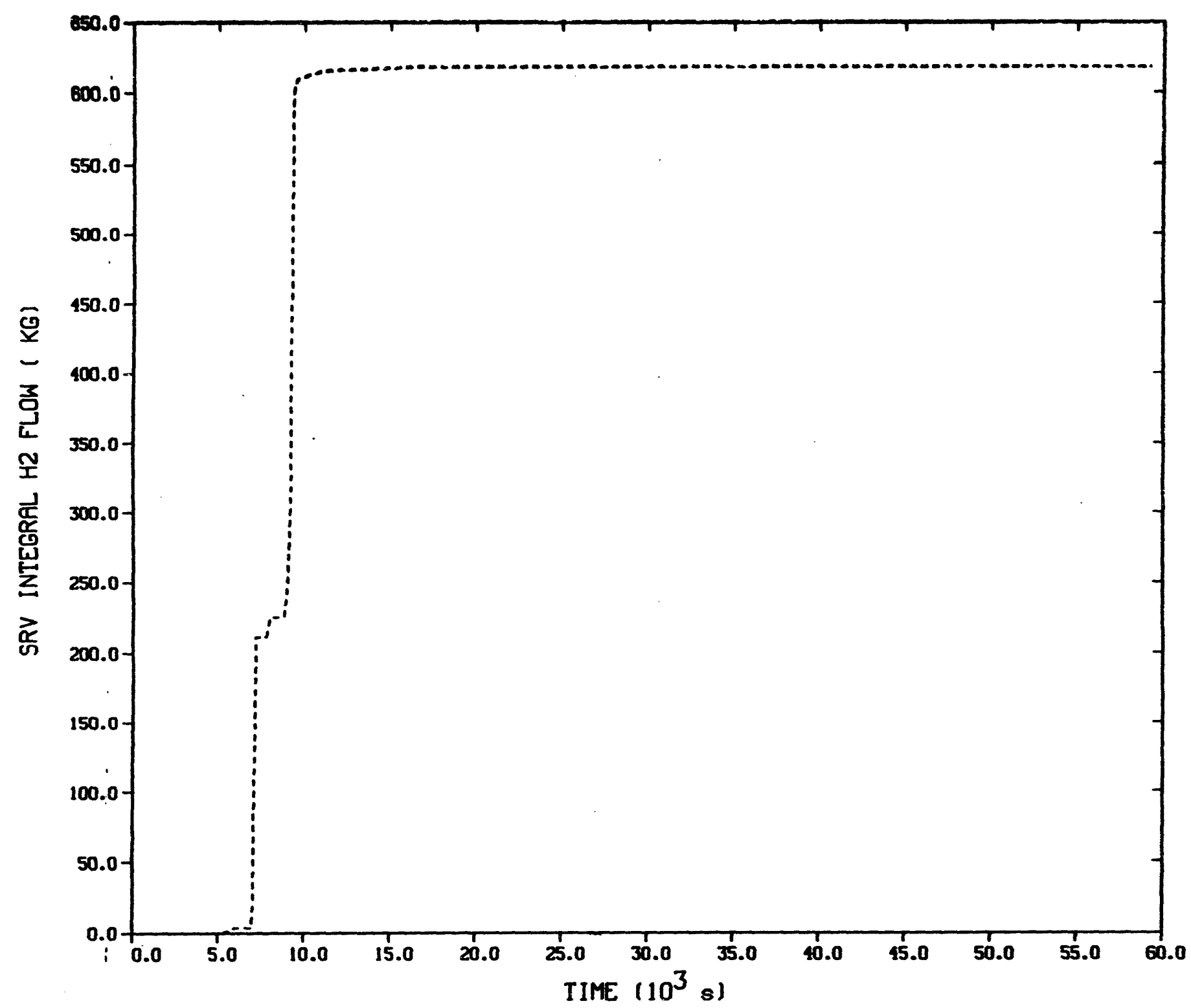




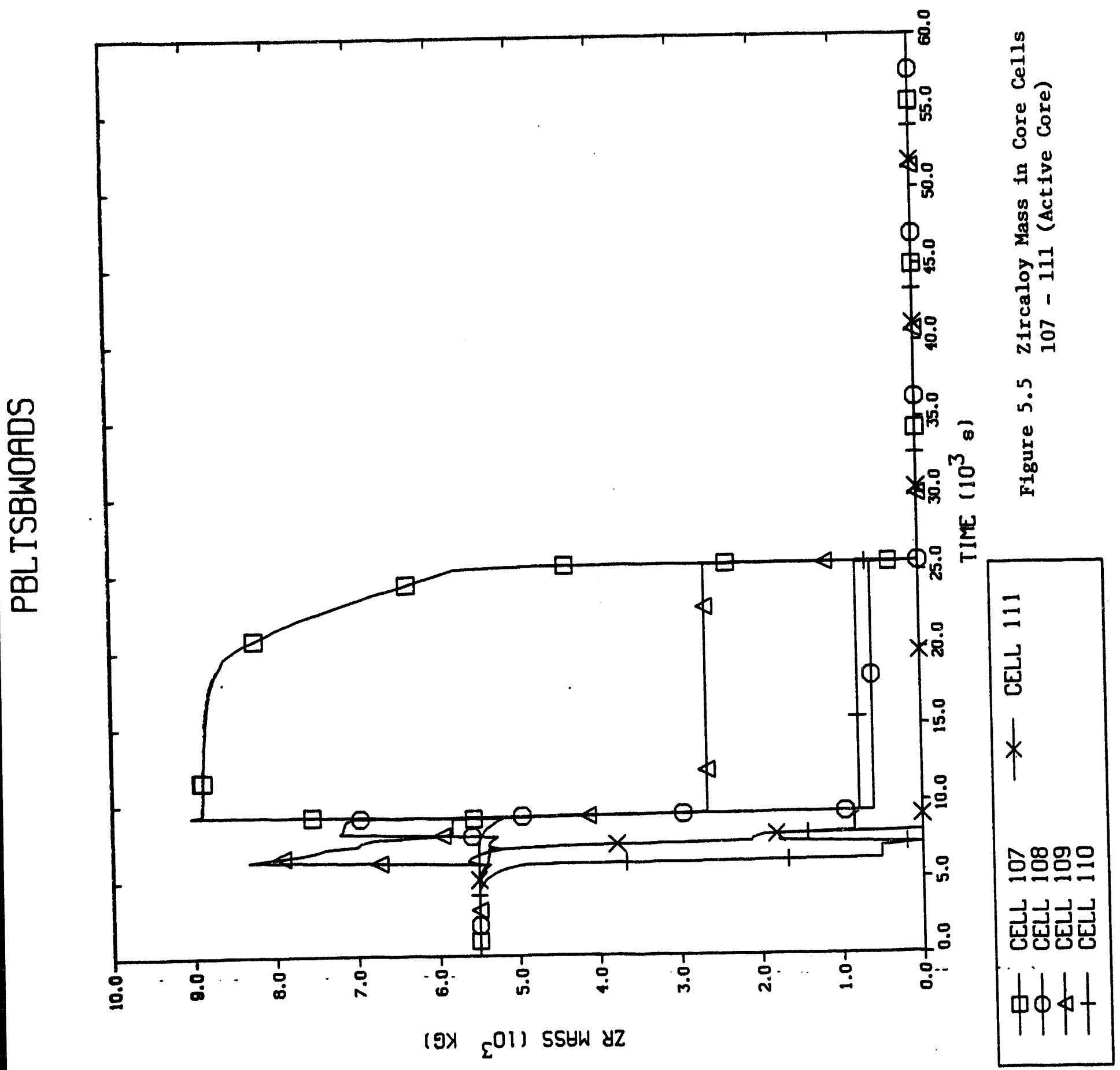




\section{PBLTSBWOADS}

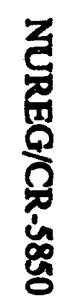

న

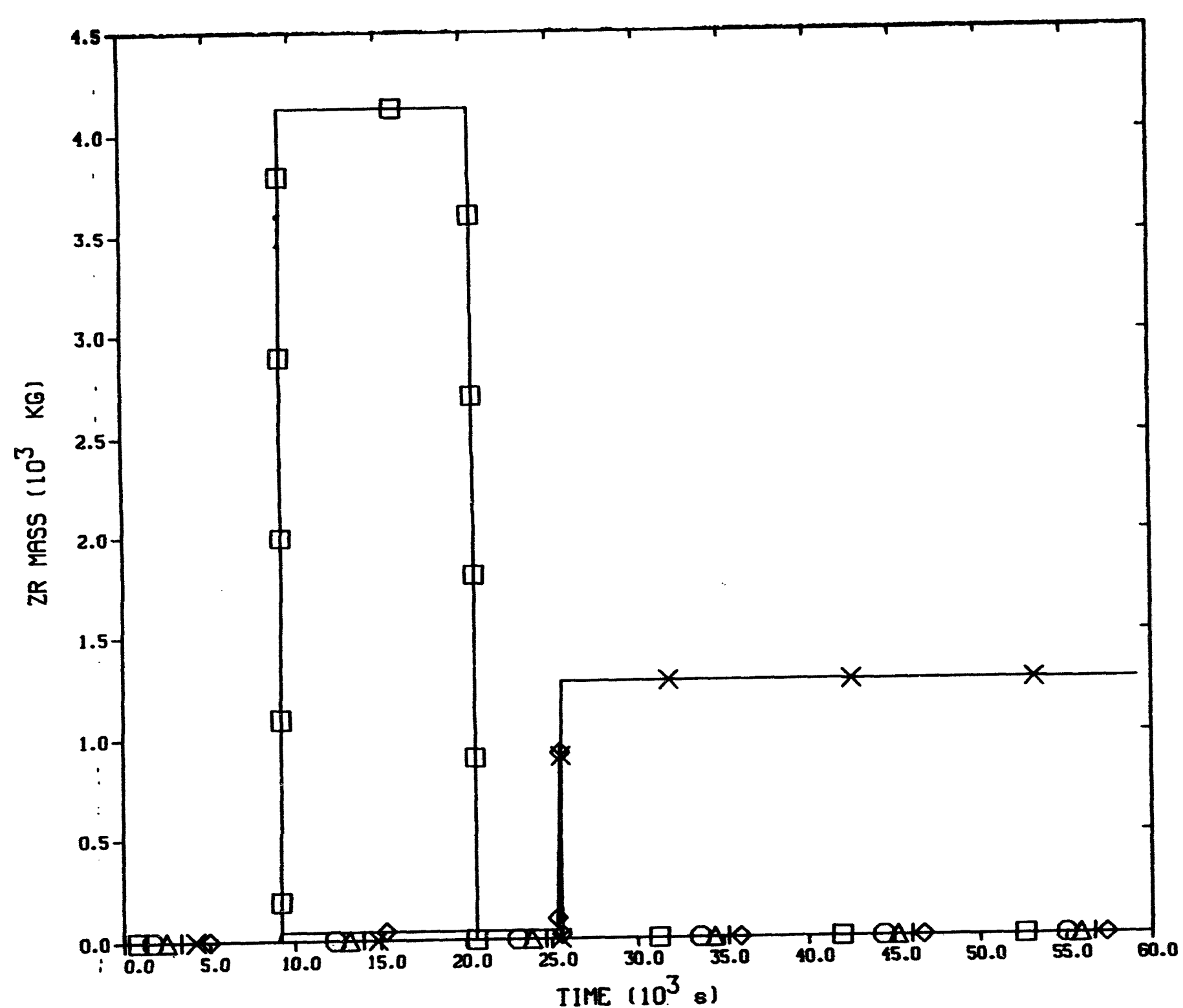

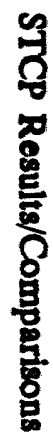

$$
\begin{aligned}
& \text { 田 CELL } 101 \rightarrow \text { CELL } 105 \\
& \begin{array}{l}
- \\
\triangle
\end{array} \text { CELL } 103
\end{aligned}
$$

Figure 5.6 Zircaloy Mass in Core Cells 101 - 106 (Lower Plenum) 


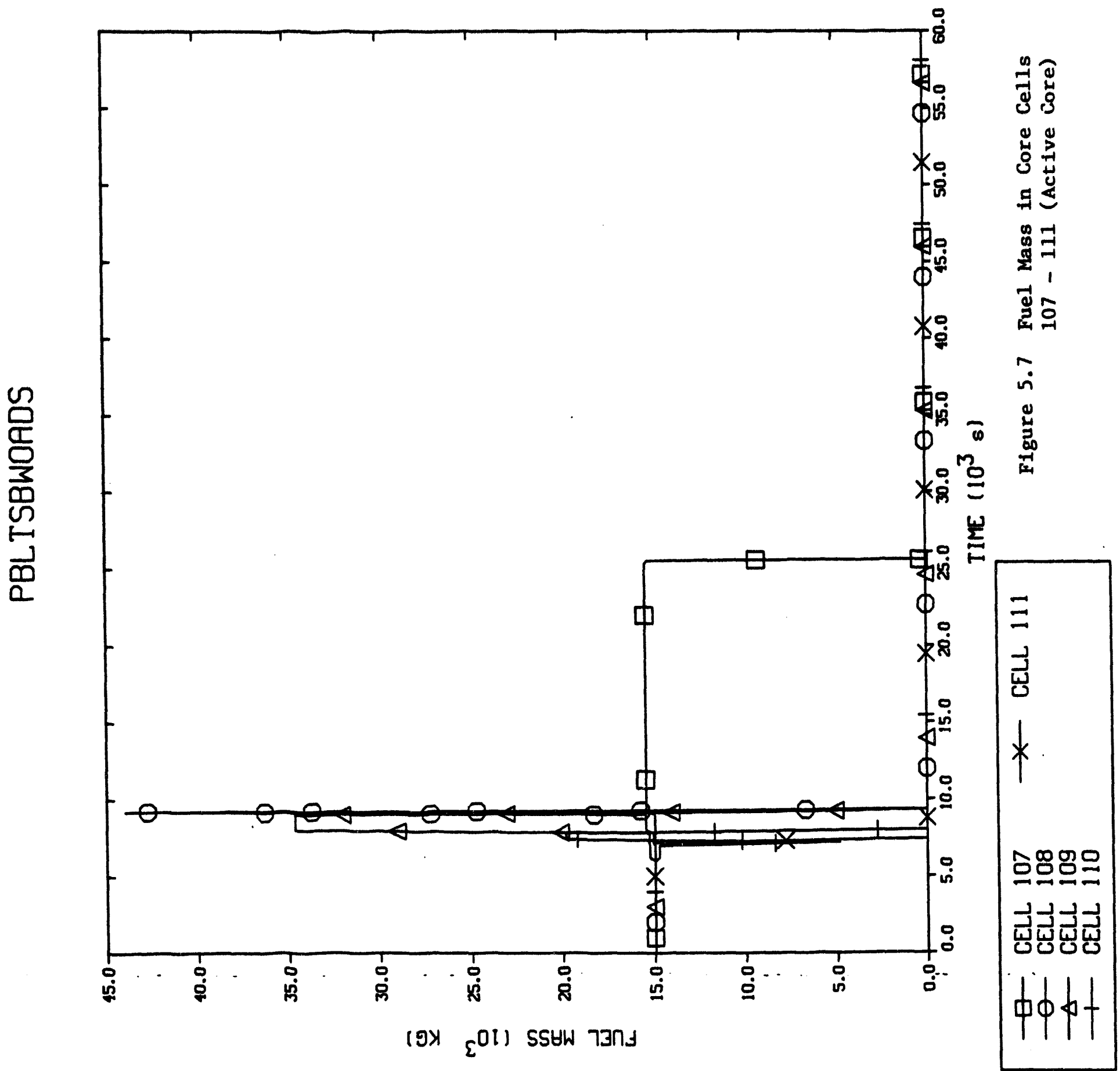




\section{PBLTSBWOADS}

忌

స

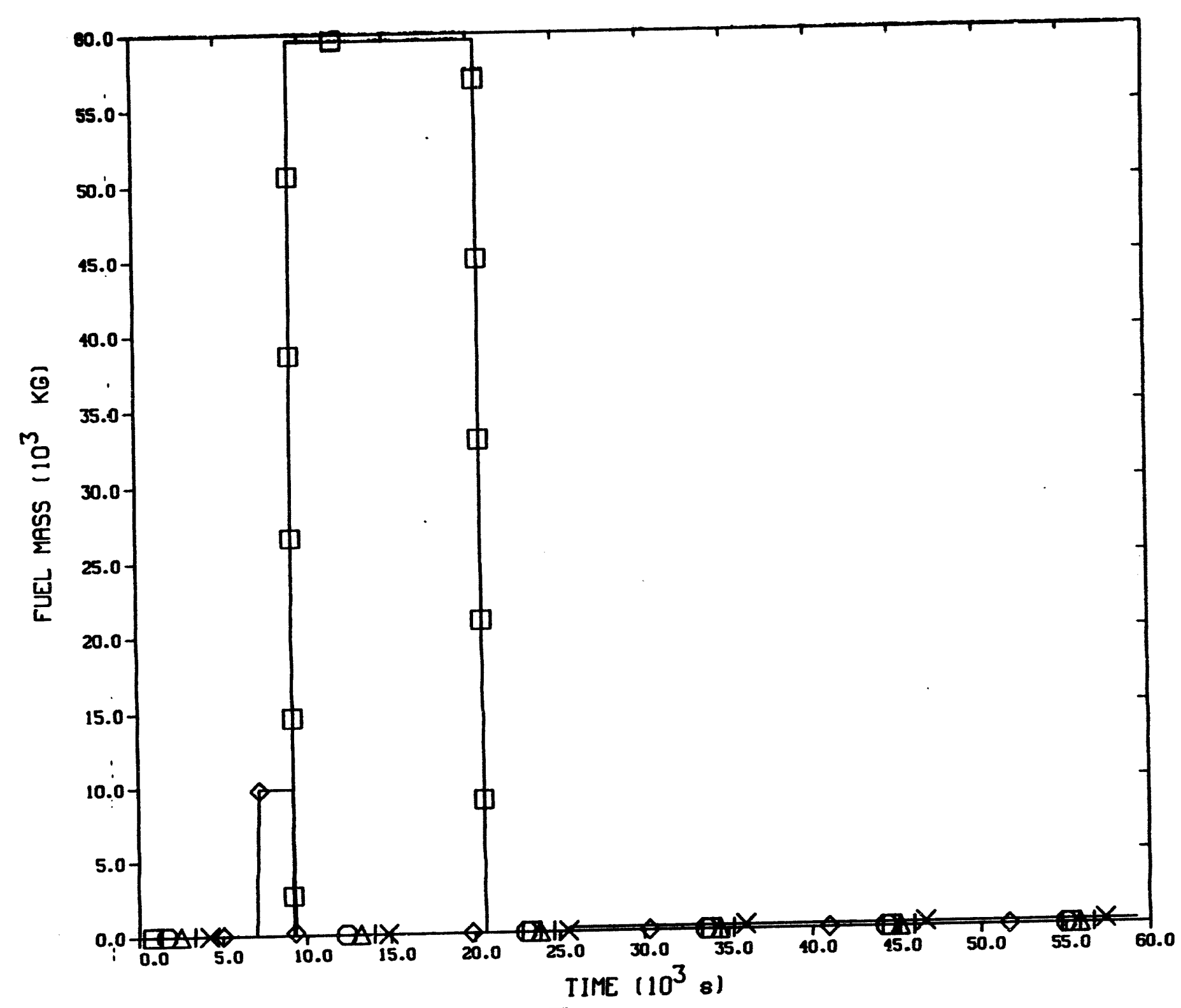

曰. CELL $101 \quad *$ CELL 105

$\theta-$ CELL 102 CELL 106

$\triangle$ CELL 103

+ CELL 104
Figure 5.8 Fuel Mass in Core Cells 101 - 106 (Lower P1enum) 


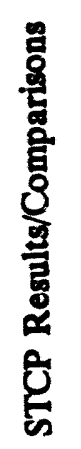

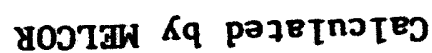

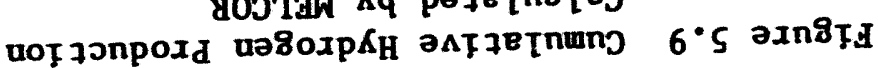

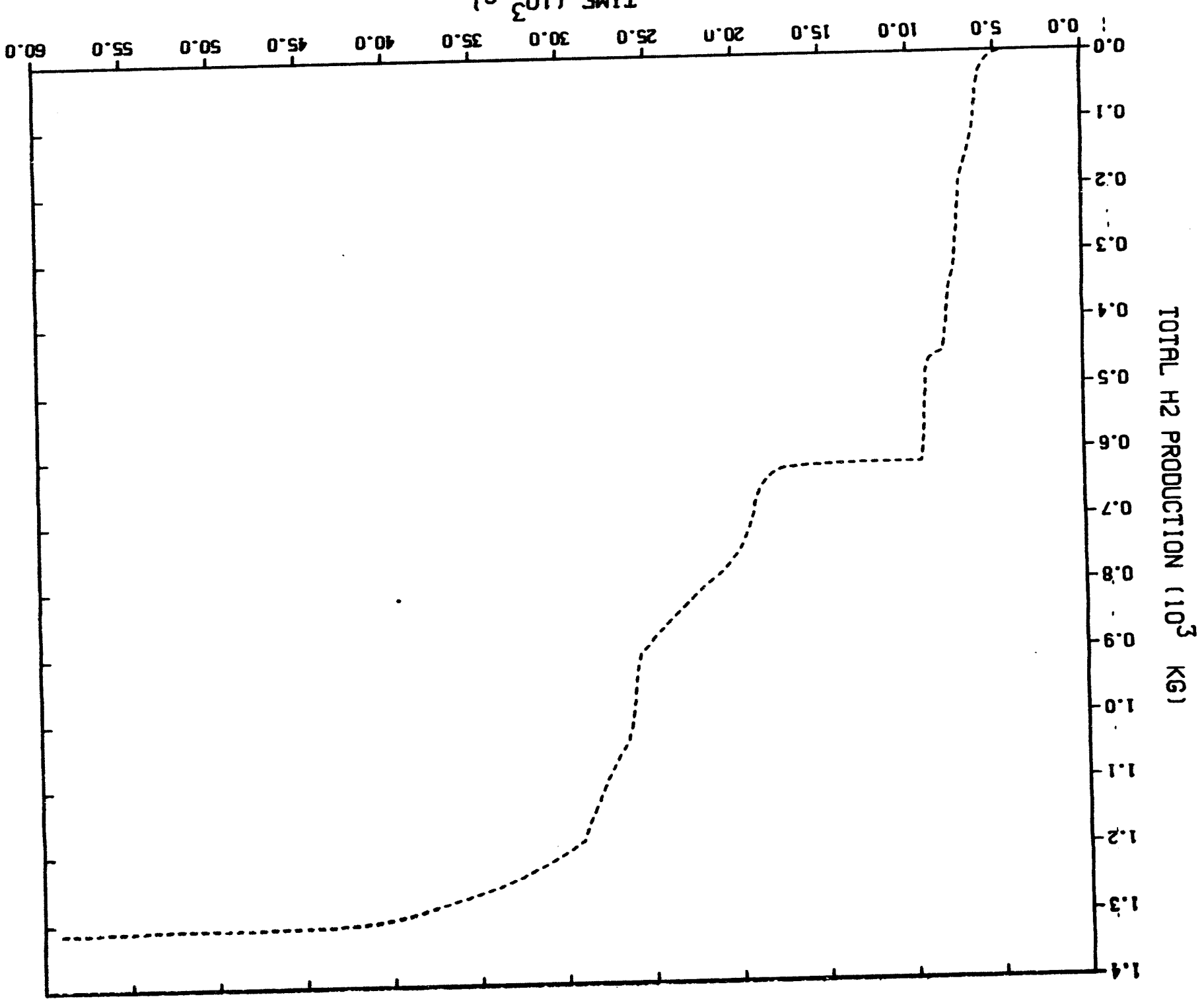


STCP Results/Comparisons

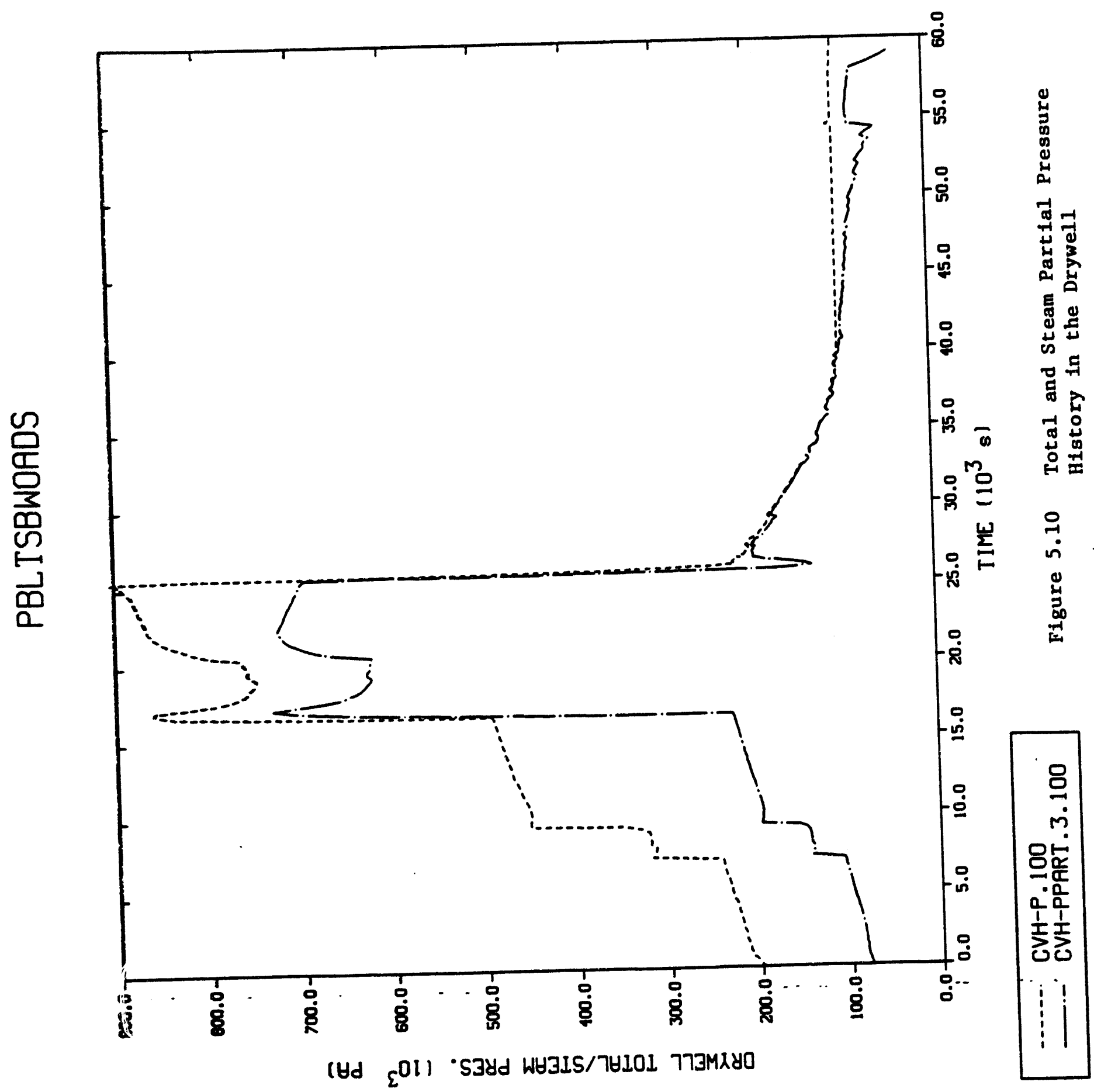




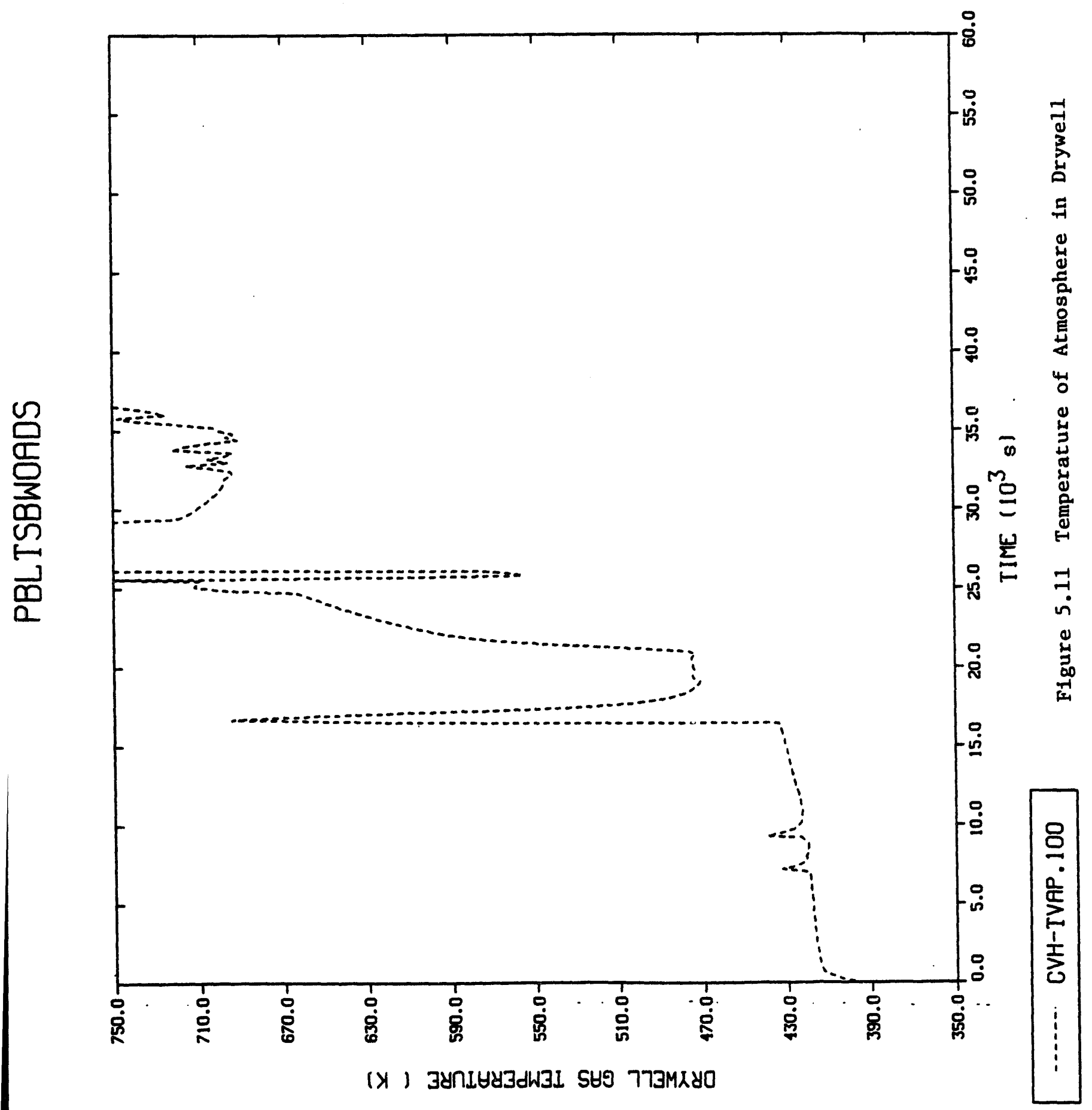




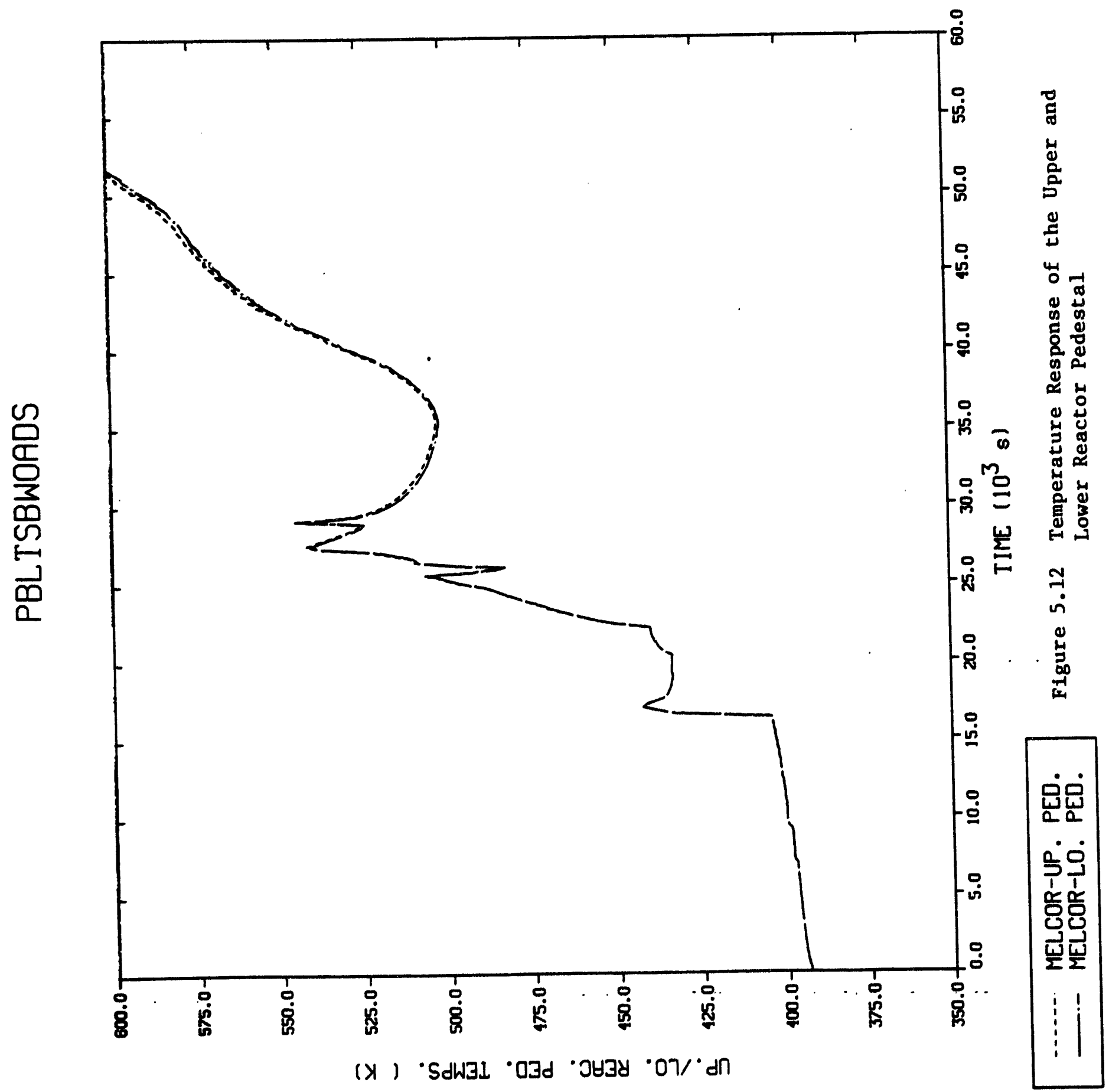




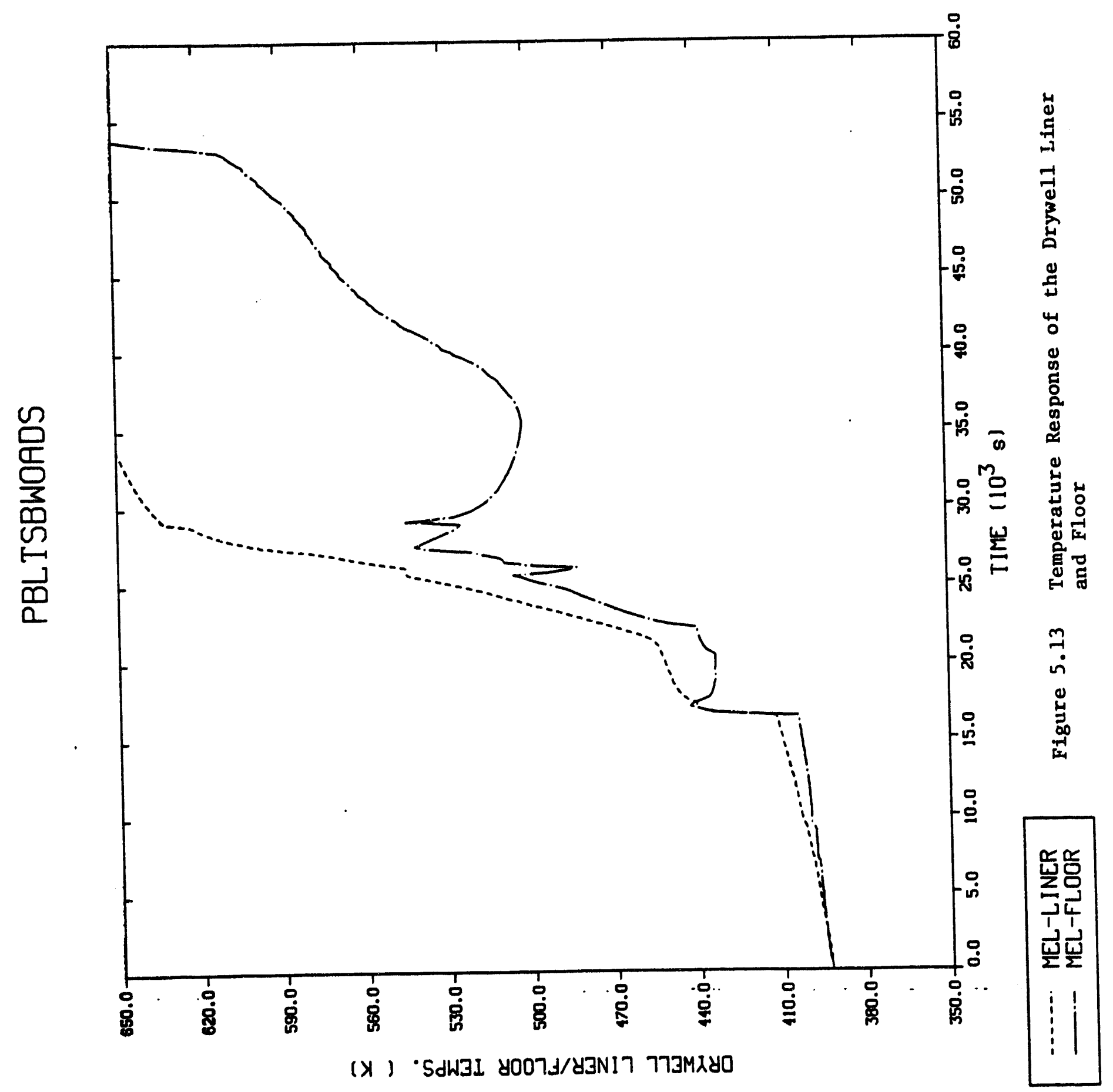


STCP Results/Comparisons

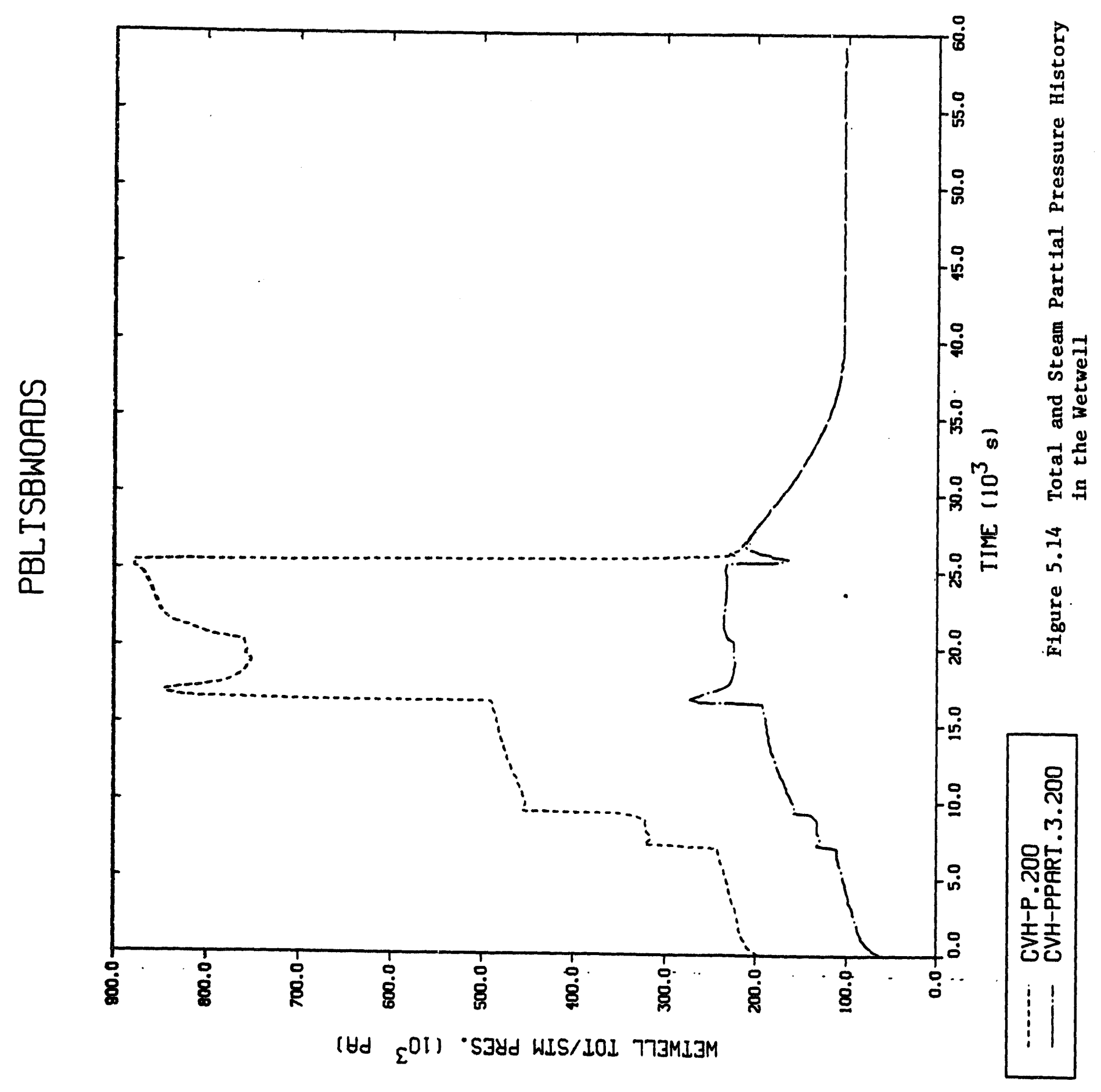




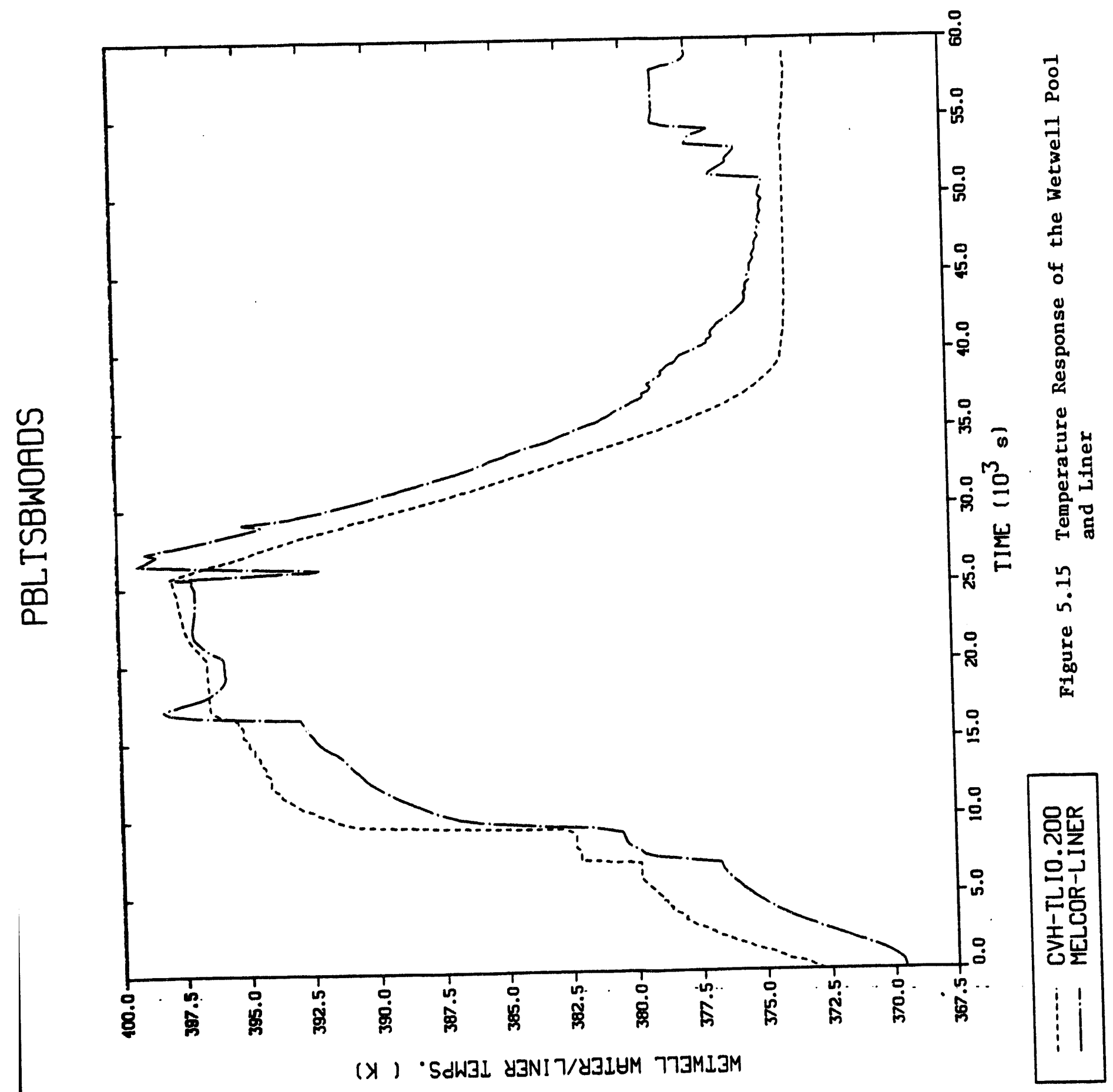




\section{PBLTSBWOADS}

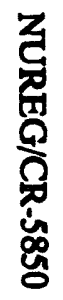

$\tilde{\alpha}$

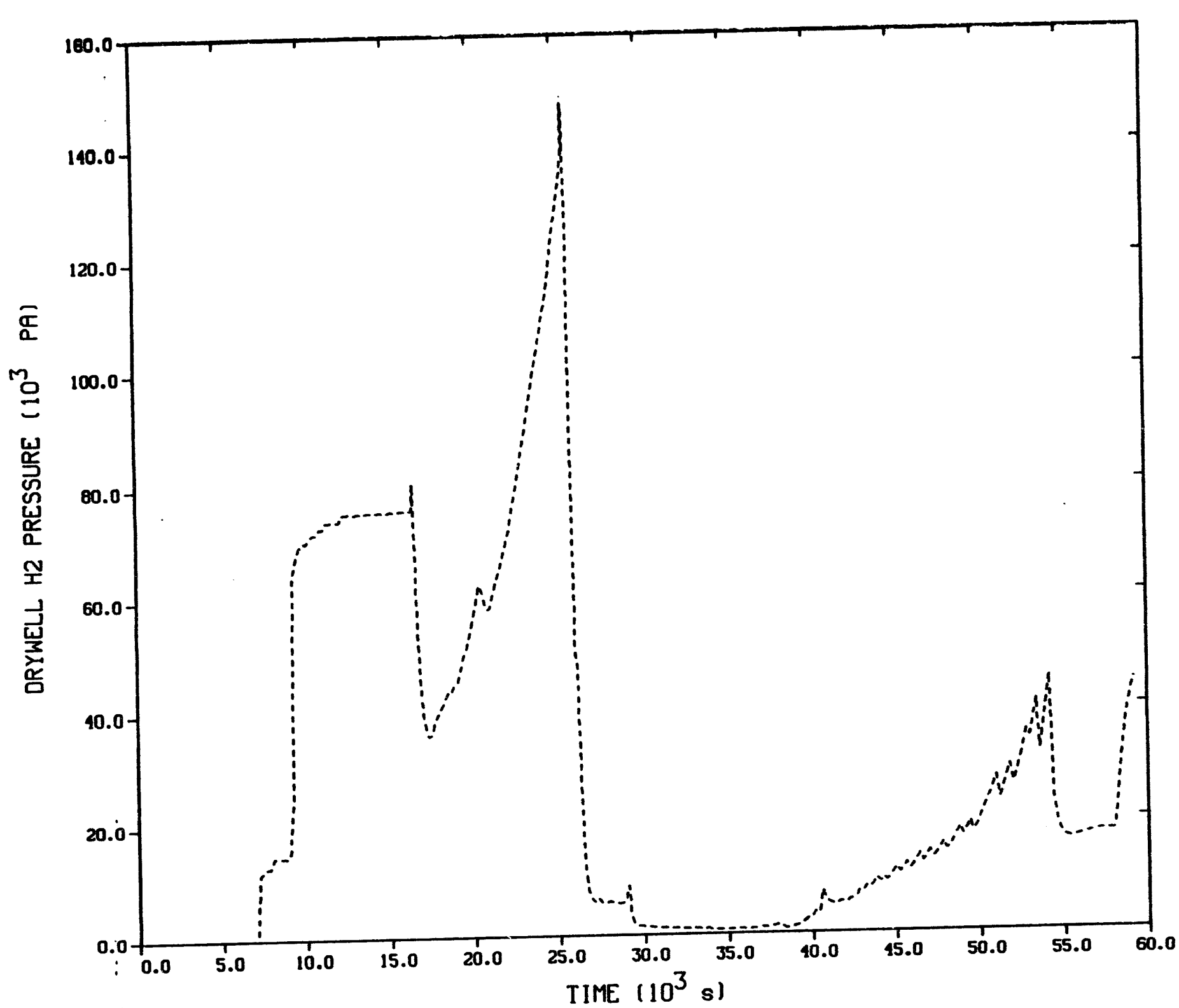




\section{PBLTSBWOADS}

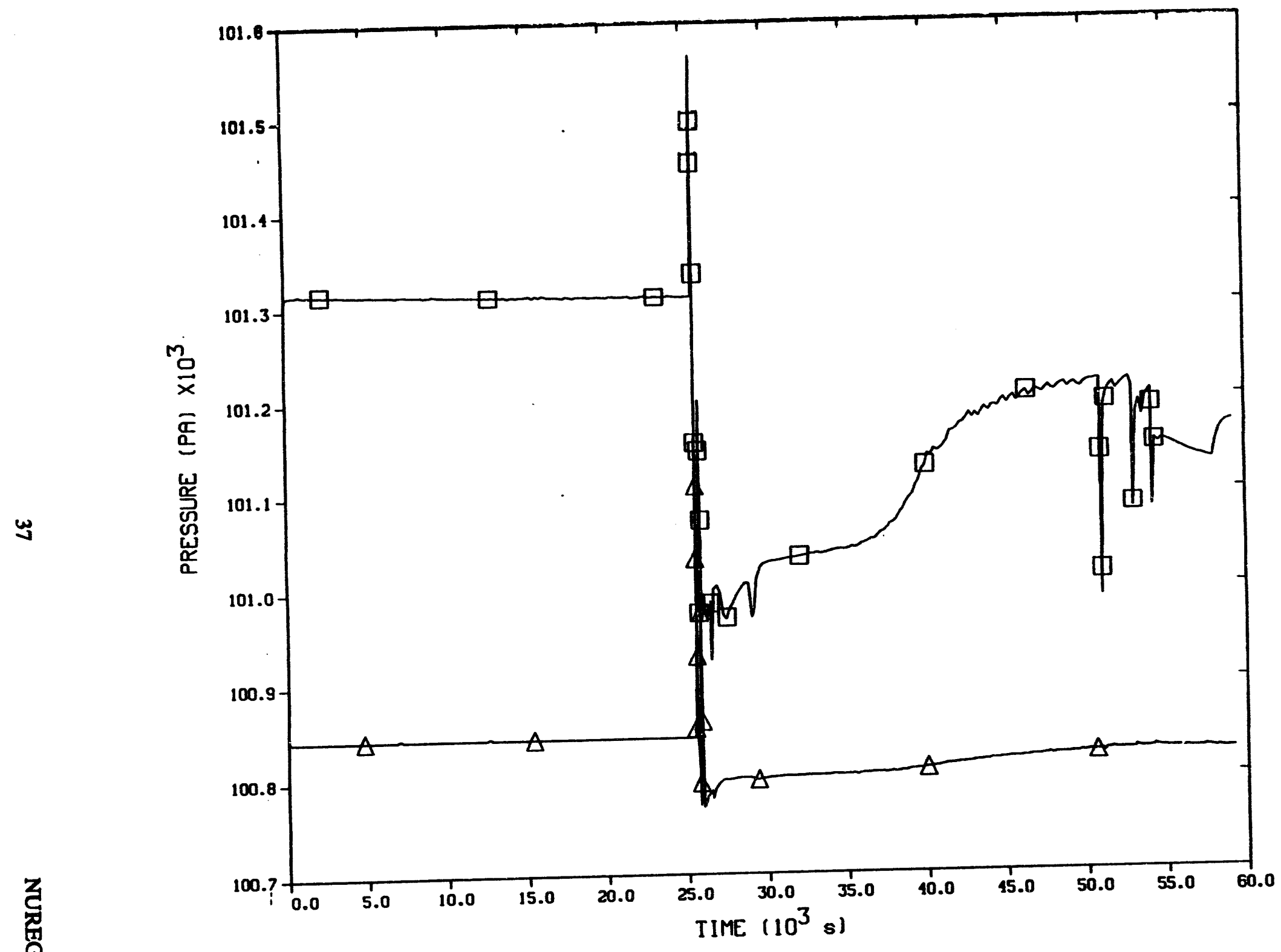




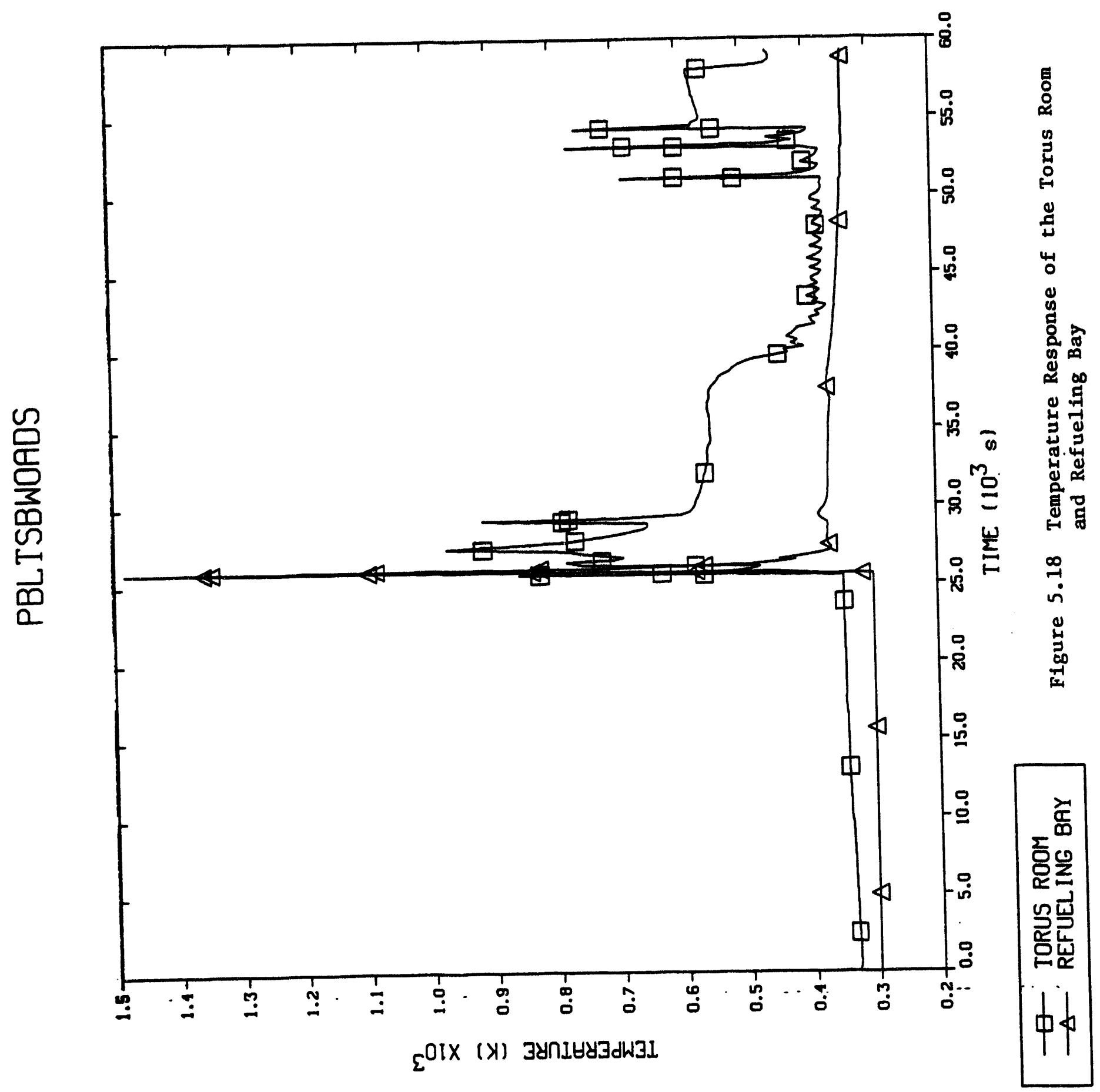




\section{PBLTSBWOADS}

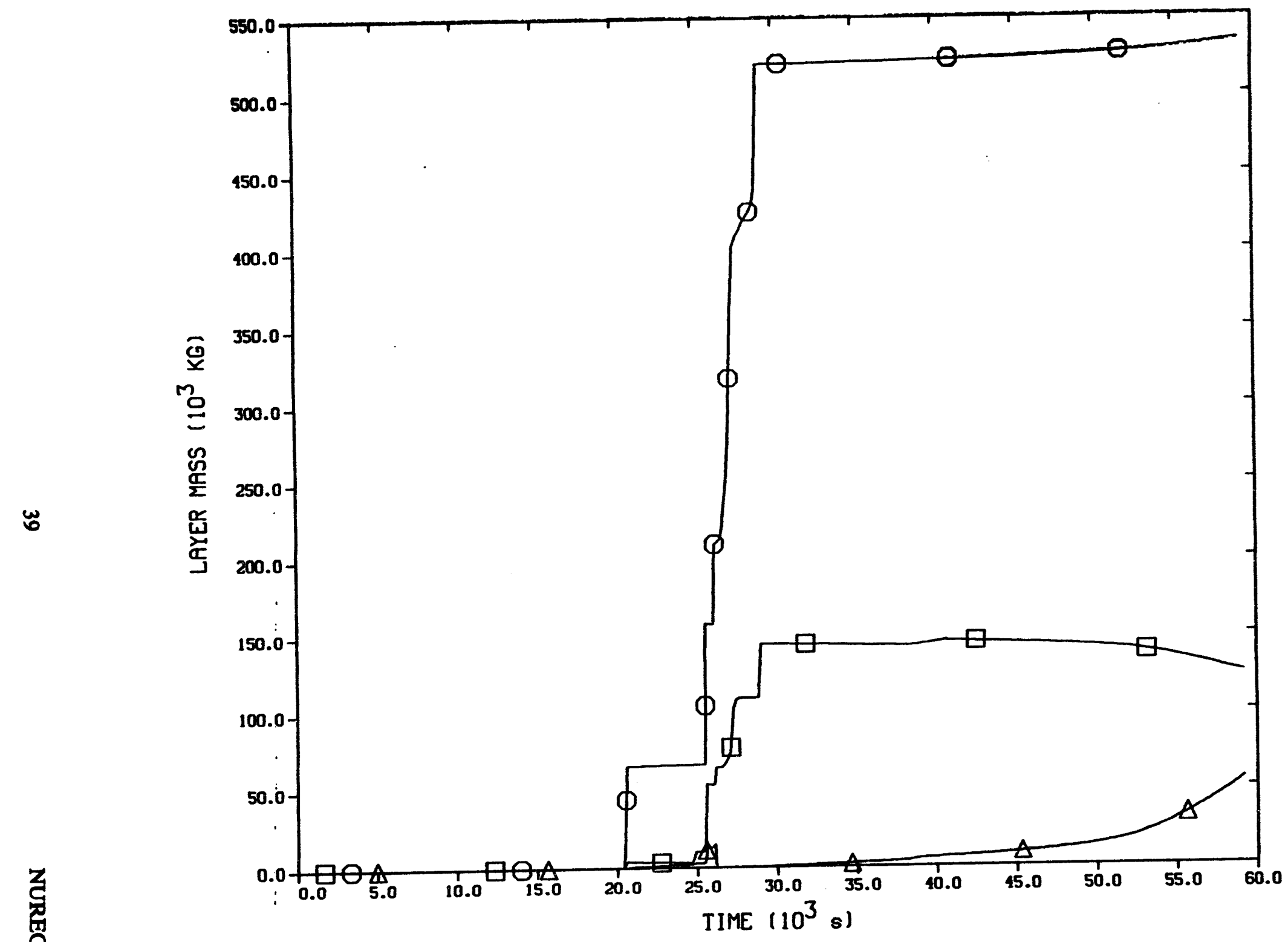

— METAL 


\section{PBLTSBWOADS}

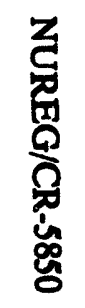

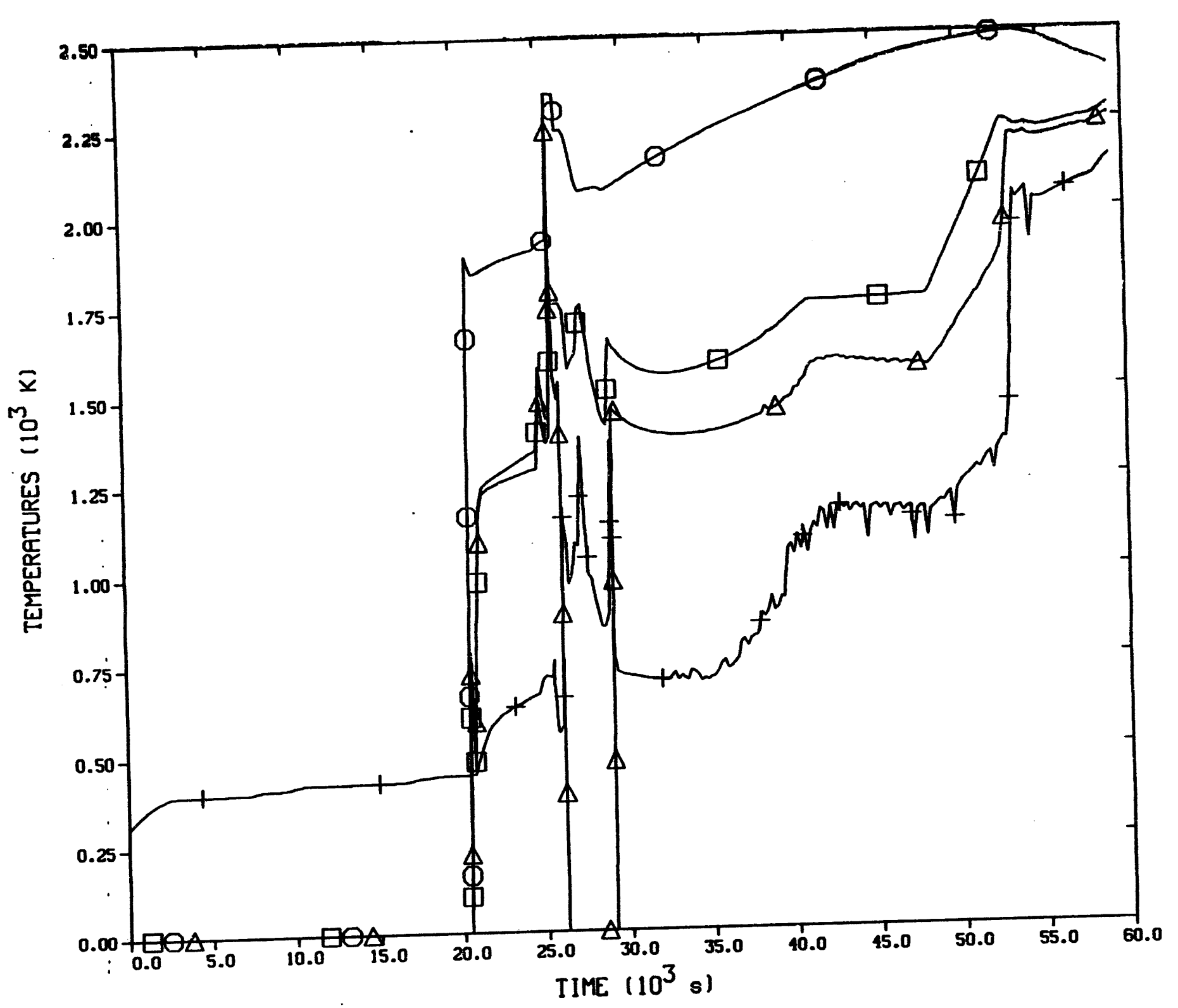


PBLTSBWOADS

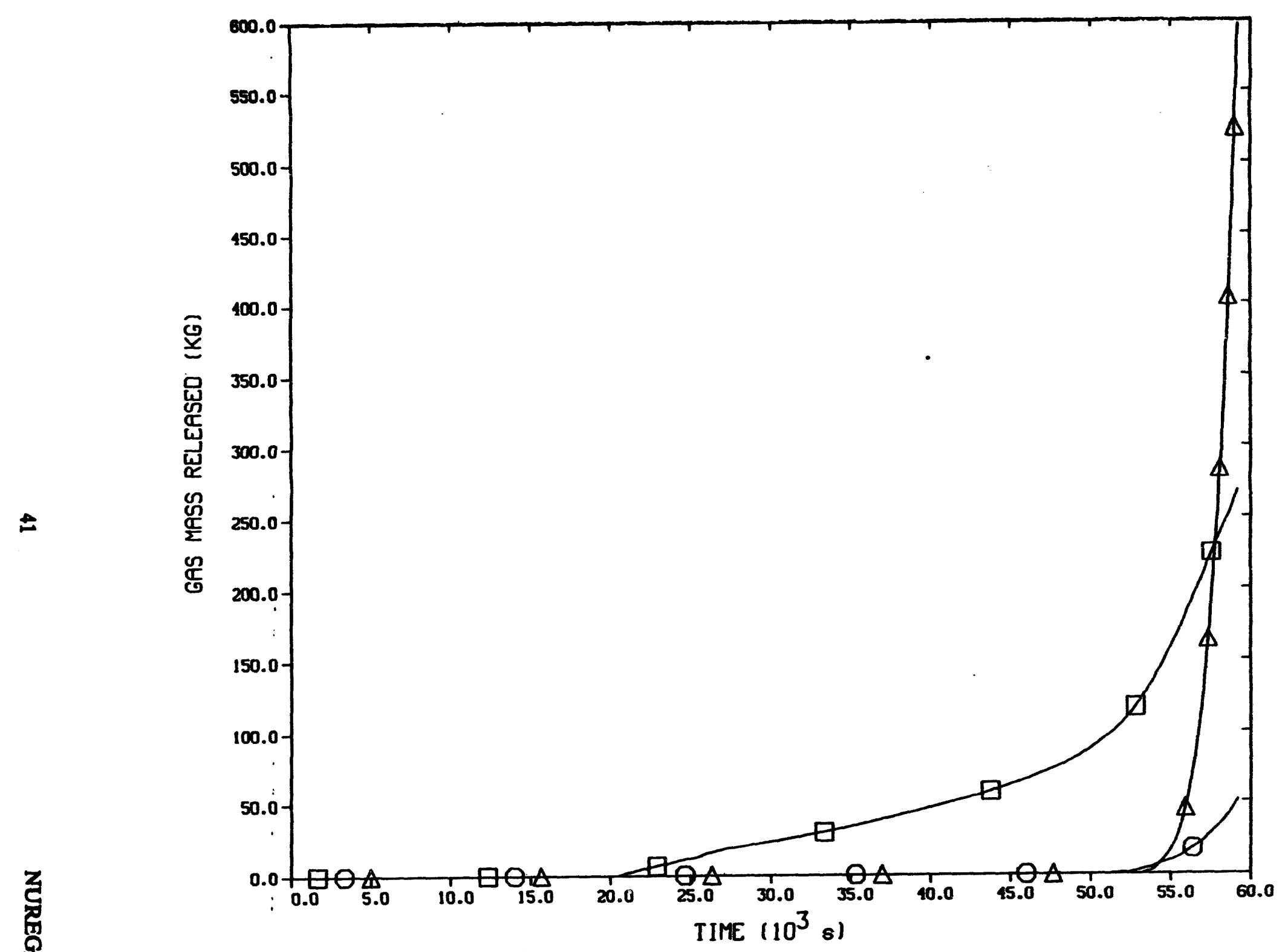

Figure 5.21 Cumulative Mass of Non-Condensible Gases CARBON MONOXIDE CARBON DIOXIDE Released from Core-Concrete Interaction 


\section{RAD MASS RELEASED AND CURRENT STATE}

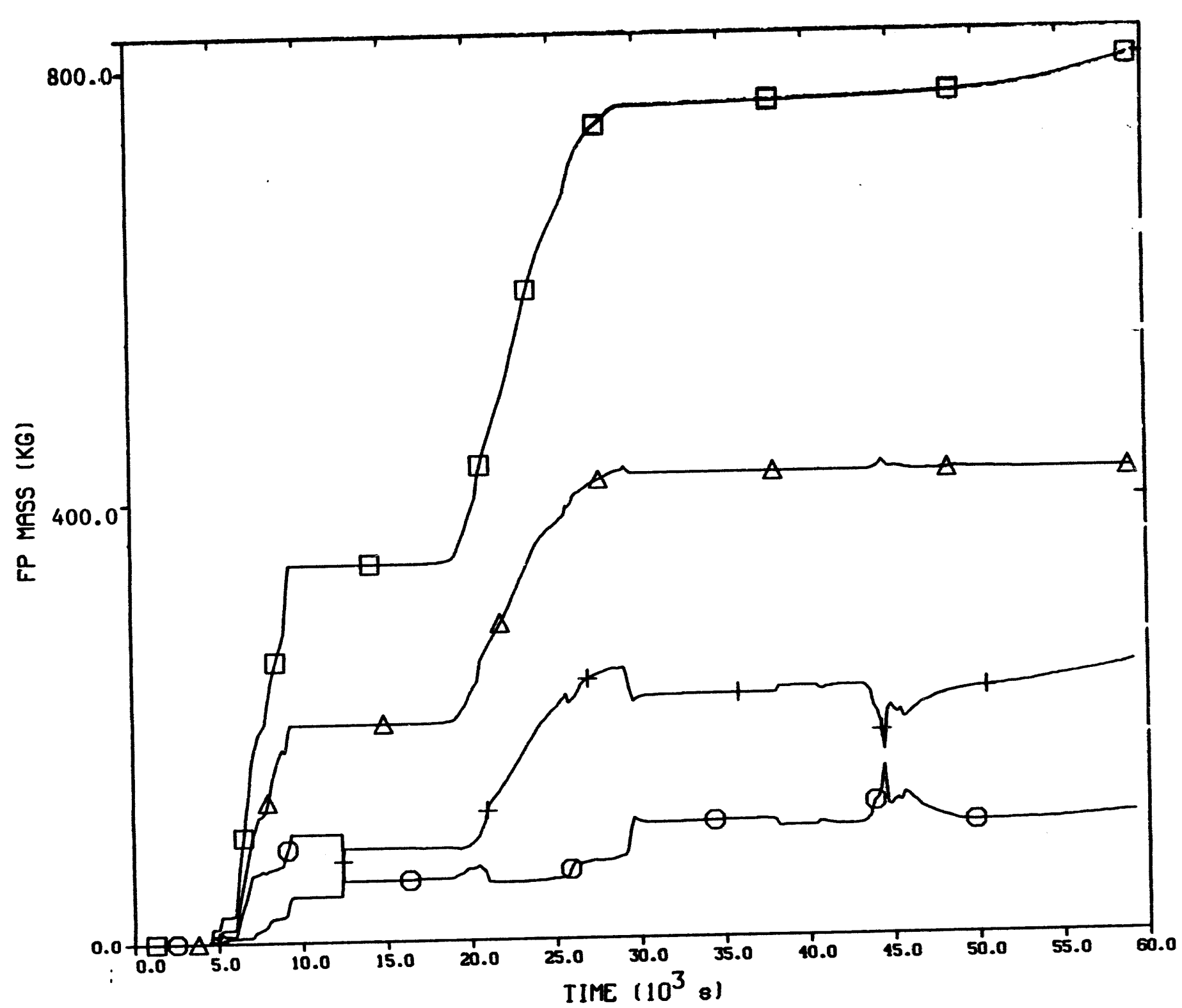

7 TOTAL MASS RELEASED

- - RAD AEROSOL MASS

A RAD FP VAPOR MASS

+ RAD DEPOSITED MASS
Figure 5.22 Cumulative In-Vessel Released and Deposited Mass of Radioactive Fission Products 


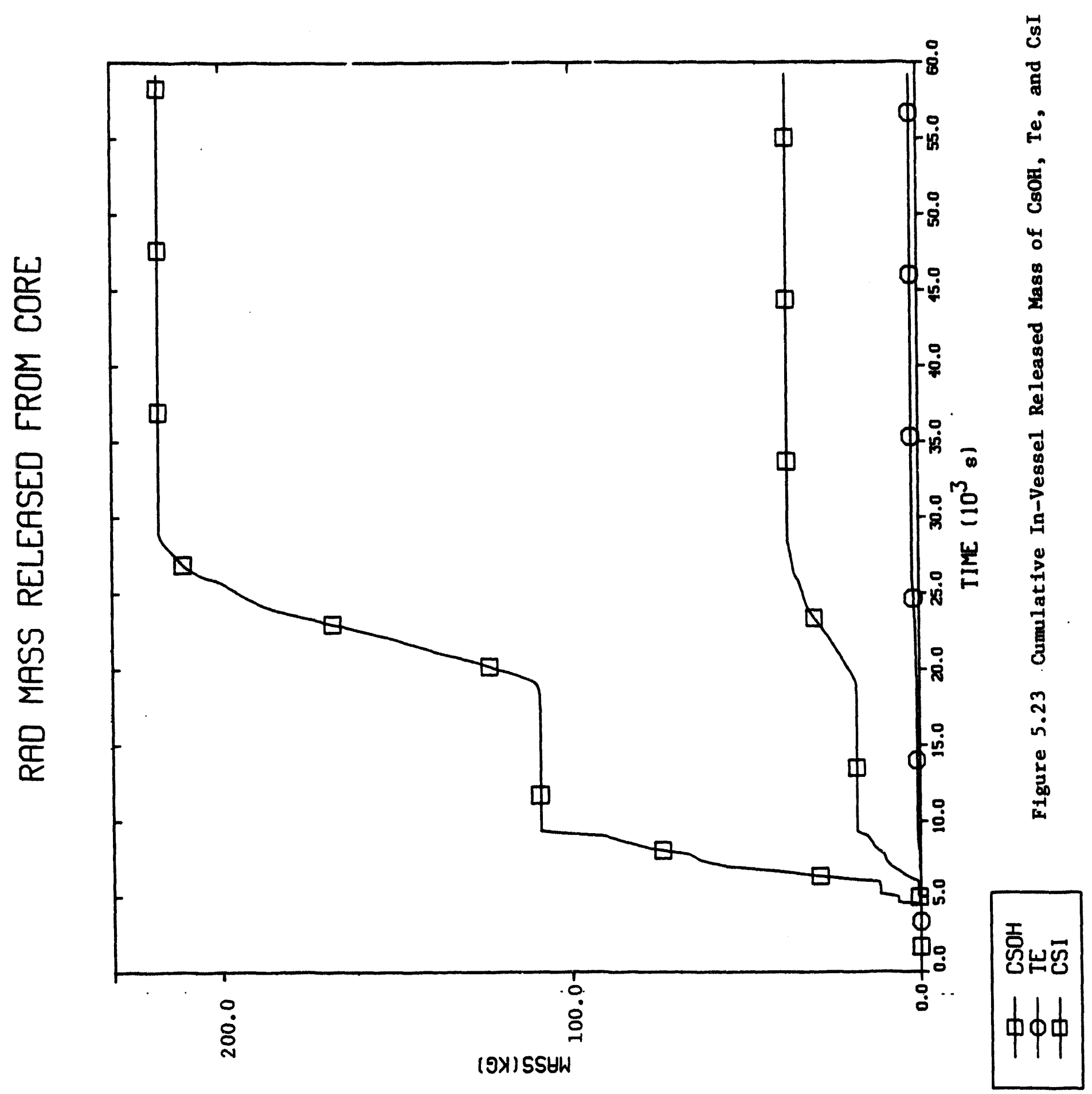




\section{RAD MASS RELEASED FROM CAVITY}

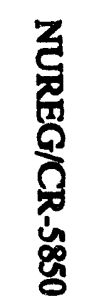

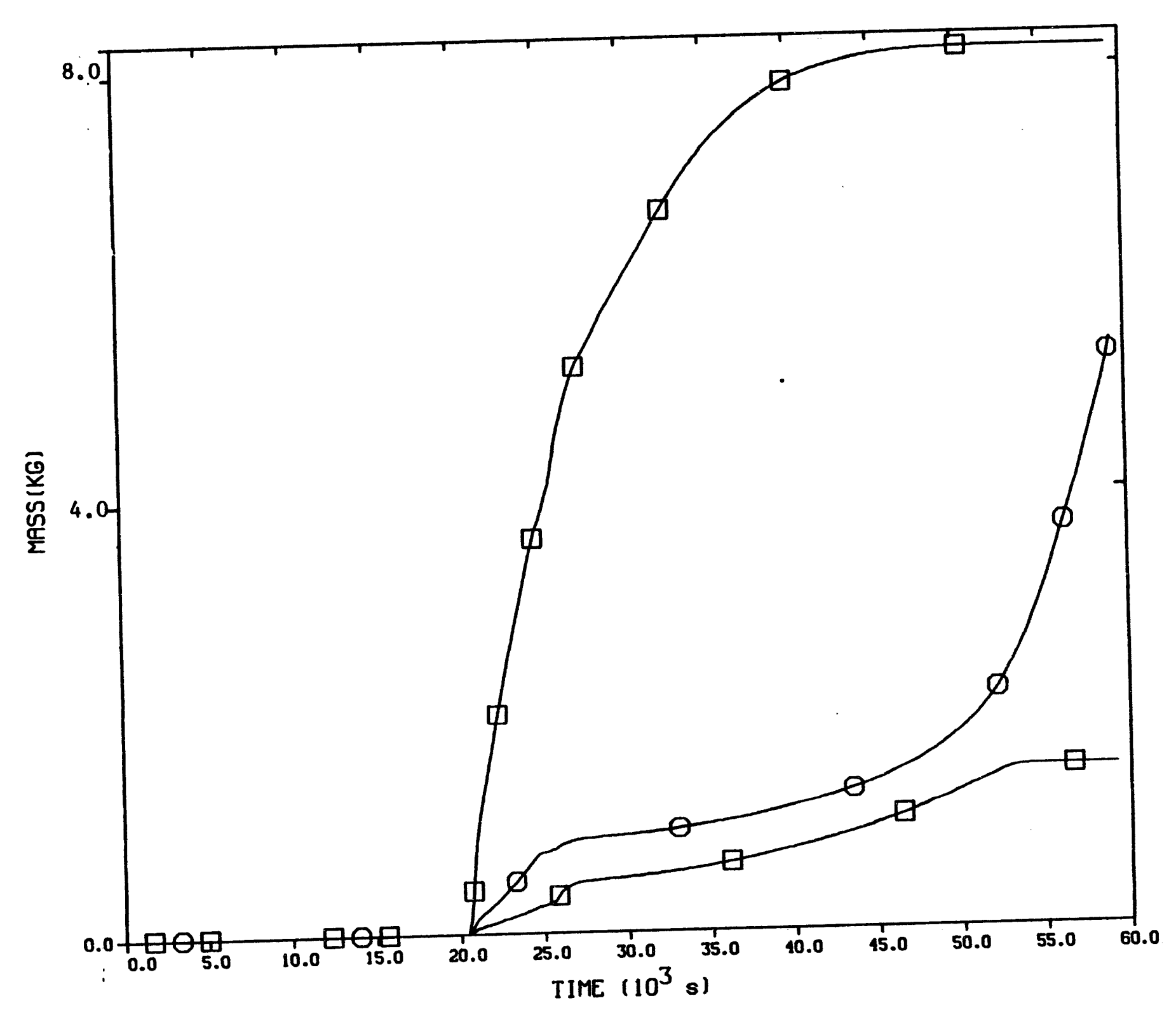

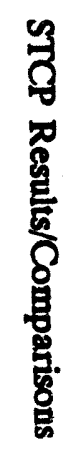

$\$$ 


\section{LOCATION OF DECAY HEAT}

ثै

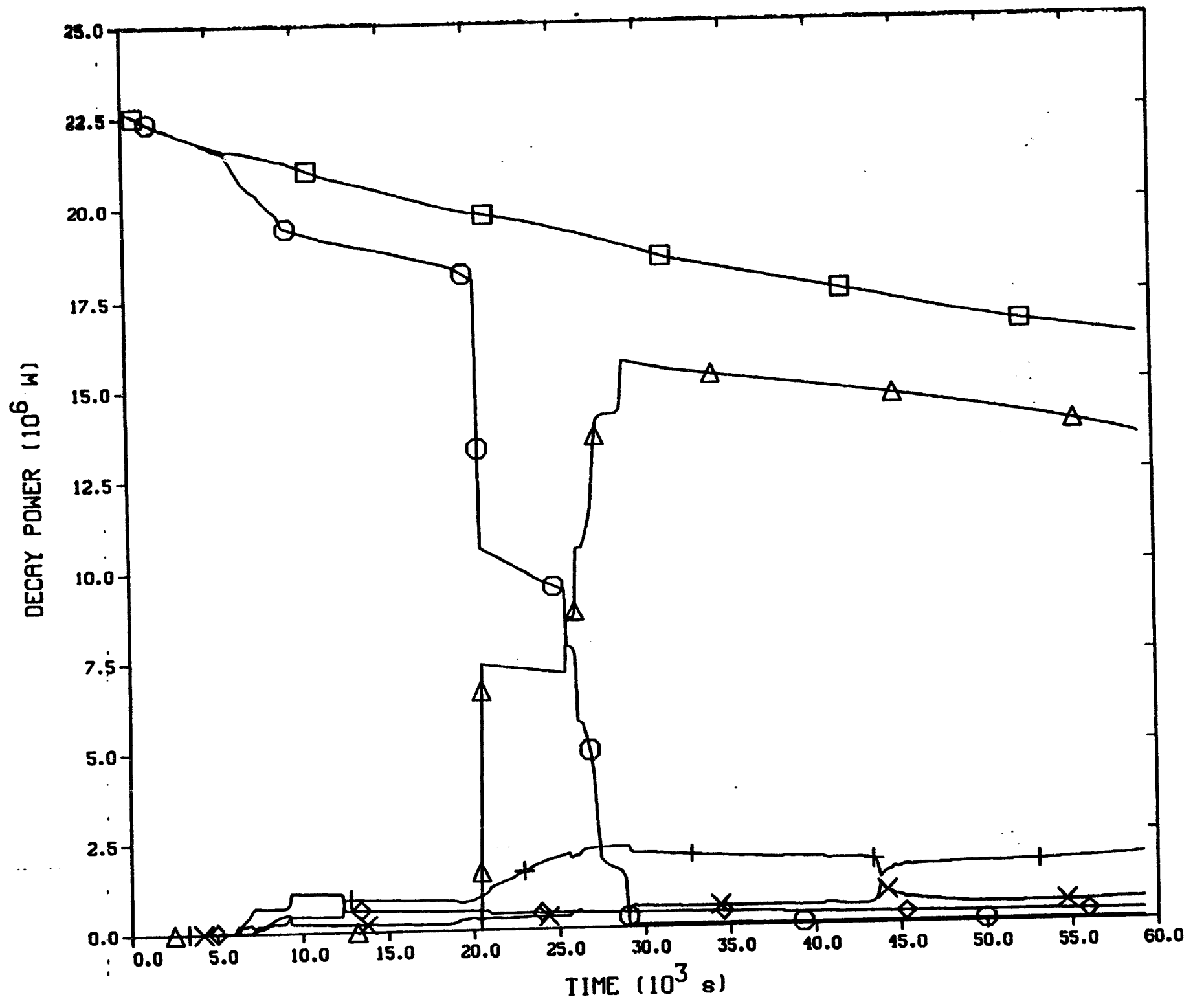

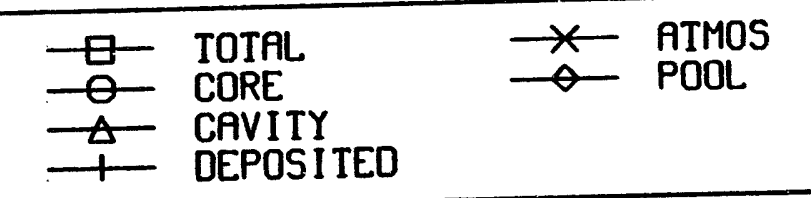

Figure 5.25 Location History of Decay Heat In-Vessel and Ex-Vessel 


\section{Sensitivity Calculations}

In order to explore uncertainties in MELCOR code predictions due to uncertainties in processes, their models, and the convergence properties of the numerical solution, several sensitivity calculations were performed, using the MELCOR model for the Peach Bottom plant but varying user-input modeling and timestep control parameters. Each calculation was a complete sequence simulation, starting with core uncovery and ending 15.0 to 16.7 hours later. The following sections describe variations in fuel release models, refreezing heat transfer coefficients, debris ejection models, burn propagation parameters, and the maximum allowable timestep size for the calculation, and their impact on the predicted timing of key events and environmental releases of radionuclides.

Subsequent to the publication of the draft report, newer updated versions of the code were released. Additional sensitivity calculations and findings from MELCOR 1.8CZ and MELCOR 1.8DNX, are prescrilsed in Appendices $A$ and $B$.

\subsection{Fuel Release Models}

The release of fission products from fuel is modeled in MELCOR using either CORSOR or CORSOR-M. For CORSOR, the release rate is given by [2].

Release rate $($ fraction/min $)=A \exp (B T)$

where $A$ and $B$ are empirical coefficients and $T$ is the core cell component temperature in degrees $C$. $A$ and $B$ are functions of temperature and are radionuclide class specific.

CORSOR-M is an Arrhenius form of the release equation, which is:

Release rate $($ fraction/min $)=k_{0} \exp (-Q / R T)$

where $k_{0} Q$, and $T$ are in units of $\mathrm{min}^{-1}$, kcal/mole, and $K$, respectively. $R$ is $1.987 E-3$. $k_{0}$ and $Q$ are radionuclide class specific.

In addition, these release rates can be modified to be a function of the surface-to-volume ratio of the material, as follows [2]:

Release rate $=$ Release rate $($ CORSOR or CORSOR-M $) \times(S / V)_{\text {arrocuond }} /(S / V)_{\text {beno }}$

where the $(\mathrm{S} / \mathrm{V})_{\text {twe }}$ value is derived from the CORSOR experimental data.

Tables 6.1 and 6.2 present comparisons of predicted timings of key events and environmental releases of radionuclides, respectively, using the models CORSOR with S/V ratio, CORSOR-M with S/V ratio, and CORSOR only. The reference calculation is presented in the first column.

The impact of including $S / V$ ratio on the timing of key events is not seen to be significant. However, the selection of CORSOR-M instead of CORSOR seems to significantly delay the occurrence of all key events starting with core plate failure in Ring 1 . CORSOR alone predicts about 40 percent higher environmental releases of $\mathrm{Cs}$ and CsI, while CORSOR-M with S/N ratio predicts much higher Te (order of magnitude) and CsI (factor of 5) releases compared with the reference calculation.

\subsection{Refreezing Heat Transfer Coefincients}

The core degradation model in MELCOR treats "candling" of molten core materials (i.e., downward flow and subsequent refreezing as they transfer latent heat to cooler structures below). The model is semi-mechanistic based on fundamental thermal-hydraulic principles but incorporating user-specified refreezing heat transfer 
coefficients defined for cach material [2]. Default values built into the code are $1000 \mathrm{~W} / \mathrm{m}^{2}-\mathrm{K}$ for all materials $\left(\mathrm{UO}_{2}\right.$, zircaloy, steel, etc.).

Tables 6.3 and 6.4 present comparisons of predicted timing of key events and environmental releases, respectively, using the reference calculation with the default value of $1000 \mathrm{~W} / \mathrm{m}^{2}-\mathrm{K}$ and a variation using $4000 \mathrm{~W} / \mathrm{m}^{2}-\mathrm{K}$.

The impact of a higher refreezing heat transfer coefficient on predicted results is seen to be relatively small. Vessel failure occurs about 13 minutes earlier, and containment failure is delayed by about $1 / 2$ hour.

Environmental releases are reduced overall, except for $\mathrm{Cs}_{s}$ and $\mathrm{Te}$, which show small increases.

\subsection{Debris Ejection Model}

After a penetration has failed, the mass of material in the bottom axial level that is available for ejection is calculated. Two options exist. In the default option, the masses of each material available for ejection are the total debris material masses, regardless of whether or how much they are melted. This is the solid debris ejection model. In the other option (solid debris ejection model turned off), only molten masses of materials are available for ejection [2].

Tables 6.5 and 6.6 present comparisons of predicted timings of key events and environmental releases, respectively, between the reference calculation using the default option and the variation using the other option. The impact of turning off the solid debris ejection model on the timing of events is observed late in the sequence, only after penetration failure in the second ring. The impact on environmental releases is to increase almost all releases substantially (Cs and Te 80 percent higher, Csi 5.7 times higher).

Tables 6.7 and 6.8 show the impact of using two variations simultaneously (i.e., CORSOR-M with SN ratio, together with solid debris ejection model disabled). The impact on timing is seen to be predominantly due to the fuel release model, whereas the releases to environment are affected by both variations. The combined effect causes a sharp increase in predicted $\mathrm{Ba}$ release and a $\mathbf{5 0}$ percent reduction in CsI release compared with using either variation alone.

\subsection{Burn Propagation Parameter}

During combustion in a control volume, propagation to other control volumes connected to the burning volume is possible and is considered following a delay given by total burn time in the burning volume multiplied by a time fraction, TFRAC, which is user input. If TFRAC $=0.0$, propagation is evaluated as soon as a control volume starts burning. If TFRAC $=1.0$, propagation is only considered at the end of the volume burn. The reference calculation uses TFRAC $=0.25$, and a variation considered is TFRAC $=0.5$.

Tables 6.9 and 6.10 show the impact of this parameter on predicted results. The impact on both timing of key events (Table 6.9) and environmental releases (Table 6.10) is seen to be very small.

\subsection{Maximum Allowable Timestep}

The maximum and minimum allowable timestep sizes are specified on MELCOR input. MELCOR calculates its system timestep based on directives from the various packages, but it cannot take timesteps greater than the maximum timestep or smaller than the minimum timestep. The maximum allowable timestep is user specified and has a definite impact on the calculational behavior of the code. This section explores the effect of this parameter by selecting two variations (i.e., $\Delta t_{\max }=5.0$ seconds and 3.0 seconds) and compares the fredicted results with the reference calculation, which uses $\Delta \mathrm{t}_{\max }=10.0$ seconds.

Both variations are seen to delay to occurrence of most key events compared to the reference calculation (Table 6.11), and to substantially increase the release of source terms to the environment (Table 6.12). This wide disparity in predicted results could be partially attributed to the way MELCOR calculates several key events based on threshold values of temperature or pressure. If the temperature just crosses the threshold for an event in one 


\section{Sensitivity Calculations}

calculation and falls short by $1 \mathrm{~K}$ in another, that could alter the subsequent sequence of events. This uncertainty in results based on a calculational parameter indicates the need for adequate guidelines on selection of the maximum allowable timestep size for convergence of the solution. 
Tabie 6.1 Impact of Fuel Release Model on Predicted Timing of Key Events

\begin{tabular}{|c|c|c|c|}
\hline \multirow{2}{*}{ Key Event } & \multicolumn{3}{|c|}{ Time (min) } \\
\hline & $\begin{array}{l}\text { CORSOR with } \\
\text { S/V Ratio }\end{array}$ & $\begin{array}{l}\text { CORSOR-M with } \\
\text { S/V Ratio }\end{array}$ & $\begin{array}{c}\text { CORsOR } \\
\text { Only }\end{array}$ \\
\hline Core uncovery & 0.0 & 0.0 & 0.0 \\
\hline Fission product release from gap in Ring No. 1 & 76.8 & 76.8 & 76.8 \\
\hline Fission product release from gap in Ring No. 2 & 85.4 & 85.4 & 85.4 \\
\hline Fission product release from gap in Ring No. 3 & 116.4 & 116.5 & 116.6 \\
\hline Core plate failure in Ring No. 1 & 154.4 & 170.8 & 151.7 \\
\hline Lower plenum dryout & 206.3 & 300.9 & 213.8 \\
\hline Vessel failure (penetration Ring No. 1) & 274.0 & 381.1 & 275.4 \\
\hline Reactor vessel depressurized & 275.1 & 382.1 & 276.4 \\
\hline Core plate failure in Ring No. 2 & 327.9 & 412.3 & 329.4 \\
\hline Beginning of debris ejection to cav. & 341.2 & 451.8 & 343.7 \\
\hline Core plate failure in Ring No. 3 & 400.4 & 438.6 & 397.9 \\
\hline Drywell failure & 426.0 & 483.6 & 425.8 \\
\hline Deflagrations start in sec. containment & 426.4 & 484.1 & 426.2 \\
\hline Deflagrations end in sec. containment & 430.8 & 489.2 & 431.0 \\
\hline Lower head penetration fails in Ring No. 2 & 434.9 & 508.0 & 434.9 \\
\hline Deflagrations start in Reactor Bldg. & 441.6 & -- & 442.3 \\
\hline Deflagrations end in Reactor Bldg. & 442.4 & - & 442.4 \\
\hline Lower head penetration fails in Ring No. 3 & 441.4 & 527.5 & 443.3 \\
\hline Fission product release ends & 484.9 & 827.1 & 474. \\
\hline
\end{tabular}


Sensitivity Calculations

Table 6.2 Impact of Fuel Release Model on Predicted Environmental Releases of Radionuclides

\begin{tabular}{|c|c|c|c|c|}
\hline \multirow{2}{*}{ Class Name } & \multirow{2}{*}{ Representative } & \multicolumn{2}{|c|}{$\begin{array}{c}\text { Euvironmental Release } \\
\text { (Fraction) } \\
\end{array}$} & \multirow[b]{2}{*}{$\begin{array}{c}\text { CORSOR } \\
\text { Only }\end{array}$} \\
\hline & & $\begin{array}{l}\text { CORSOR with } \\
\text { S/N Ratio }\end{array}$ & $\begin{array}{l}\text { CORSOR-M } \\
\text { with S/V Ratio }\end{array}$ & \\
\hline Noble Gases & $\mathrm{Xe}$ & 0.998 & 0.999 & 0.997 \\
\hline Alkali Metals & Cs & 0.171 & 0.225 & 0.241 \\
\hline Alkaline Earths & $\mathrm{Ba}$ & 4.13E-02 & $3.96 \mathrm{E}-02$ & $3.86 \mathrm{E}-02$ \\
\hline Halogens & $\mathbf{I}$ & $6.79 \mathrm{E}-03$ & $3.68 \mathrm{E}-08$ & $3.66 \mathrm{E}-04$ \\
\hline Chalcogens & $\mathrm{Te}$ & $1.78 \mathrm{E}-02$ & 0.189 & $2.24 \mathrm{E}-02$ \\
\hline Platinoids & $\mathbf{R u}$ & 8.85E-04 & 1.15E-08 & $7.88 \mathrm{E}-04$ \\
\hline Transition Elements & Mo & $1.80 \mathrm{E}-02$ & $6.68 \mathrm{E}-04$ & $1.56 \mathrm{E}-02$ \\
\hline Tetravalents & $\mathrm{Ce}$ & $1.88 \mathrm{E}-05$ & $2.48 \mathrm{E}-07$ & $1.69 \mathrm{E}-05$ \\
\hline Trivalents & $\mathbf{L a}$ & 8.23E-04 & $1.34 \mathrm{E}-03$ & 8.65E-04 \\
\hline Uranium & $\underline{U}$ & $2.97 \mathrm{E}-05$ & 7.35E-06 & 2.71E-04 \\
\hline More Volatile Metals & Cd & $7.30 \mathrm{E}-02$ & $1.06 \mathrm{E}-04$ & $6.36 \mathrm{E}-02$ \\
\hline Less Volatile Metals & Sn & $7.38 \mathrm{E}-02$ & $1.27 \mathrm{E}-02$ & $6.44 \mathrm{E}-02$ \\
\hline Boron & B & 0.0 & 0.0 & 0.0 \\
\hline Water & $\mathrm{H}_{2} \mathrm{O}$ & 0.0 & 0.0 & 0.0 \\
\hline Concrete & - & 0.0 & 0.0 & 0.0 \\
\hline Cesium Iodide & CsI & $8.56 \mathrm{E}-02$ & 0.5 & 0.118 \\
\hline
\end{tabular}


Table 6.3 Impact of Refireezing Heat Transfer Coeficient on Predicted Timing of Key Events

\begin{tabular}{|c|c|c|}
\hline \multirow{2}{*}{ Key Event } & \multicolumn{2}{|c|}{ Time (min) } \\
\hline & $\begin{array}{c}\text { Refreezing Heat } \\
\text { Transfer } \\
\text { Coefi }=1000 \mathrm{~W} / \mathrm{m}^{2}-\mathrm{K} \\
\text { (DeI) }\end{array}$ & $\begin{array}{l}\text { Refireezing Heat } \\
\text { Transfer } \\
\text { Coefi }=4000 \mathrm{~W} / \mathrm{m}^{2} \text { - } \\
\mathbf{K}\end{array}$ \\
\hline Core uncovery & 0.0 & 0.0 \\
\hline Fission product release from gap in Ring No. 1 & 76.8 & 76.8 \\
\hline Fission product release from gap in Ring No. 2 & 85.4 & 85.4 \\
\hline Fission product release from gap in Ring No. 3 & 116.4 & 116.4 \\
\hline Core plate failure in Ring No. 1 & 154.4 & 137.1 \\
\hline Lower plenum dryout & 206.3 & 209.2 \\
\hline Vessel failure (penetration Ring No. 1) & 274.0 & 260.6 \\
\hline Reactor vessel depressurized & 275.1 & 261.7 \\
\hline Core plate failure in Ring No. 2 & 327.9 & 316.6 \\
\hline Beginning of debris ejection to cav. & 341.2 & 328.1 \\
\hline Core plate failure in Ring No. 3 & 400.4 & 397.4 \\
\hline Drywell failure & 426.0 & 460.4 \\
\hline Deflagrations start in secondary containment & 426.4 & $\cdots$ \\
\hline Deflagrations end in secondary containment & 430.8 & $\cdots$ \\
\hline Lower head penetration fails in Ring No. 2 & 434.9 & 459.5 \\
\hline Deflagrations start in Reactor Bldg. & 441.6 & 460.7 \\
\hline Deflagrations end in Reactor Bldg. & 442.4 & 464.7 \\
\hline Lower head penetration fails in Ring No. 3 & 441.4 & 465.5 \\
\hline Fission product release ends & 484.9 & 476.2 \\
\hline
\end{tabular}


Sensitivity Calculations

Table 6.4 Impact of Refreexing Heat Transfer on Predicted Environmental Releases of Radionuclides

\begin{tabular}{|c|c|c|c|}
\hline \multirow{2}{*}{ Class Name } & \multirow{2}{*}{ Representative } & \multicolumn{2}{|c|}{$\begin{array}{l}\text { Environmental Release } \\
\text { (Fraction) }\end{array}$} \\
\hline & & $h_{n}=1000 \mathrm{~W} / \mathrm{m}^{2}-k$ & $h_{n}=4000 \mathrm{~W} / \mathrm{m}^{2} \cdot \mathrm{k}$ \\
\hline Noble Grses & $\mathbf{X e}$ & 0.998 & 0.997 \\
\hline Alkali Metals & Cs & 0.171 & 0.195 \\
\hline Alkaline Earths & $\mathbf{B a}$ & 4.13E-02 & 2.14E-02 \\
\hline Halogens & I & $6.79 \mathrm{E}-03$ & $7.41 \mathrm{E}-03$ \\
\hline Chalcogens & $\mathrm{Te}$ & $1.78 \mathrm{E}-02$ & 2.19E-02 \\
\hline Platinoids & $\mathbf{R u}$ & 8.85E-04 & $4.19 \mathrm{E}-04$ \\
\hline Transition Elements & Mo & $1.80 \mathrm{E}-02$ & 8.37E-03 \\
\hline Tetravalents & $\mathrm{Ce}$ & $1.88 \mathrm{E}-05$ & $9.78 \mathrm{E}-06$ \\
\hline Trivalents & La & 8.23E-04 & 2.25E-04 \\
\hline Uranium & $\mathbf{U}$ & 2.97E-05 & $1.46 \mathrm{E}-05$ \\
\hline More Volatile Metals & Cd & $7.30 \mathrm{E}-02$ & 2.82E-02 \\
\hline Less Volatile Metals & Sn & $7.38 \mathrm{E}-02$ & $2.87 \mathrm{E}-02$ \\
\hline Boron & $\mathbf{B}$ & 0.0 & 0.0 \\
\hline Water & $\mathrm{H}_{2} \mathrm{O}$ & 0.0 & 0.0 \\
\hline Concrete & - & 0.0 & 0.0 \\
\hline Cesium Iodide & CsI & $8.56 \mathrm{E}-02$ & $5.21 \mathrm{E}-02$ \\
\hline
\end{tabular}


Table 6.5 Impact of Debris Ejection Model on Predicted Timing of Key Events

\begin{tabular}{|c|c|c|}
\hline \multirow[b]{2}{*}{ Key Event } & \multicolumn{2}{|c|}{ Time (min) } \\
\hline & $\begin{array}{c}\text { Solid Debris Ejection } \\
\text { Model Active } \\
\text { (Definult) }\end{array}$ & $\begin{array}{c}\text { Solid Debris } \\
\text { Ejection Model } \\
\text { Disabled }\end{array}$ \\
\hline Core uncovery & 0.0 & 0.0 \\
\hline Fission product release from gap in Ring No. 1 & 76.8 & 76.8 \\
\hline Fission product release from gap in Ring No. 2 & 85.4 & 85.4 \\
\hline Fission product release from gap in Ring No. 3 & 116.4 & 116.4 \\
\hline Core plate failure in Ring No. 1 & 154.4 & 154.4 \\
\hline Lower plenum dryout & 206.3 & 206.3 \\
\hline Vessel failure (penetration Ring No. 1) & 274.0 & 274.0 \\
\hline Reactor vessel depressurized & 275.1 & 275.1 \\
\hline Core plate failure in Ring No. 2 & $\mathbf{3 2 7 . 9}$ & 327.9 \\
\hline Beginning of debris ejection to cav. & 341.2 & 341.2 \\
\hline Core plate failure in Ring No. 3 & 400.4 & 400.4 \\
\hline Drywell failure & 426.0 & 426.0 \\
\hline Deflagrations start in secondary containment & 426.4 & 426.4 \\
\hline Deflagrations end in secondary containment & 430.8 & 430.8 \\
\hline Lower head penetration fails in Ring No. 2 & 434.9 & 434.9 \\
\hline Deflagrations start in Reactor Bldg. & 441.6 & $\cdots$ \\
\hline Deflagrations end in Reactor Bldg. & 442.4 & $\cdots$ \\
\hline Lower head penetration fails in Ring No. 3 & 441.4 & 447.7 \\
\hline Fission product release ends & 484.9 & 480.7 \\
\hline
\end{tabular}


Sensitivity Calculations

Table 6.6 Impact of Debris Ejection Model on Predicted Environmental Releases of Radionuclides

\begin{tabular}{|c|c|c|c|}
\hline \multirow{2}{*}{ Class Name } & \multirow{2}{*}{ Representative } & \multicolumn{2}{|c|}{$\begin{array}{c}\text { Environmental Release } \\
\text { (Fraction) } \\
\end{array}$} \\
\hline & & $\begin{array}{c}\text { Solld Debris } \\
\text { Ejection Model } \\
\text { Active }\end{array}$ & $\begin{array}{l}\text { Solid Debris } \\
\text { Ejection Model } \\
\text { Disabled }\end{array}$ \\
\hline Noble Gases & $\mathbf{X e}$ & 0.998 & 0.998 \\
\hline Alkali Metals & Cs & 0.171 & 0.309 \\
\hline Alkaline Earths & $\mathrm{Ba}$ & 4.13E-02 & 4.81E-02 \\
\hline Halogens & I & $6.79 \mathrm{E}-03$ & 0.0 \\
\hline Chalcogens & Te & $1.78 \mathrm{E}-02$ & $3.19 \mathrm{E}-02$ \\
\hline Platinoids & $\mathbf{R u}$ & 8.85E-04 & $1.05 \mathrm{E}-03$ \\
\hline Transition Elements & Mo & $1.80 \mathrm{E}-02$ & $2.13 \mathrm{E}-02$ \\
\hline Tetravalonts & $\mathrm{Ce}$ & $1.88 \mathrm{E}-05$ & $2.02 \mathrm{E}-05$ \\
\hline Trivalents & $\mathbf{L a}$ & $8.23 \mathrm{E}-04$ & $1.34 \mathrm{E}-03$ \\
\hline Uranium & $\mathbf{U}$ & $2.97 \mathrm{E}-05$ & $3.29 \mathrm{E}-05$ \\
\hline More Volatile Metals & Cd & $7.30 \mathrm{E}-02$ & $8.41 \mathrm{E}-02$ \\
\hline Less Volatile Metals & Sn & $7.38 \mathrm{E}-02$ & $8.50 \mathrm{E}-02$ \\
\hline Boron & B & 0.0 & 0.0 \\
\hline Water & $\mathrm{H}_{2} \mathrm{O}$ & 0.0 & 0.0 \\
\hline Concrete & - & 0.0 & 0.0 \\
\hline Cesium Iodide & CsI & $8.56 \mathrm{E}-02$ & 0.488 \\
\hline
\end{tabular}


Table 6.7 Impact of Combination of Fuel Release Model and Dobris Ejection Model Solection on Predicted Timing of Koy Events

\begin{tabular}{|c|c|c|}
\hline \multirow{2}{*}{ Key Event } & \multicolumn{2}{|c|}{ Time (min) } \\
\hline & $\begin{array}{l}\text { Base Case (CORSOR } \\
\text { SN Ratio a Solld } \\
\text { Dobris Dection On) }\end{array}$ & $\begin{array}{c}\text { CORSOR-M SN } \\
\text { Ratio \& Solid } \\
\text { Dobris Ebection OA }\end{array}$ \\
\hline Core uncovery & 0.0 & 0.0 \\
\hline Fission product release from gap in Ring No. 1 & 76.8 & 76.8 \\
\hline Fission product release from gap in Ring No. 2 & 85.4 & 85.4 \\
\hline Fission product release from gap in Ring No. 3 & 116.4 & 116.5 \\
\hline Core plate failure in Ring No. 1 & 154.4 & 170.8 \\
\hline Lower plenum dryout & 206.3 & 300.9 \\
\hline Vessel failure (penetration Ring No. 1) & 274.0 & 381.1 \\
\hline Reactor vessel depressurized & 275.1 & 382.1 \\
\hline Core plate failure in Ring No. 2 & 327.9 & 412.3 \\
\hline Beginning of debris ejection to cav. & 341.2 & 451.8 \\
\hline Core plate failure in Ring No. 3 & 400.4 & 438.6 \\
\hline Drywell failure & 426.0 & 483.6 \\
\hline Deflagrations start in secondary containment & 426.4 & 484.1 \\
\hline Deflagrations end in secondary containment & 430.8 & 489.2 \\
\hline Lower head penetration fails in Ring No. 2 & 434.9 & 508.0 \\
\hline Deflagrations start in Reactor Bldg. & 441.6 & 819.0 \\
\hline Deflagrations end in Reactor Bldg. & 442.4 & 884.0 \\
\hline Lower head penetration fails in Ring No. 3 & 441.4 & 519.6 \\
\hline Fission product release ends & 484.9 & 884.7 \\
\hline
\end{tabular}




\begin{tabular}{|c|c|c|c|}
\hline 8270 & $20-3958$ & I85 & op!poI unfses \\
\hline 00 & $0^{\prime} 0$ & - & ข10เుா \\
\hline $0^{\circ} 0$ & 0.0 & $\mathrm{O}^{2} \mathrm{H}$ & JOIBM \\
\hline 0.0 & 00 & $\mathbf{a}$ & nosog \\
\hline $20-9+8 \cdot 1$ & $20-38 E L$ & us & 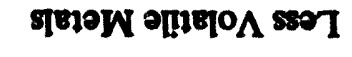 \\
\hline to-goze & 20-GOEL & PO & 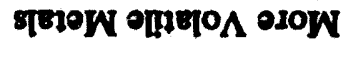 \\
\hline so-a1/9'7 & $50-3 / 6 \% 2$ & $\mathbf{n}$ & mn!uein \\
\hline EO-Z0Z゙L & p0-aEC8 & Eา & 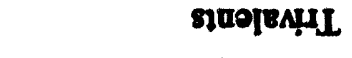 \\
\hline $90-\mathrm{B} 06^{\circ} \mathrm{E}$ & SO-G88'I & $\infty$ & 8ZLOPEAENOI \\
\hline EO-GEL'E & $20-308^{\circ} I$ & ow & nuoworg nongsuredL \\
\hline 80-E182E & t0.9588 & nd & sp!oupud \\
\hline $\operatorname{Lec} 0$ & $20-38 L I$ & Ol & 8408001840 \\
\hline 0.0 & E0-96L'9 & I & su०807еH \\
\hline 8270 & 20-aet't & $\mathbf{8}$ & sपนrg ou!lositV \\
\hline 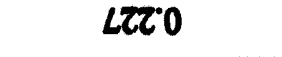 & LLI"O & 85 & 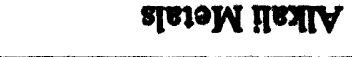 \\
\hline $0^{\circ} \mathrm{I}$ & $866^{\circ} 0$ & $\boldsymbol{\theta X}$ & soseD O \\
\hline 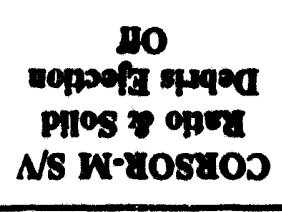 & 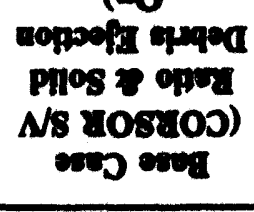 & \multirow[t]{2}{*}{ oupunaserdoy } & \multirow[t]{2}{*}{ 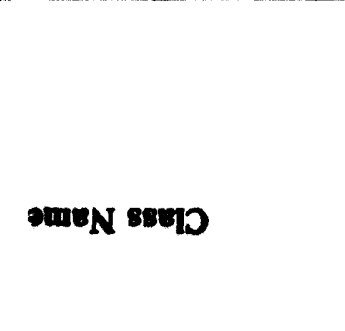 } \\
\hline 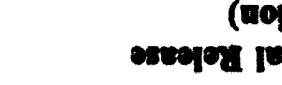 & Dapnex & & \\
\hline
\end{tabular}

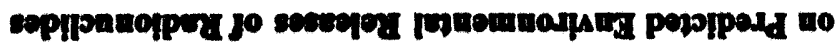

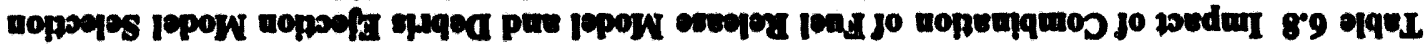


Table 6.9 Impact of Burn Propegation Parnmoter, $T_{\text {mos }}$ on Prodictod Timing of Koy Dvents

\begin{tabular}{|c|c|c|}
\hline \multirow{2}{*}{ Key Event } & \multicolumn{2}{|c|}{$\operatorname{Time}(\min )$} \\
\hline & $T_{\text {tem }}=0.25$ (Dofault) & $T_{\text {tme }}=0.5$ \\
\hline Core uncovery & 0.0 & 0.0 \\
\hline Fission product release from gap in Ring No. 1 & 76.8 & 76.8 \\
\hline Fission product release from gap in Ring No. 2 & 85.4 & 85.4 \\
\hline Fission product release from gap in Ring No. 3 & 116.4 & 116.4 \\
\hline Core plate failure in Ring No. 1 & 154.4 & 154.4 \\
\hline Lower plenum dryout & 206.3 & 206.3 \\
\hline Vessel failure (penetration Ring No. 1) & 274.0 & 274.0 \\
\hline Reactor vessel depressurized & 275.1 & 275.1 \\
\hline Core plate failure in Ring No. 2 & 327.9 & 327.9 \\
\hline Beginning of debris ojection to cav. & 341.2 & 341.2 \\
\hline Core plate failure in Ring No. 3 & 400.4 & 400.4 \\
\hline Drywell failure & 426.0 & 426.0 \\
\hline Deflagrations start in secondary containment & 426.4 & 426.4 \\
\hline Deflagrations end in secondary containment & 430.8 & 430.9 \\
\hline Lower head penetration fails in Ring No. 2 & 434.9 & 434.8 \\
\hline Deflagrations start in Reactor Bldg. & 441.6 & 442.3 \\
\hline Deflagrations end in Reactor Bldg. & 442.4 & 442.4 \\
\hline Lower head penetration fails in Ring No. 3 & 441.4 & 454.5 \\
\hline Fission product release ends & 484.9 & 493.5 \\
\hline
\end{tabular}


Sensitivity Calculations

Table 6.10 Impact of Burm Propagation Parameter, $T_{\text {meso }}$ on Predicted Environmental Releases of Radionuclides

\begin{tabular}{|c|c|c|c|}
\hline \multirow{2}{*}{ Class Name } & \multirow{2}{*}{ Representative } & \multicolumn{2}{|c|}{$\begin{array}{c}\text { Environmental Release } \\
\text { (Traction) } \\
\end{array}$} \\
\hline & & $T_{\max }=0.25$ & $T_{\text {tax }}=0.5$ \\
\hline Noble Gases & $\mathbf{X e}$ & 0.998 & 0.998 \\
\hline Alkali Metals & Cs & 0.171 & 0.144 \\
\hline Alkaline Earths & $\mathbf{B a}$ & 4.13E-02 & 5.07E-02 \\
\hline Halogens & $\mathbf{I}$ & $6.79 \mathrm{E}-03$ & $4.68 \mathrm{E}-02$ \\
\hline Chalcogens & Te & $1.78 \mathrm{E}-02$ & 2.95E-02 \\
\hline Platinoids & $\mathbf{R u}$ & 8.85E-04 & $9.92 \mathrm{E}-04$ \\
\hline Transition Elements & Mo & $1.80 \mathrm{E}-02$ & $1.83 E-02$ \\
\hline Tetravalents & $\mathrm{Ce}$ & $1.88 \mathrm{E}-05$ & 2.15E-05 \\
\hline Trivalents & $\mathbf{L a}$ & $8.23 \mathrm{E}-04$ & $9.66 \mathrm{E}-04$ \\
\hline Uranium & $\mathbf{U}$ & 2.97E-05 & $3.48 \mathrm{E}-05$ \\
\hline More Volatile Metals & Cd & $7.30 \mathrm{E}-02$ & $7.56 \mathrm{E}-02$ \\
\hline Less Volatile Metals & Sn & $7.38 \mathrm{E}-02$ & $7.68 \mathrm{E}-02$ \\
\hline Boron & B & 0.0 & 0.0 \\
\hline Water & $\mathrm{H}_{2} \mathrm{O}$ & 0.0 & 0.0 \\
\hline Concrete & - & 0.0 & 0.0 \\
\hline Cesium Iodide & CsI & $8.56 \mathrm{E}-02$ & 0.10 \\
\hline
\end{tabular}


Table 6.11 Impact of Maximum Allowable Timestep Size on Predicted Timing of Key Events

\begin{tabular}{|c|c|c|c|}
\hline \multirow{2}{*}{ Key Event } & \multicolumn{3}{|c|}{ Time (min) } \\
\hline & $\Delta t_{\max }=10.0 \mathrm{~s}$ & $\Delta t_{\text {mex }}=5.0 \mathrm{~s}$ & $\Delta t_{\max }=3.0 \mathrm{~s}$ \\
\hline Core uncovery & 0.0 & 0.0 & 0.0 \\
\hline $\begin{array}{l}\text { Fission product release from gap in } \\
\text { Ring No. } 1\end{array}$ & 76.8 & 76.6 & 75.7 \\
\hline $\begin{array}{l}\text { Fission product release from gap in } \\
\text { Ring No. } 2\end{array}$ & 85.4 & 85.3 & 84.4 \\
\hline $\begin{array}{l}\text { Fission product release from gap in } \\
\text { Ring No. } 3\end{array}$ & 116.4 & 343.5 & 115.0 \\
\hline Core plate failure in Ring No. 1 & 154.4 & 148.6 & 153.6 \\
\hline Lower plenum dryout & 206.3 & 276.1 & 274.8 \\
\hline $\begin{array}{l}\text { Vessel failure (penetration Ring } \\
\text { No. 1) }\end{array}$ & 274.0 & 338.1 & 306.8 \\
\hline Reactor vessel depressurized & 275.1 & 339.0 & 307.8 \\
\hline Core plate failure in Ring No. 2 & 327.9 & 373.2 & 353.8 \\
\hline Beginning of debris ejection to cav. & 341.2 & 408.2 & 384.0 \\
\hline Core plate failure in Ring No. 3 & 400.4 & 430.0 & 416.5 \\
\hline Drywell failure & 426.0 & 494.0 & 458.8 \\
\hline Deflagrations start in Reactor Bldg. & 426.4 & - & 459.1 \\
\hline Deflagrations end in Reactor Bldg. & 430.8 & -- & 463.6 \\
\hline Lower head penetration fails in Ring No. 2 & 434.9 & 493.2 & 466.7 \\
\hline Deflagrations start in Reactor Bldg. & 441.6 & 494.3 & - \\
\hline Deflagrations end in Reactor Bldg. & 442.4 & 498.4 & - \\
\hline Lower head penetration fails in Ring No. 3 & 441.4 & 499.0 & 471.6 \\
\hline Fission product release ends & 484.9 & 509.2 & 499.6 \\
\hline
\end{tabular}


Sensitivity Calculations

Table 6.12 Impact of Maximum Allowable Timestep Size on Predicted Environmental Releases of Radionuclides

\begin{tabular}{|l|c|c|c|c|}
\hline \multirow{2}{*}{ Class Name } & \multirow{2}{*}{ Representative } & \multicolumn{3}{c|}{ Environmental Release $^{\text {(Fraction) }}$} \\
\cline { 3 - 5 } & & $\Delta t_{\text {max }}=10.03$ & $\Delta t_{\text {max }}=5.08$ & $\Delta t_{\text {max }}=3.03$ \\
\hline Noble Gases & Xe & 0.998 & 0.998 & 0.999 \\
\hline Alkali Metals & Cs & 0.171 & 0.428 & 0.44 \\
\hline Alkaline Earths & $\mathrm{Ba}$ & $4.13 \mathrm{E}-02$ & $2.60 \mathrm{E}-02$ & $4.14 \mathrm{E}-02$ \\
\hline Halogens & $\mathrm{I}$ & $6.79 \mathrm{E}-03$ & $1.02 \mathrm{E}-06$ & $1.09 \mathrm{E}-03$ \\
\hline Chalcogens & $\mathrm{Te}$ & $1.78 \mathrm{E}-02$ & $5.47 \mathrm{E}-02$ & $5.99 \mathrm{E}-02$ \\
\hline Platinoids & $\mathrm{Ru}$ & $8.85 \mathrm{E}-04$ & $4.25 \mathrm{E}-03$ & $7.73 \mathrm{E}-04$ \\
\hline Transition Elements & $\mathrm{Mo}$ & $1.80 \mathrm{E}-02$ & $8.03 \mathrm{E}-03$ & $1.62 \mathrm{E}-02$ \\
\hline Tetravalents & $\mathrm{Ce}$ & $1.88 \mathrm{E}-05$ & $9.93 \mathrm{E}-06$ & $1.85 \mathrm{E}-05$ \\
\hline Trivalents & $\mathrm{La}$ & $8.23 \mathrm{E}-04$ & $4.64 \mathrm{E}-04$ & $4.47 \mathrm{E}-04$ \\
\hline Uranium & $\mathrm{U}$ & $2.97 \mathrm{E}-05$ & $1.56 \mathrm{E}-05$ & $2.74 \mathrm{E}-05$ \\
\hline More Volatile Metals & $\mathrm{Cd}$ & $7.30 \mathrm{E}-02$ & $2.85 \mathrm{E}-02$ & $5.73 \mathrm{E}-02$ \\
\hline Less Volatile Metals & $\mathrm{Sn}$ & $7.38 \mathrm{E}-02$ & $2.88 \mathrm{E}-02$ & $5.81 \mathrm{E}-02$ \\
\hline Boron & $\mathrm{B}$ & 0.0 & 0.0 & 0.0 \\
\hline Water & $\mathrm{H} \mathrm{O}$ & 0.0 & 0.0 & 0.0 \\
\hline Concrete & - & 0.0 & 0.0 & 0.0 \\
\hline Cesium Iodide & $\mathrm{CsI}$ & $8.56 \mathrm{E}-02$ & 0.365 & 0.462 \\
\hline
\end{tabular}




\section{Conclusions}

This report has documented the results from MELCOR calculations of the Long-Term Station Blackout Accident Sequence, with failure to depressurize the reactor vessel, at the Peach Bottom (BWR Mark I) plant, and has presented comparisons with Source Term Code Package calculations of the same sequence. The results include the release of source terms to the environment.

While MELCOR and STCP calculate similar overall timing of key events and similar peak core temperatures, the more sophisticated modeling in MELCOR allows it to calculate more gradual melting and relocation of core materials and failure of the reactor vessel that is staggered over a much longer time period. Failure of the reactor vessel leads to rapid pressurization of both the drywell and wetwell, but the pressure stays below the nominal failure level, and containment failure is calculated to occur late, due to the combination of an elevated suppression pool temperature and the buildup of non-condensible gas. STCP calculations show similar trends. Failure of the primary containment is followed shortly by several hydrogen burns in the reactor building and refueling bay. Their timings relative to containment failure are similar for both MELCOR and STCP. The predicted duration of deflagration is longer for MELCOR than for STCP, because the MELCOR plant model considers many compartments in the reactor building, with delays in burn propagation from one compartment to the next, while STCP models the entire reactor building as one volume.

A comparison of environmental releases between MELCOR and STCP reveals significant differences. MELCOR predicts much lower environmental release fractions of $\mathrm{Sr}, \mathrm{La}, \mathrm{Ce}$, and $\mathrm{Ba}$, and STCP predicts lower fractions of I, Cs, and Ru. MELCOR and STCP predict similar release and retention of $I$ and $C s$ from the fuel during in-vessel core meltdown; however, the higher environmental release fractions of I and Cs from MELCOR can be attributed to late revaporization from the RCS after the core debris penetrates the reactor vessel. This phenomenon is not modeled in STCP, and, therefore, the revaporization model in MELCOR represents an important advance in modeling capability. Note that since Te is mostly released during core/concrete interactions, the revaporization of Te from the RCS has no impact on its total release to the environment. The lower refractory releases is because MELCOR calculates debris ejection into the cavity over a much longer period of time, based on successive penetration failures in the three rings, while STCP assumes the release of all of the core at the time of vessel breach. The MELCOR meltdown model, therefore, results in less vigorous core concrete interactions than STCP, leading to lower release of the fission products associated with this phase of the accident. These two models represent credible variations on possible core meltdown configurations and should be taken into account as part of an uncertainty study.

The selection of $\Delta t_{\text {max }}$ and its impact on the calculational behavior of MELCOR was explored as part of a limited sensitivity analysis for the Station Blackout simulation using MELCOR Version 1.8BC, by selecting two variations, i.e., $\Delta t_{\max }=5 \mathrm{sec}$ and $3 \mathrm{sec}$, and comparing the predicted results with the reference calculation, which used $\Delta t_{\max }=10 \mathrm{sec}$. Both variations were seen to delay the occurrence of most key events compared to the reference calculation and to substantially increase the release of $\mathrm{Cs}$ and I to the environment. The 5 sec case gave the largest deviation in timing. The disparity in predicted results could be partially attributed to the way MELCOR calculates several key events based on threshold values of temperature or pressure.

Subsequent to the preparation of the draft report, a newer version of the code, 1.8DN, was released to users. This version, with corrected routines CORAC4 and CORRN3 compiled and linked to it, was installed on BNL's VAX computer and renamed version 1.8DNX. The impact of $\Delta t_{\max }$ on calculated results for Peach Bottom was re-examined, using the improved MELCOR Version 1.8DNX (Appendix B). Complete sequence calculations were carried out selecting five variations of $\Delta t_{\max }(10,5,3,2$, and $1 \mathrm{sec})$. Examination of vessel failure and drywell failure timings showed that reducing $\Delta t_{\max }$ from $10 \mathrm{sec}$ to $1 \mathrm{sec}$ did not lead to a converged solution, even with the improved code version. The failure times were seen to alternately increase and decrease as $\Delta t_{\text {max }}$ was reduced. The maximum uncertainty in environmental release fractions was a factor of seven (for $\mathrm{Ru}$ ) and within a factor of four for the rest of the radionuclides over the entire range of $\Delta t_{\text {max }}$ 
Finally, it was observed that when BNL's VAX operating system was upgraded from VMS version 5.3-1 to version 5.4-1A, there were substantial differences in calculated results of the same sequence for $\Delta t_{\max }=1 \mathrm{~s}$, 2s, and 5s. In fact, for the $5 \mathrm{~s}$ case, the initial pressure spike after vessel failure was sufficient to fail the containment early. This sensitivity of the code calculations to changes in the operating system raise questions regarding portability of the code. However, such problems are not limited to MELCOR, but would be expected to plague all large computer codes.

These findings were reported to the NRC, SNL, and the MELCOR Peer Review Committee. This alerted the NRC, the code developers, and the MELCOR Peer Reviewers to the importance of correcting the numerical sensitivities. As a consequence, a significant effort was undertaken to eliminate or mitigate these sensitivities. The latest released version of MELCOR, Version 1.8.2, released in April 1993, contains several new or improved models, and has corrections to mitigate numerical sensitivities [21].

In order to update the earlier sensitivity studies on maximum timestep, to more properly represent the abilities of the improved MELCOR version 1.8.2, complete sequence calculations were carried out using MELCOR 1.8.2 and the current Peach Bottom input deck, once again selecting five variations of $\Delta t_{\max }(10,5$, 3,2 , and 1 sec).

The Peach Bottom input deck has evolved since the study with MELCOR 1.8DNX, mainly in response to code changes and improvements, but also with the inclusion of a radiation option for in-vessel heat structures. The current deck has most of the new models available in MELCOR 1.8.2 activated, such as eutectic interactions, in-vessel radial relocation of debris, in-vessel falling debris quench model, and boundary fluid temperature option. While there was no convergence of the solution in going to a smaller $\Delta t_{\text {mes }}$ there was clearly very close agreement in the timing of key events. In most cases, the deviations in timing were limited to a few hundred seconds. Earlier calculations using MELCOR 1.8DNX showed much larger deviations, many as high as 10,000 seconds. This is certainly evidence of improved numerical behavior of MELCOR 1.8.2. The maximum deviation in release fractions was a factor of 2 , while the deviation for most of the radionuclides was much less than that. This is again a significant improvement over the earlier results using MELCOR 1.8DNX.

A few points worth noting are listed below (See Appendix $C$ for details):

1. All calculations shown here resulted in early drywell failure. In comparison, earlier calculations with MELCOR 1.8DNX resulted in delayed drywell failure.

2. Activation of the new radial debris relocation models in MELCOR 1.8.2, caused vessel (penetration) failures in all 3 radial rings to occur much closer together. Earlier calculations using MELCOR $1.8 \mathrm{DNX}$ showed staggering of penetration failures in different rings by as much as 13,000 sec.

MELCOR 1.8.2 contains several new or improved models that add to its modeling capabilities. One of them is the falling debris quench model. When activated, this model allows the debris to lose heat to surrounding water in the lower plenum as it falls to the lower head, following failure of the core support plate in each radial ring. An examination of the new falling debris quench model showed that, with proper input parameter selection, this model allows better representation of falling debris quench behavior.

Another new model, available to users as an option with MELCOR version 1.8.2, is the BH model. The BH package mechanistically calculates the thermal response of the lower plenum debris, the heatup of the reactor vessel bottom head, and the release of core and structural materials from the reactor vessel to the drywell. Implementation of this model in MELCOR 1.8.2 calculations for Peach Bottom showed that compared with results using the standard MELCOR lower head model, all events were slightly delayed (except for debris ejection to cavity). This delay is consistent with calculations reported by ORNL for LaSalle [24]. Once again, there was early drywell failure shortly after vessel (penetration) failure. The model also allows calculation of global bottom head failure due to creep rupture, at which time all remaining debris in the lower plenum is transferred to the drywell. 
As of this study, the BH package was still undergoing extensive additional development at ORNL. When the integration of ORNL's new BH model into MELCOR is complete, this model will certainly add more sophisticated capability to MELCOR's lower head modeling for BWRs. 


\section{References}

1. R. S. Denning, et al., "Radionuclide Release Calculations for Selected Severe Accident ScenariosBWR, Mark I Design," NUREG/CR-4624, BMI-2139, Vol. 1, July 1986.

2. R. M. Summers, et al., "MELCOR 1.8.0: A Computer Code for Severe Nuclear Reactor Accident Source Term and Risk Assessment Analyses," NUREG/CR-5531, SAND90-0364, January 1991.

3. J. A. Gieseke, et al., "Source Term Code Package: A User's Guide," NUREG/CR-4587, BMI-2138, April 1986.

4. G. Wade, "Evolution and Current Status of the BWR Containment System," Nuclear Safety, Vol. 15, No. 2, 1974.

5. J. N. Castle, et al., "State of the Art of Reactor Containment Systems, Dominant Failure Modes, and Mitigation Opportunities," RDA-TR-127301-001, January 1984.

6. S. R. Greene, "Realistic Simulation of Severe Accidents in BWRs-Computer Modeling Requirements, "NUREG/CR-2940, ORNL/TM-8517, April 1984.

7. Peach Bottom Updated Final Safety Analysis Report, Vol. 1, Philadelphia Electric Company, 1989.

8. M. Silberberg, et al., "Reassessment of the Technical Bases for Estimating Source Terms," NUREG0956, July 1986.

9. "Severe Accident Risks: An Assessment for Five U.S. Nuclear Power Plants," NUREG-1150, Vol. 1, December 1990.

10. Reactor Risk Reference Report, Draft for Comment, NUREG-1150, Vol. 1, February 1987.

11. R. M. Summers, et al., "MELCOR In-Vessel Modeling," Proceedings of the Fifteenth Water Reactor Safety Information Meeting, NUREG/CP-0090, p. 384, October 1987.

12. M. R. Kuhlman, et al., "CORSOR User's Manual," NUREG/CR-4173, BMI-2122, March 1985.

13. D. A. Powers, et al., "VANESA, A Mechanistic Model of Radionuclide Release and Aerosol Generation During Core Debris Interactions with Concrete," NUREG/CR-4308, SAND85-1370, 1986.

14. F. Gelbard, "MAEROS User Manual," NUREG/CR-1391, SAND80-0822, 1982.

15. H. Jordan and M. R. Kuhlman, "TRAP-MELT2 User's Manual," NUREG/CR-4205, BMI-2124, 1985.

16. L. G. Greimann, et al., "Reliability Analysis of Steel Containment Strength," Iowa State University, NUREG/CR-2442, June 1982.

17. I.K. Madni, Letter Report to R. Foulds, February 1991.

18. I.K. Madni, Letter Report to R. Summers, April 1991.

19. I.K. Madni, Letter Report to R. Summers, April 1991.

21. MELCOR 1.8.2 Users' Guide/Reference Manual, Sandia National Laboratories, February 1993. 
23. I.K. Madni, "Melcor 1.8.2 Anlayses of In-Vessel Structure Temperatures and Debris Ejection Characteristics During a Low-Pressure Station Blackout in Peach Bottom, " Draft Report A-3281, SRED-16, Brookhaven National Laboratory, June 11, 1993.

24. S.A. Hodge, et. al., "BWR-Specific Models for MELCOR," presented at the 1993 CSARP Review Meeting, Bethesda, MD, May 3-7, 1993.

25. C.R. Hyman and R.L. Sanders, "BH Package Users' Guide, Version 1.0.3," Oak Ridge National Laboratory, December 31, 1992. 


\section{Appendix A}

\section{Comparison of Results with MELCOR 1.8BC and MELCOR 1.8CZ}

MELCOR version 1.8.0 was released in March 1989. MELCOR 1.8BC was released as an interim version and installed on BNL's VAX computer in November 1989. This version incorporates updates 1.8AA through $1.8 \mathrm{BC}$ in response to Defect Investigation Reports (DIRs) submitted by users and the developers and has been the version used, together with a few patches to correct new, post-1.8BC code errors uncovered while conducting the Peach Bottom analyses, for all the calculations presented in this report. Subsequently, MELCOR 1.8CZ, which incorporates additional updates through $1.8 \mathrm{CZ}$, was received in April 1990.

Tables A.1 and A.2 present a comparison of the accident progression timing and release of source terms to the environment, respectively, calculated by MELCOR 1.8BC (reference calculation) and MELCOR 1.8CZ. MELCOR $1.8 \mathrm{CZ}$ is seen to predict vessel failure to occur about $\mathbf{4 0}$ minutes earlier and drywell failure to occur over 1.5 hours earlier than the reference calculation. Also, MELCOR $1.8 \mathrm{CZ}$ calculates consistently higher releases of source terms to the environment, but most of the differences are within a factor of two of each other. 
Appendix A

Table A.1 Comparison of Timing of Key Events Predicted by MELCOR 1.8BC and MELCOR 1.8CZ

\begin{tabular}{|c|c|c|}
\hline \multirow{2}{*}{ Key Event } & \multicolumn{2}{|c|}{ Time (min) } \\
\hline & MELCOR 1.8BC & MEUCOR $1.8 \mathrm{CZ}$ \\
\hline Core uncovery & 0.0 & 0.0 \\
\hline Fission product release from gap in Ring No. 1 & 76.8 & 78.1 \\
\hline Fission product release from gap in Ring No. 2 & 85.4 & 86.3 \\
\hline Fission product release from gap in Ring No. 3 & 116.4 & 136.8 \\
\hline Core plate failure in Ring No. 1 & 154.4 & 160.3 \\
\hline Lower plenum dryout & 206.3 & 185.5 \\
\hline Vessel failure (penetration Ring No. 1) & 274.0 & 232.0 \\
\hline Reactor vessel depressurized & 275.1 & 232.9 \\
\hline Core plate failure in Ring No. 2 & 327.9 & 137.3 \\
\hline Beginning of debris ejection to cav. & 341.2 & 306.7 \\
\hline Core plate failure in Ring No. 3 & 400.4 & 346.4 \\
\hline Drywell failure & 426.0 & 328.9 \\
\hline Deflagrations start in secondary containment & 426.4 & 330.1 \\
\hline Deflagrations end in secondary containment & 430.8 & 335.5 \\
\hline Lower head penetration fails in Ring No. 2 & 434.9 & 254.1 \\
\hline Deflagrations start in Reactor Bldg. & 441.6 & $\cdots$ \\
\hline Deflagrations end in Reactor Bldg. & 442.4 & $\cdots$ \\
\hline Lower head penetration fails in Ring No. 3 & 441.4 & 458.4 \\
\hline Fission product release ends & 484.9 & 765.8 \\
\hline
\end{tabular}


Table A.2 Comparison of Environmental Rolease of Source Terms Predicted by MELCOR 1.8BC and MRTCOR 1.8CZ

\begin{tabular}{|c|c|c|c|}
\hline \multirow{2}{*}{ Class Name } & \multirow{2}{*}{ Representative } & \multicolumn{2}{|c|}{$\begin{array}{c}\text { Environmental Release } \\
\text { (Fraction) } \\
\end{array}$} \\
\hline & & METCOR 1.8BC & MELCOR $1.8 \mathrm{CZ}$ \\
\hline Noble Gases & $\mathbf{X e}$ & 0.998 & 0.999 \\
\hline Alkali Metals & Cs & 0.171 & 0.169 \\
\hline Alkaline Earths & $\mathbf{B a}$ & 4.13E-02 & 7.87E-02 \\
\hline Halogens & I & $6.79 \mathrm{E}-03$ & $9.26 \mathrm{E}-03$ \\
\hline Chalcogens & $\mathrm{Te}$ & $1.78 \mathrm{E}-02$ & $6.56 \mathrm{E}-02$ \\
\hline Platinoids & $\mathbf{R u}$ & 8.85E-04 & $2.02 \mathrm{E}-03$ \\
\hline Transition Elements & Mo & $1.80 \mathrm{E}-02$ & 4.57E- 02 \\
\hline Tetravalents & $\mathrm{Ce}$ & $1.88 \mathrm{E}-05$ & $5.40 \mathrm{E}-05$ \\
\hline Trivalents & $\mathbf{L a}$ & 8.23E-04 & 8.08E-04 \\
\hline Uranium & $\mathbf{U}$ & $2.97 \mathrm{E}-05$ & $7.42 \mathrm{E}-05$ \\
\hline More Volatile Metals & $\mathrm{Cd}$ & $7.30 \mathrm{E}-02$ & 0.133 \\
\hline Less Volatile Metals & $\mathrm{Sn}$ & 7.38E-02 & 0.145 \\
\hline Boron & B & 0.0 & 0.0 \\
\hline Water & $\mathrm{H}_{2} \mathrm{O}$ & 0.0 & 0.0 \\
\hline Concrete & - & 0.0 & 0.0 \\
\hline Cesium Iodide & CsI & $8.56 \mathrm{E}-02$ & 0.11 \\
\hline
\end{tabular}




\section{Appendix B}

\section{Additional Calculations and Findings from MELCOR 1.8DNX}

\section{B.1 Impact of Maximum Allowable Timestep ( $\Delta \mathrm{t}_{\max }$ ) on Peach Bottom Station Blackout Calculations Using MELCOR 1.8DNX [17]}

Subsequent to the preparation of the draft report entitled, "Analysis of Long-Term Station Blackout Without Automatic Depressurization at Peach bottom Using MELCOR (Version 1.8)," a newer version of the code, 1.8DN, was released to users. This version, with corrected routines CORAC4 (DIR-BNL-23) and CORRN3 (DIR-BNL-22) compiled and linked to it, was installed on BNL's VAX computer and renamed version 1.8DNX. Note that an error in CORRN3 had caused the mass inconsiatencies in debris ejection to cavity.

The impact of $\Delta t_{(m)}$ on calculated results for Peach Bottom was re-examined, using MELCOR Version $1.8 D N X$. Complete sequence calculations were carried out selecting five variations of $\Delta t_{\text {(ma }}(10,5,3,2$, and $1 \mathrm{sec})$. The reference case corresponds to $\Delta t_{\text {(max }}=10 \mathrm{sec}$.

Table B.1 presents MELCOR-calculated timing of key events. Examination of vessel failure and drywell failure timings, for example, clearly shows that reducing $\Delta t_{\text {(m) }}$ from $10 \mathrm{sec}$ to $1 \mathrm{sec}$ does not lead to a converged solution, even with the improved version. The failure times are seen to alternately increase and decrease as $\Delta t_{(\text {max }}$ is reduced. The disparity in predicted results could be partially attributed to the way MELCOR calculates several key events based on threshold values of temperature or pressure. This uncertainty in results based on a calculational parameter indicates the need for further investigation of the solution algorithm and guidelines on selection of the most appropriate $\Delta t_{\text {(exa), }}$, to minimize this uncertainty. The development staff at SNL have indicated their awareness of this problem and would prefer if the cause could be detected and treated by the internal timestep algorithm.

Figures B.1 through B.3 show MELCOR-calculated debris ejection characteristics to the cavity. The stepwise behavior corresponds to ejection of debris following successive penetration failures in radial rings 1,2 , and 3. Any additional steps in ejection are an artifact of the semi-mechanistic melt progression and core relocation model in MELCOR. The ejection characteristics are very similar for $\Delta t_{(\max )}=10,5$, and 3 sec, except for the differences in ejection timing.

Table B.2 presents MELCOR-calculated environmental releases of radionuclides. It is observed that, while there is no converged solution, the maximum uncertainty in release fraction is a factor of seven (for $\mathbf{R u}$ ), while release fractions for the majority of radionuclides lie within a factor of four of each other over the entire range of $\Delta t_{(\max )}$.

Note that $\Delta t$ is problem dependent and the most appropriate $\Delta t_{\text {(max) }}$ can vary from one plant simulation to another, from one sequence to another, and within a sequence, from one stage of the transient to another. This implies that some user involvement in the selection of the most appropriate $\Delta t_{\text {(max) }}$ may be unavoidable. 
Appendt B

Table B.1 Impect of Maximum Allowrable Timetop Size on Predicted Timing of Key Events (MELCOR Vorsion 1.8DNX)

\begin{tabular}{|c|c|c|c|c|c|}
\hline \multirow[b]{2}{*}{ Key Evont } & \multicolumn{5}{|c|}{$\operatorname{Tm}(\boldsymbol{m e c})$} \\
\hline & $\Delta t_{(m)}=10 s$ & $\Delta t_{(\operatorname{man})}=S_{0}$ & $\Delta t_{(-1)}=3 s$ & $\Delta t_{(\operatorname{man})}=20$ & $\Delta t_{(\operatorname{mon})}=1 \mathrm{~s}$ \\
\hline Core uncovery & 0.0 & 0.0 & 0.0 & 0.0 & 0.0 \\
\hline $\begin{array}{l}\text { Fisesion product release } \\
\text { from gap in Ring No. } 1\end{array}$ & $4,617,3$ & $4,794.1$ & $4,509.4$ & $4,520.3$ & $4,543.7$ \\
\hline $\begin{array}{l}\text { Fission product release } \\
\text { from gap in Ring No. } 2 \\
\end{array}$ & $5,103.0$ & $5,289.5$ & $5,029.7$ & $5,050.4$ & $5,076.9$ \\
\hline $\begin{array}{l}\text { Finsion product release } \\
\text { from gap in Ring No. } 3\end{array}$ & $6,820.0$ & $8,485.5$ & $9,057.0$ & $8,758.5$ & $9,456.3$ \\
\hline $\begin{array}{l}\text { Core plate fallure in Ring } \\
\text { No. } 1\end{array}$ & $9,491.6$ & $9,338.4$ & $9,757.0$ & $10,393.6$ & $10,295.3$ \\
\hline Lower plenum dryout & $16,636.1$ & $12,534.5$ & $15,639.2$ & $10,609.2$ & $21,693.5$ \\
\hline $\begin{array}{l}\text { Vessel failure } \\
\text { (penetration Ring No 1) }\end{array}$ & $19,924.1$ & $14,234.5$ & $18,261.2$ & $\begin{array}{c}13,737.2 \\
. \\
\end{array}$ & $23,734.5$ \\
\hline $\begin{array}{l}\text { Reactor vessel } \\
\text { depresourized }\end{array}$ & $19,980.0$ & $14,298.6$ & $18,318.2$ & $13,803.2$ & $23,786.5$ \\
\hline $\begin{array}{l}\text { Core plate failure in Ring } \\
\text { No. } 2\end{array}$ & $22,310.2$ & $19,627.0$ & $21,072.7$ & $9,379.2$ & $25,325.5$ \\
\hline $\begin{array}{l}\text { Beginning of debris } \\
\text { ejection to cavity }\end{array}$ & $24,690.2$ & $18,817.1$ & $23,095.0$ & $18,184.4$ & $28,796.5$ \\
\hline $\begin{array}{l}\text { Core plate failure in Ring } \\
\text { No. } 3\end{array}$ & $25,480.2$ & $22,920.0$ & $24,307.0$ & $19,964.5$ & $28,289.5$ \\
\hline $\begin{array}{l}\text { Lower head penetration } \\
\text { fails in Ring No. } 2\end{array}$ & $26,930.2$ & $25,668.0$ & $24,688.0$ & $14,538.4$ & $31,026.7$ \\
\hline Drywell failure & $28,923.0$ & $22,777.1$ & $26,344.0$ & $19,376.4$ & $30,417.2$ \\
\hline $\begin{array}{l}\text { Deflagrations start in } \\
\text { Reactor Building }\end{array}$ & $28,935.4$ & $22,752.0$ & $26,347.0$ & $19,421.8$ & $30,420,8$ \\
\hline $\begin{array}{l}\text { Deflagrations end in } \\
\text { Reactor Building }\end{array}$ & $28,995.2$ & $22,837.0$ & $26,400.6$ & $19,481.1$ & $30,479.3$ \\
\hline $\begin{array}{l}\text { Lower head penetration } \\
\text { fails in Ring No. } 3\end{array}$ & $29,136.9$ & $27,249.0$ & $26,828.0$ & $21,133.1$ & $32,088.7$ \\
\hline $\begin{array}{l}\text { Deflagrations start in } \\
\text { Reactor Building }\end{array}$ & $47,416.6$ & $41,400.0$ & $46,760.1$ & $\$ 6,094.7$ & $52,926.5$ \\
\hline $\begin{array}{l}\text { Deflagrations end in } \\
\text { Reactor Building }\end{array}$ & $51,452.0$ & $44,236.0$ & $53,141.5$ & $46,109.5$ & $54,243.0$ \\
\hline $\begin{array}{l}\text { Fission product rolease } \\
\text { ends }\end{array}$ & $49,576.0$ & $28,229.0$ & $48,828.1$ & & $33,261.7$ \\
\hline
\end{tabular}




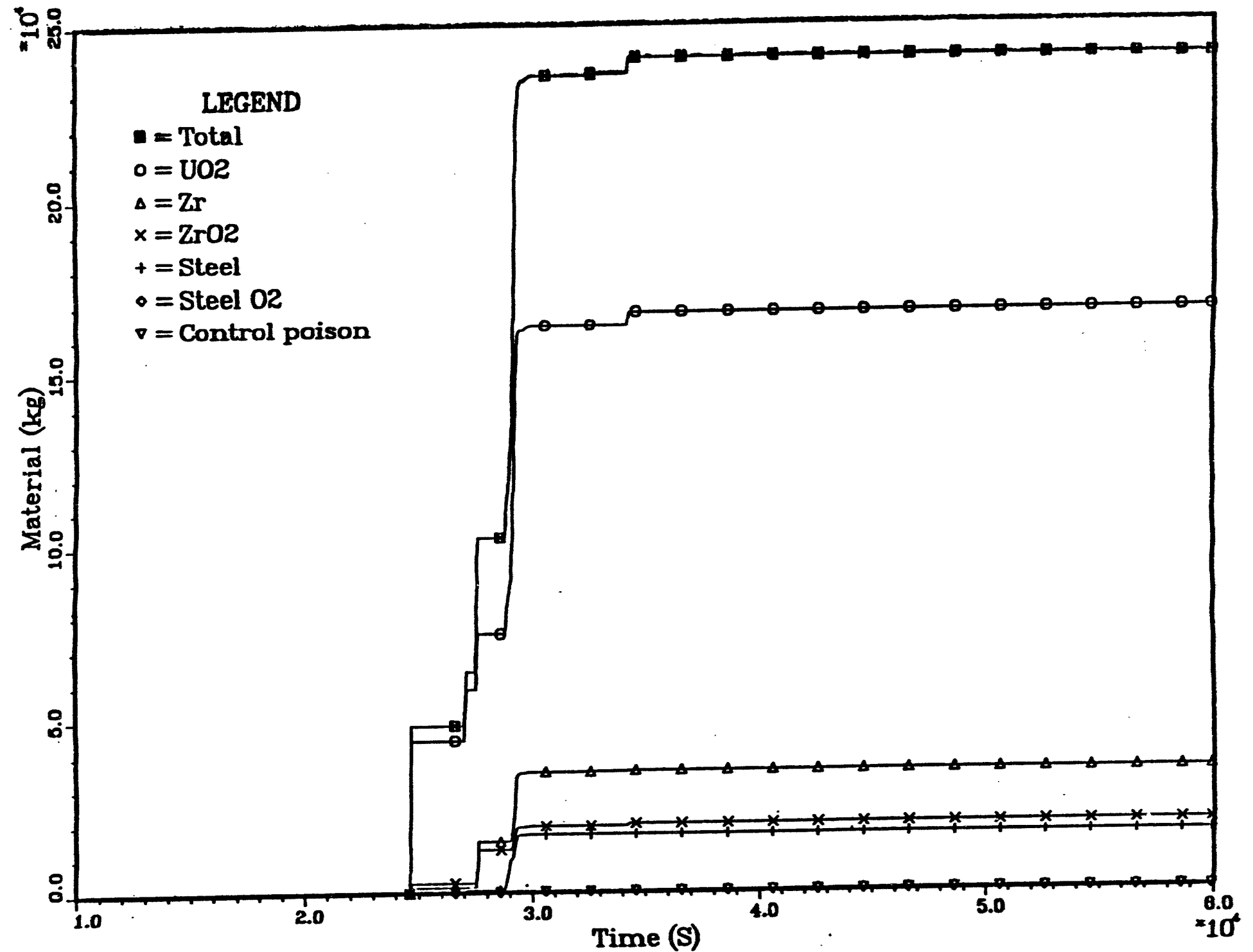

FIG. B.1. Material ejected to CAV as calculated by MELCOR, $\Delta t_{\max }=10 \mathrm{~S}$ 


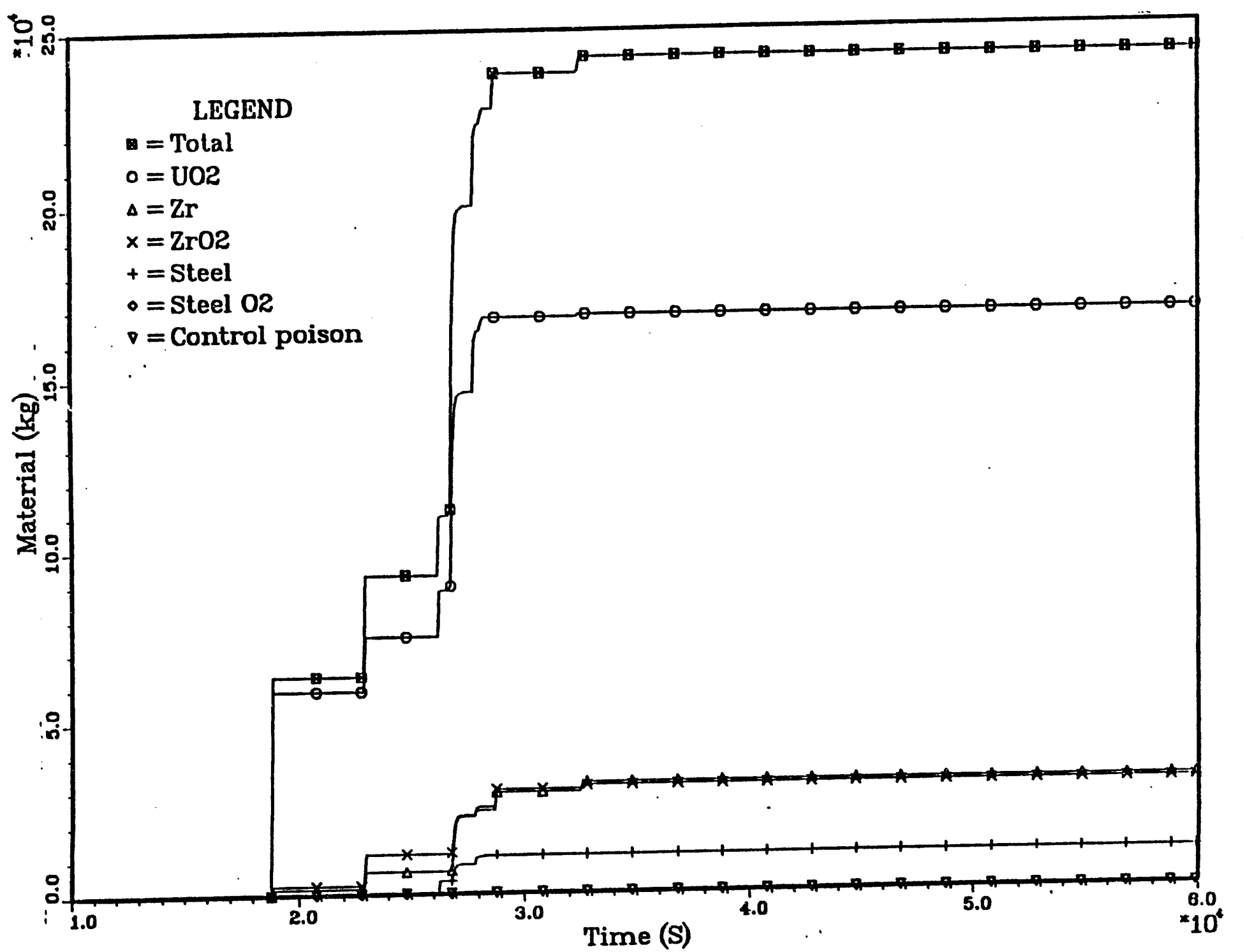

FIG. B.2. Material ejected to CAV as calculated by MELCOR, $\Delta t_{\max }=5 \mathrm{~S}$ 


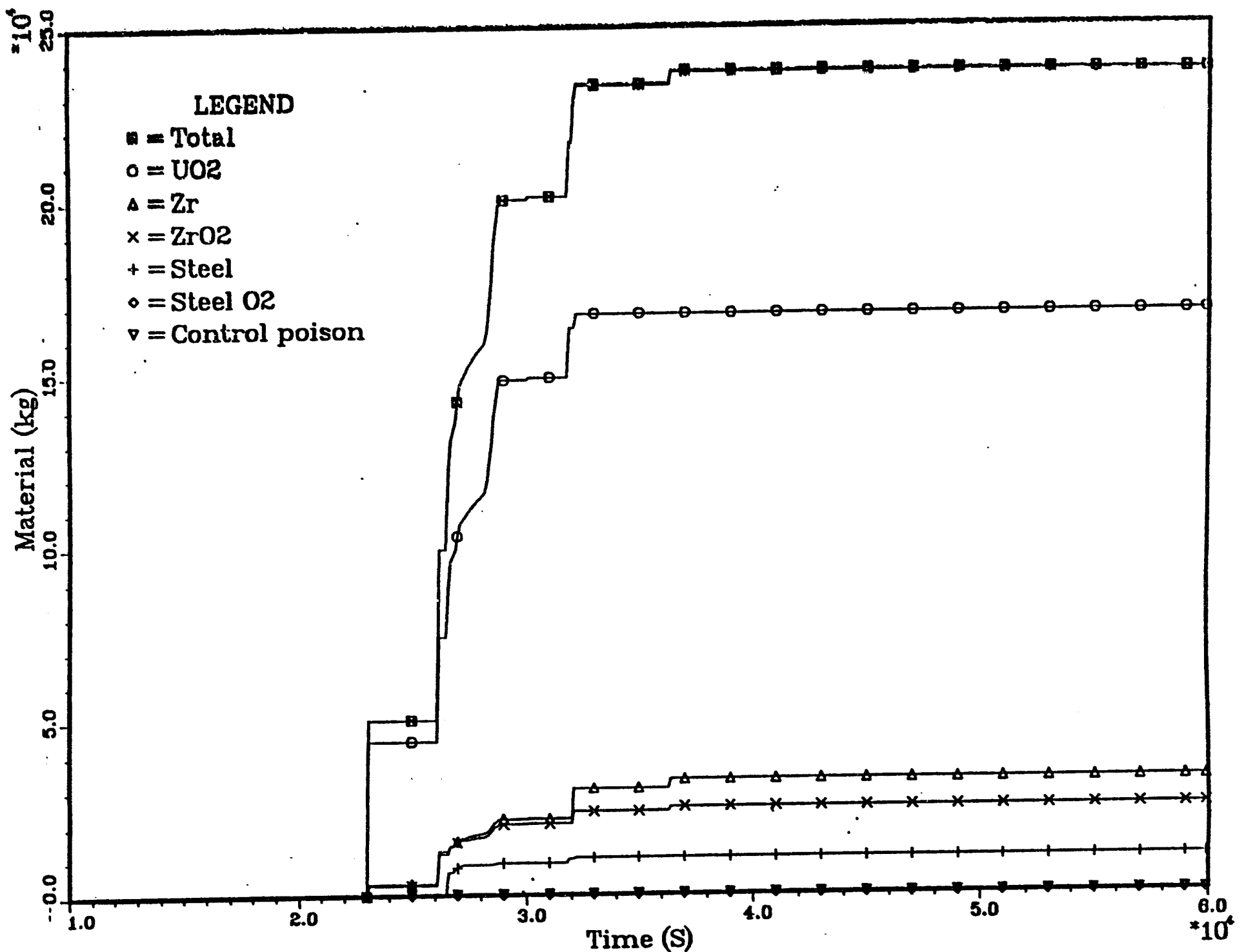

FIG. B.3. Material ejected to CAV as calculated by ḾELCOR, $\Delta t_{\max }=3 \mathrm{~S}$ 
Appendix B

Table B.2 Impact of Maximum Allowable Timestep Size on

Predicted Environmental Releases of Radionuclides (MIRLCOR Version 1.8DNX)

\begin{tabular}{|c|c|c|c|c|c|}
\hline \multirow[b]{2}{*}{ Class } & \multicolumn{5}{|c|}{ Environmental Release (Fraction) } \\
\hline & $\Delta t_{(\max )}=10 s$ & $\Delta t_{(\max )}=5 s$ & $\Delta t_{(\max )}=3 s$ & $\Delta t_{(\max )}=2 s$ & $\Delta t_{(\max )}=1 \mathrm{~s}$ \\
\hline $\mathrm{Xe}$ & $9.97 \mathrm{E}-01$ & $9.97 \mathrm{E}-01$ & $9.97 \mathrm{E}-01$ & $9.96 \mathrm{E}-01$ & $9.91 \mathrm{E}-01$ \\
\hline Cs & 2.63E-01 & $1.53 \mathrm{E}-01$ & $3.53 \mathrm{E}-01$ & $2.40 \mathrm{E}-01$ & $3.18 \mathrm{E}-01$ \\
\hline $\mathbf{B a}$ & 2.37E-01 & 3.15E-01 & $2.91 \mathrm{E}-01$ & $7.88 \mathrm{E}-02$ & $2.20 \mathrm{E}-01$ \\
\hline $\mathrm{Te}$ & 1.91E-01 & $2.27 \mathrm{E}-01$ & $2.49 \mathrm{E}-01$ & $1.01 E-01$ & $1.49 \mathrm{E}-01$ \\
\hline $\mathbf{R u}$ & 4.57E-04 & 3.20E-03 & $1.42 \mathrm{E}-03$ & 8.85E-04 & $1.34 \mathrm{E}-03$ \\
\hline Mo & $1.63 \mathrm{E}-02$ & $6.68 \mathrm{E}-02$ & 2.75E-02 & $2.67 \mathrm{E}-02$ & $3.54 \mathrm{E}-02$ \\
\hline $\mathrm{Ce}$ & 1.33E-05 & 8.31E-05 & $3.36 \mathrm{E}-05$ & $1.80 \mathrm{E}-05$ & $1.81 \mathrm{E}-05$ \\
\hline $\mathrm{La}$ & 7.44E-03 & 7.63E-03 & $6.94 \mathrm{E}-03$ & $3.99 \mathrm{E}-04$ & $4.39 \mathrm{E}-03$ \\
\hline $\mathbf{U}$ & 3.53E-05 & $1.35 \mathrm{E}-04$ & $6.46 \mathrm{E}-05$ & 2.86E-05 & 4.52E-05 \\
\hline $\mathrm{Cd}$ & $3.92 \mathrm{E}-02$ & $1.88 \mathrm{E}-01$ & $1.08 \mathrm{E}-01$ & $7.09 \mathrm{E}-02$ & 1.12E-01 \\
\hline Sn & $5.78 \mathrm{E}-02$ & 2.13E-01 & 1.31E-01 & $8.36 \mathrm{E}-02$ & $1.26 \mathrm{E}-01$ \\
\hline B & 0.0 & 0.0 & 0.0 & 0.0 & 0.0 \\
\hline $\mathrm{H}_{2} \mathrm{O}$ & 0.0 & 0.0 & 0.0 & 0.0 & 0.0 \\
\hline Concrete & 0.0 & 0.0 & 0.0 & 0.0 & 0.0 \\
\hline CsI & $2.96 \mathrm{E}-01$ & 2.78E-01 & $4.80 \mathrm{E}-01$ & $1.49 \mathrm{E}-01$ & $4.92 \mathrm{E}-01$ \\
\hline
\end{tabular}




\section{B.2 Examination of Lower Plenum Dryout Times as Calculated by MELCOR, Version 1.8DNX [18]}

Table B.3 presents the interval between core plate failure and lower plenum dryout calculated by MELCOR for various values of $\Delta t_{(\max )}$. These numbers were derived from Table B.1. Note that the dryout times correlate well with the masses of fuel and other debris that are relocated to the lower plenum following core plate failure. Debris masses are also presented in Table B.3. The remarkably short dryout time for the $2 \mathrm{~s}$ case can be attributed to core plate failure in Rings 1 and 2, thus relocating a much larger debris mass to the lower plenum.

For the $\Delta t_{(\max }=10 \mathrm{~s}$ case, which serves as the reference, the 7144s dryout time can be divided into an initial 180 s, during which the hot debris gets quenched and boils off about half of the water inventory in the lower plenum, and about $7000 \mathrm{~s}$, when the remaining water boils off gradually due to decay heating. These observations were made from Figure B.4, which shows water mass in the lower plenum vs. time, and Figure B.5, where the time scale has been magnified to show clearly the quench duration.

The above investigation on dryout time was carried out following telephone conversations with $\mathrm{C}$. Tinkler, NRC. 
Appendix B

Table B.3 Core Debris Relocation and Lower Plenum Dryout Times for Various $\Delta t_{\text {(max) }}$ (MELCOR Version 1.8DNX*)

\begin{tabular}{|c|c|c|c|c|c|c|}
\hline \multicolumn{2}{|c|}{$\Delta t_{\text {(max) }}$} & 10s & 5s & 3s & $2 s$ & 1s \\
\hline \multicolumn{2}{|c|}{$\begin{array}{l}\text { LP dryout time after core } \\
\text { plate fails }\end{array}$} & $7,144 \mathrm{~s}$ & $3,196 \mathrm{~s}$ & $5,882 \mathrm{~s}$ & $1,230 \mathrm{~s}$ & $11,398 \mathrm{~s}$ \\
\hline \multicolumn{7}{|c|}{ Debris mass relocated to LP during first 20,000 s $(\mathrm{kg})$} \\
\hline \multirow{5}{*}{ Ring 1} & Fuel & 44,300 & 59,000 & 44,000 & 59,000 & 29,000 \\
\hline & Steel & & 12,200 & 10,600 & 2,400 & 10,500 \\
\hline & Steel $\mathbf{O x}$ & & 750 & 1,380 & 300 & 1,475 \\
\hline & $\mathbf{Z r}$ & 1,360 & 1,600 & 3,200 & 2,600 & \\
\hline & $\mathrm{ZrO}_{2}$ & 2,450 & 2,500 & 2,700 & 4,000 & \\
\hline \multirow{5}{*}{ Ring 2} & Fuel & & & & 42,500 & \\
\hline & Steel & & & & 5,700 & \\
\hline & Steel Ox & & & & 200 & \\
\hline & $\mathbf{Z r}$ & & & & 3,500 & \\
\hline & $\mathrm{ZrO}_{2}$ & & & & 2,250 & \\
\hline
\end{tabular}

*Operating System: VAX/VMX Version 5.3-1. 


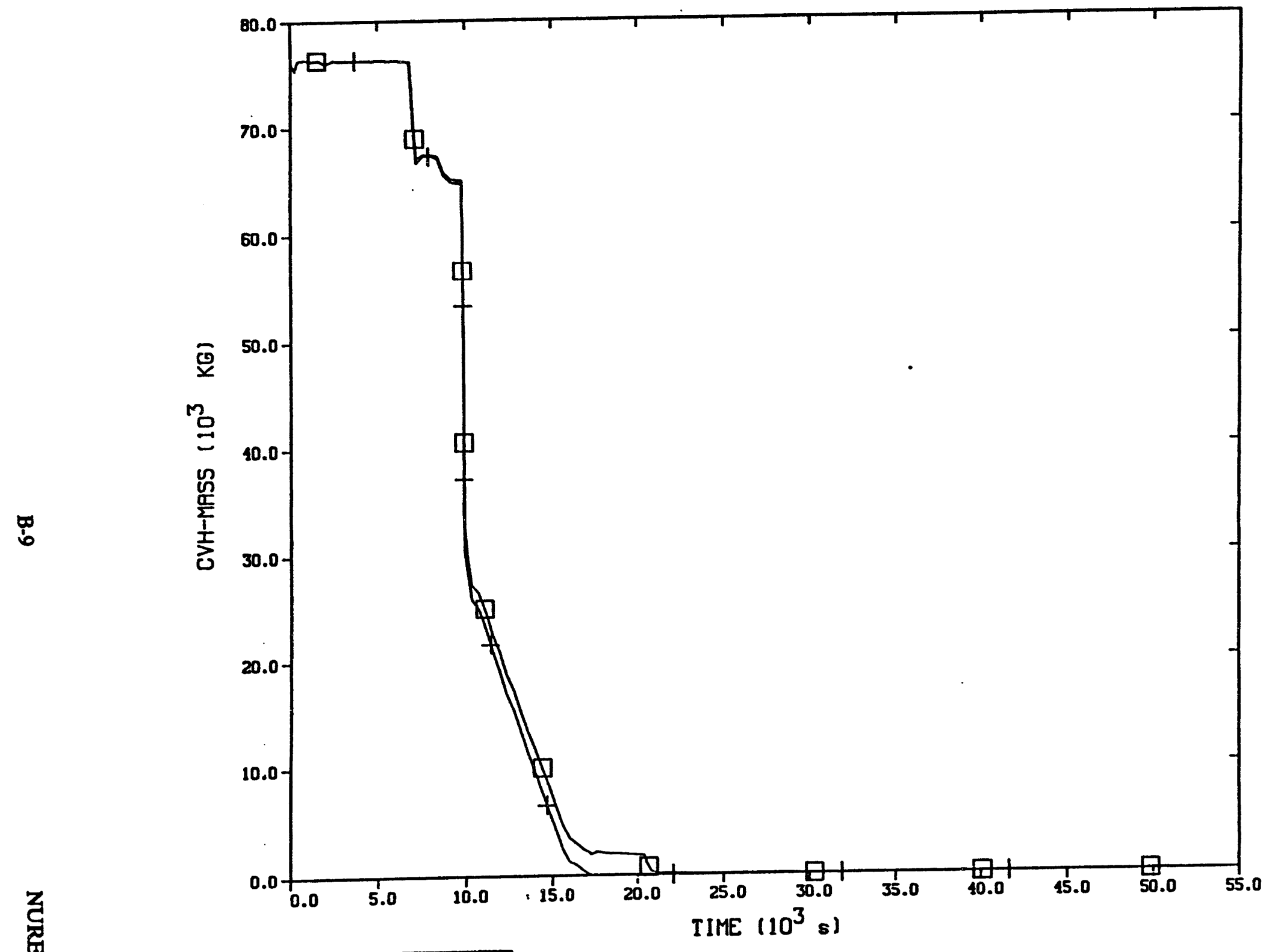




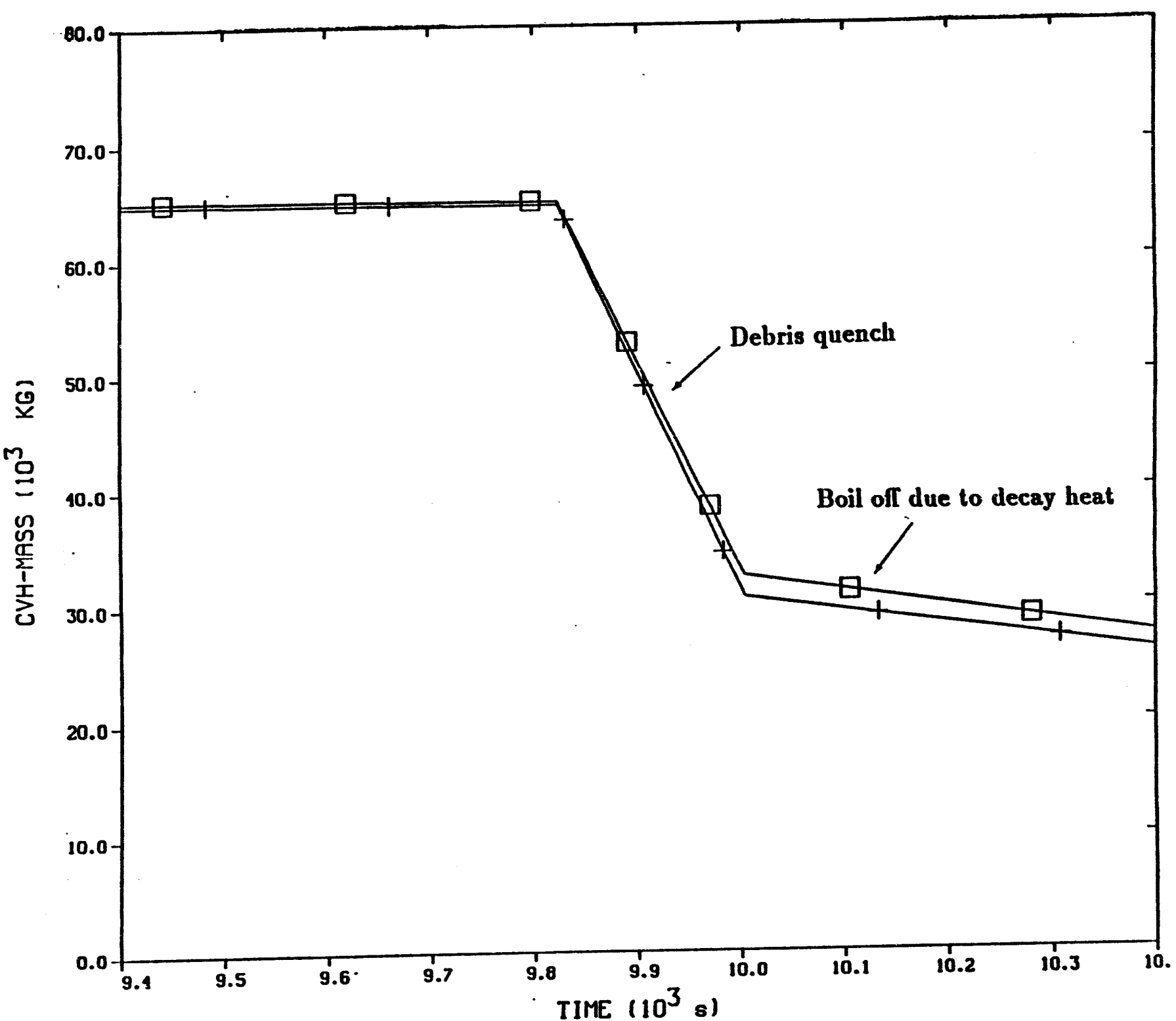

菅 magnifying the debris quench time scale. 


\section{B.3 Effect of Operating System Math Run Time Library Routines on MELCOR Calculations [18]}

Table B.4 presents MELCOR-calculated timing of key events for Peach Bottom Long-Term Station Blackout for $\Delta t_{\text {(max) }}=10,5,3,2$, and 1 sec. These calculations have used the same input decks as in Section B.1. However, the BNL VAX operating system had been upgraded to VMS Version 5.4-1A. Along with the operating system upgrade, a new library of routines for existing math functions was developed. "For previous VMS releases, these math routines were developed for scaler processors since that feature was not then available. This was changed with the new release. It is expected that computer codes that access these routines may experience a change in the results of some calculations that are based on floating point

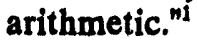

Comparing Table B.4 (new results) with Table B.1 reveals the following:

1. For $\Delta t_{\text {(max) }}=10 \mathrm{~s}$ and 3s, the new results are similar to the earlier results with VAXNMS Version 5.3-1.

2. For $\Delta t_{(\max )}=1 \mathrm{~s}$, the differences are substantial. The lower plenum dryout time is reduced from 11,400 s to 4250 s. Vessel failure occurs about 8000 s sooner and the drywell fails 5000 s sooner than the earlier calculation.

3. For $\Delta t_{(\max )}=5 s$ and $2 s$, the differences are remarkable.

a. For the new $2 \mathrm{~s}$ calculation, the core plate fails first in Ring 1 at $\sim 9200 \mathrm{~s}$, and much later at 19,000 s in Ring 2. The lower plenum dryout time is now about 3900 s. Compare this with the unusual behavior of the earlier $2 \mathrm{~s}$ calculation, when early core plate failure occurred in Ring 2, followed soon by Ring 1, and a very short dryout time of 1230s.

b. This time, the new $5 \mathrm{~s}$ calculation displays the unusual behavior of early core plate failure in Ring 2. In addition, vessel (penetration) failure in Ring 1 at 13,620s leads to early drywell failure only 260 s later, due to increased hydrogen pressure buildup in the containment. Core debris ejection begins much later at $\sim 18,150$ s. The run terminated at 23,459s due to a floating point overflow routine MLTREA, Line 663.

Figures B.6 and B.7 show hydrogen pressure history in the drywell as calculated with the new (VMS V5.4) and earlier (VMS V5.3) operating systems, respectively.

In the newer calculations, the hydrogen pressure is greater by about $30 \mathrm{kPa}$, which is enough to fail the drywell during the first pressure peak after vessel failure as shown in Figure B.8. Figure B.9 shows the earlier calculation in which the first pressure peak did not reach the drywell failure pressure of 9.1 bars.

'P. Kessler, Personal Communication, Brookhaven National Laboratory, March 1991. 
Table B.4 Impact of Maximum Allowable Timestep Size on Predicted Timing of Key Events (MELCOR Version 1.8DNX)*

\begin{tabular}{|c|c|c|c|c|c|}
\hline \multirow[b]{2}{*}{ Key Event } & \multicolumn{5}{|c|}{ Time (sec) } \\
\hline & $\Delta t_{(\max )}=10 \mathrm{~s}$ & $\Delta t_{(\max )}=5 s$ & $\Delta t_{(\max )}=38$ & $\Delta t_{(\operatorname{man})}=2 s$ & $\Delta t_{(\max )}=18$ \\
\hline Core uncovery & 0.0 & 0.0 & 0.0 & 0.0 & 0.0 \\
\hline $\begin{array}{l}\text { Fission product release } \\
\text { from gap in Ring No. } 1\end{array}$ & $4,677.3$ & $4,791.2$ & $4,486.4$ & $4,522.2$ & $4,543.7$ \\
\hline $\begin{array}{l}\text { Fission product release } \\
\text { from gap in Ring No. } 2\end{array}$ & $5,152.2$ & $5,281.6$ & $5,000.6$ & $5,054.1$ & $5,076.6$ \\
\hline $\begin{array}{l}\text { Fission product release } \\
\text { from gap in Ring No. } 3\end{array}$ & $6,876.0$ & $6,981.6$ & $9,308.2$ & $6,902.6$ & $8,938.9$ \\
\hline $\begin{array}{l}\text { Core plate failure in Ring } \\
\text { No. } 1\end{array}$ & $9,822.6 .6$ & $11,247.5$ & $10,649.2$ & $9,177.8$ & $10,060.8$ \\
\hline Lower plenum dryout & $17,268.7^{\circ}$ & $11,605.3$ & $16,951.2$ & $13,066,4$ & $14,313.8$ \\
\hline $\begin{array}{l}\text { Vessel failure } \\
\text { (penetration Ring No 1) }\end{array}$ & $20,448.9$ & $13,620.3$ & $19,297.2$ & $15,304.4$ & $15,518.8$ \\
\hline $\begin{array}{l}\text { Reactor vessel } \\
\text { depressurized }\end{array}$ & $20,508.0$ & $13,684.7$ & $19,348.2$ & $15,372.4$ & $15,583.8$ \\
\hline $\begin{array}{l}\text { Core plate failure in Ring } \\
\text { No. } 2\end{array}$ & $23,330.6$ & 99014.9 & $23,521.3$ & $19,013.5$ & $21,565.8$ \\
\hline $\begin{array}{l}\text { Beginning of debris } \\
\text { ejection to cavity }\end{array}$ & $25,250.6$ & $18,149.4$ & $24,160.3$ & $19,861.5$ & $20,193.8$ \\
\hline $\begin{array}{l}\text { Core plate failure in Ring } \\
\text { No. } 3\end{array}$ & $26,080.6$ & & $25,897.3$ & $21,383.5$ & $24,831.8$ \\
\hline $\begin{array}{l}\text { Lower head penetration } \\
\text { fails in Ring No. } 2\end{array}$ & $24,590.6$ & $14,797.2$ & $29,332.9$ & $22,895.7$ & $25,410.6$ \\
\hline Drywell failure & $28,661.2$ & $13,884.7$ & $29,239.3$ & $22,637.5$ & $25,067.7$ \\
\hline $\begin{array}{l}\text { Deflagrations start in } \\
\text { Reactor Building }\end{array}$ & $28,674.2$ & $13,893.8$ & $29,244.5$ & $22,642.3$ & $25,071.4$ \\
\hline $\begin{array}{l}\text { Deflagrations end in } \\
\text { Reactor Building }\end{array}$ & $28,728.8$ & $13,945.7$ & $29,300.9$ & $22,701.0$ & $25,129.5$ \\
\hline $\begin{array}{l}\text { Lower head penetration } \\
\text { fails in Ring No. } 3\end{array}$ & $29,126.1$ & & $29,423.6$ & $23,235.7$ & $25,688.6$ \\
\hline $\begin{array}{l}\text { Deflagrations start in } \\
\text { Reactor Building }\end{array}$ & $47,713.6$ & & $50,388.5$ & & $46,085.3$ \\
\hline $\begin{array}{l}\text { Deflagrations end in } \\
\text { Reactor Building }\end{array}$ & $49,803.2$ & & $52,316.3$ & & $50,905.6$ \\
\hline $\begin{array}{l}\text { Fission product release } \\
\text { ends }\end{array}$ & $31,859.4$ & & & $24,457.7$ & $52,981.6$ \\
\hline
\end{tabular}


Appendix B

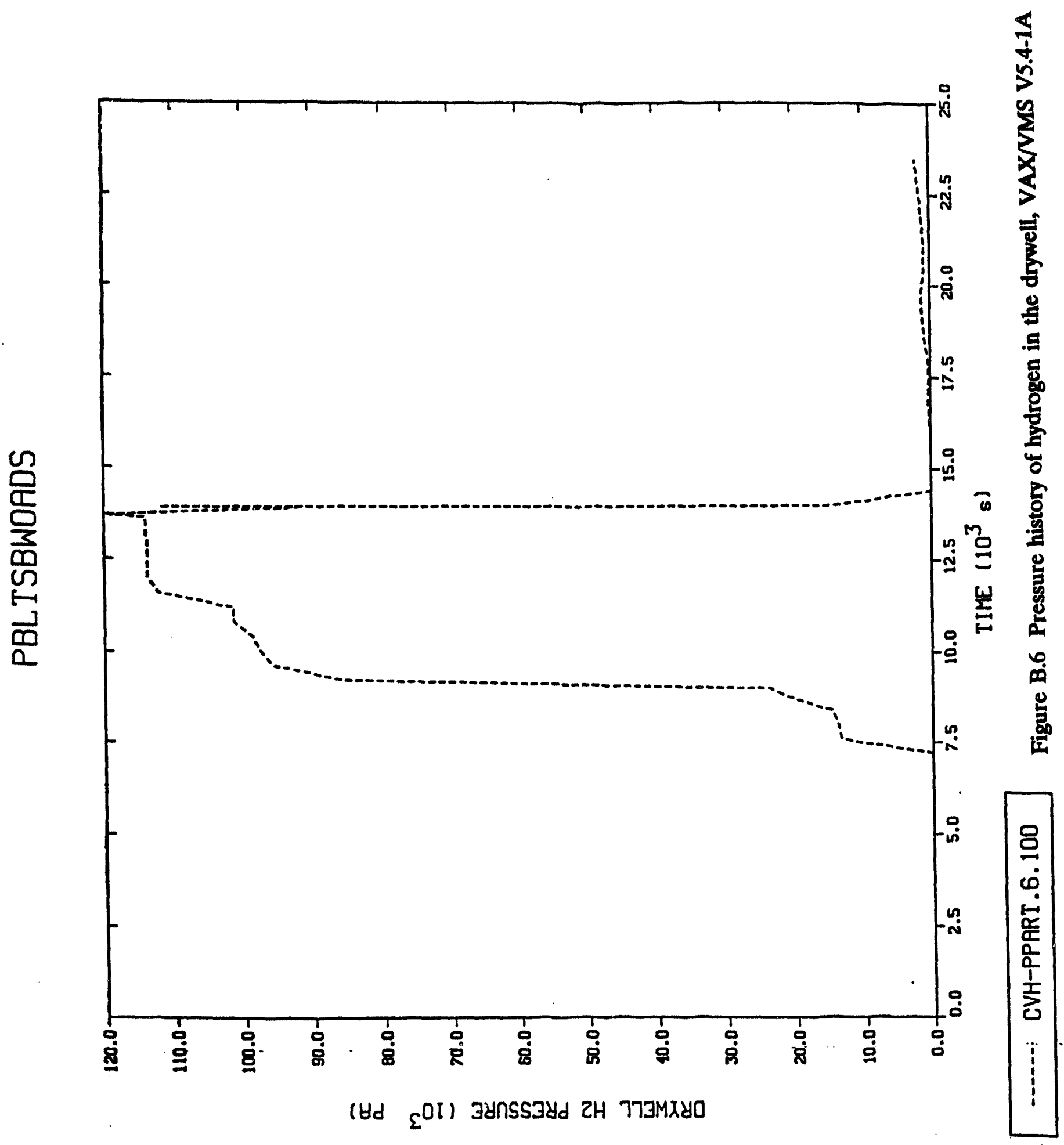


Appendix B

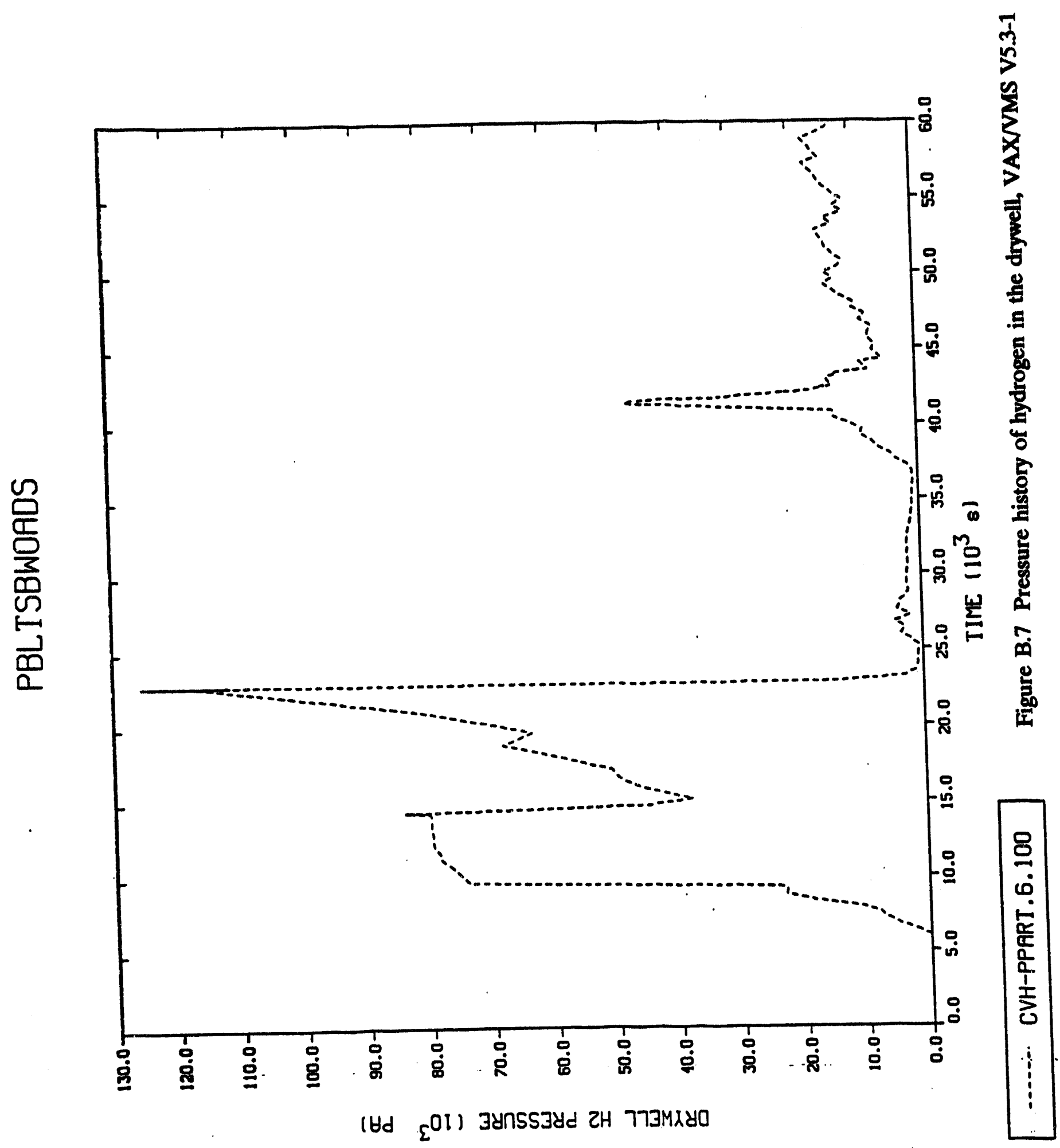




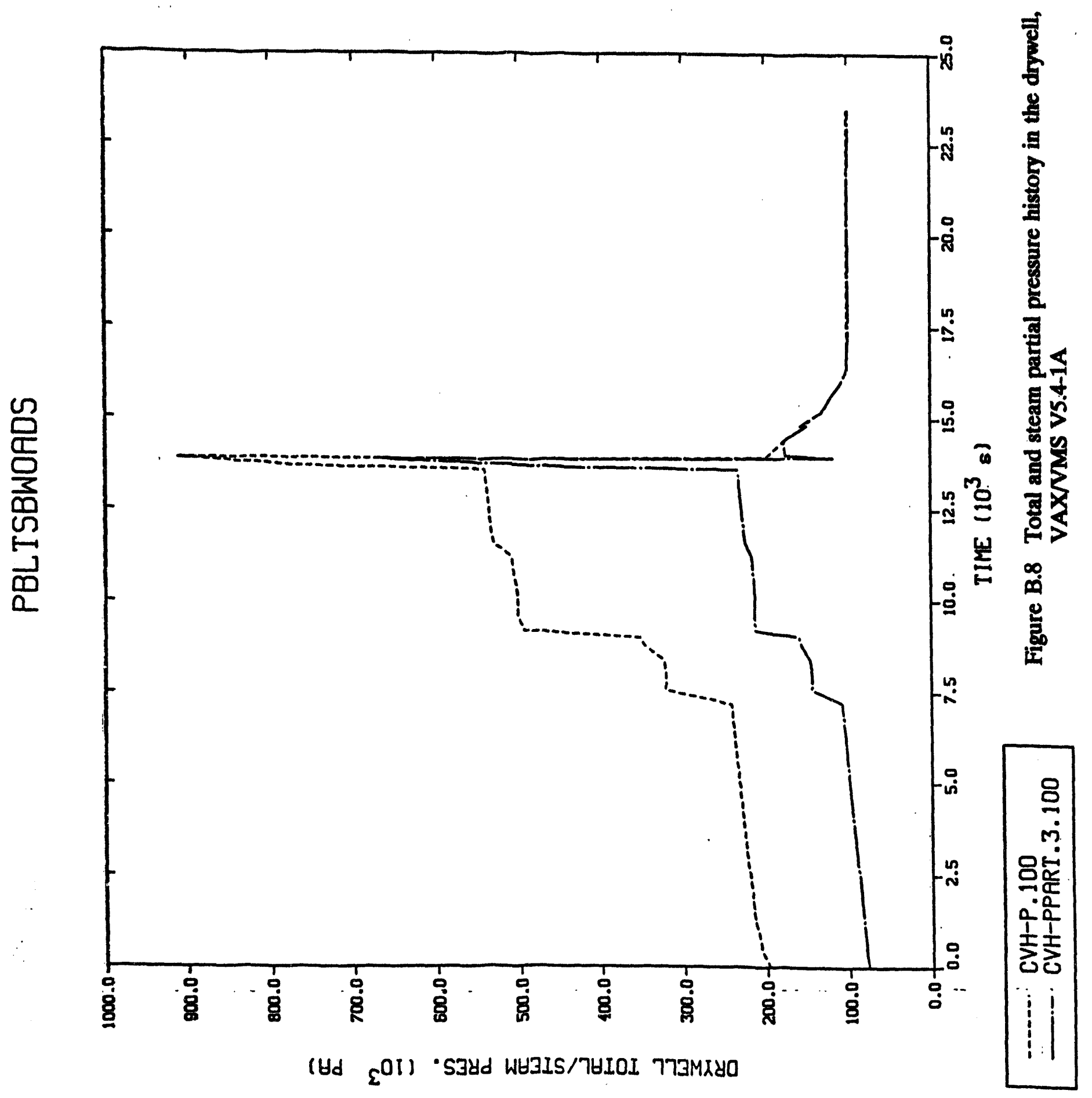


Appendix B

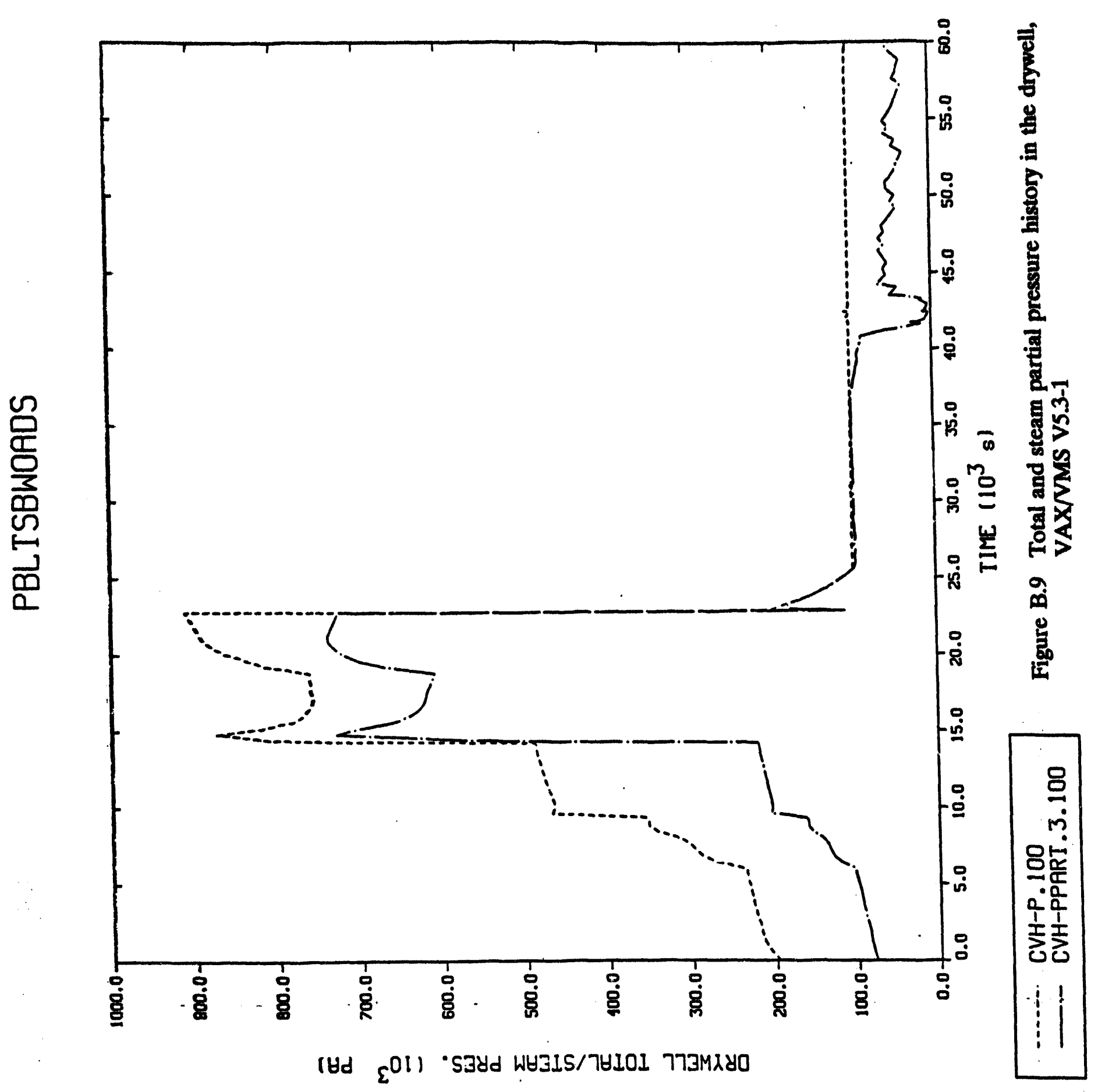




\section{Appendix C}

\section{Additional Calculations and Findings from MELCOR 1.8.2}

\section{C.1 Impact of Maximum Allowable Timestep $\left(\Delta \mathrm{t}_{\max }\right)$ on Peach Bottom Station Blackout Calculations Using MELCOR 1.8.2}

Long-term station blackout analyses in Peach Bottom were first carried out using MELCOR 1.8BC, as part of an overall program between the U.S. Nuclear Regulatory Commission (NRC) and Brookhaven National Laboratory (BNL), to provide independent assessment of MELCOR as a severe accident/source term analysis tool. In addition to the reference MELCOR calculation, several sensitivity calculations were also performed to explore the impact of varying user-input modeling and timestep control parameters on the accident progression and radionuclide releases to the environment calculated by MELCOR. The sensitivity studies helped to assess MELCOR by evaluating the changes in results in response to changes in input parameters.

An area of concern that emerged from these studies was the impact of the selection of maximum allowable timestep $\left(\Delta t_{\text {max }}\right)$ on the calculational behavior of MELCOR. Complete sequence calculations were carried out selecting two variations of $\Delta t_{\max }(5$ and $3 \mathrm{sec}$ ), in addition to the reference case using $\Delta t_{\max }=10$ sec. Both variations were seen to delay the occurrence of most key events compared to the reference calculation and to substantially increase the release of Cs and I to the environment. The $5 \mathrm{sec}$ case gave the largest deviation in timing. With the release of a newer version of the code, $1.8 \mathrm{DN}$, the impact of $\Delta t_{\max }$ was re-examined using MELCOR 1.8DNX (1.8DN with corrections for two code errors). Complete sequence calculations were carried out (see Appendix B) selecting five variations of $\Delta t_{\max }(10,5,3,2$, and $1 \mathrm{sec})$. Once again, the results showed significant differences in timing of key events, and a lack of convergence of the solution with reduction of $\Delta t_{\max }$. The maximum uncertainty in environmental release fractions was a factor of seven (for $R u$ ) and within a factor of four for the rest of the radionuclides over the entire range of $\Delta t_{\max }$.

These findings were reported to the NRC, SNL, and the MELCOR Peer Review Committee. This alerted the NRC, the code developers, and the MELCOR Peer Reviewers to the importance of correcting the numerical sensitivities. As a consequence, a significant effort was undertaken to eliminate or mitigate these sensitivities. The latest released version of MELCOR, Version 1.8.2, released in April 1993, contains several new or improved models, and has corrections to mitigate numerical sensitivities [21].

The purpose of this Appendix is to update the Appendix B sensitivity studies on maximum timestep, to more properly represent the abilities of the improved MELCOR version 1.8.2.

Note that the Peach Bottom input deck has evolved since the last study with MELCOR $1.8 \mathrm{DNX}$, mainly in response to code changes and improvements, but also with the inclusion of a radiation option for in-vessel heat structures. The current deck has most of the new models available in MELCOR 1.8.2 activated, such as eutectic interactions, in-vessel radial relocation of debris, in-vessel falling debris quench model, and boundary fluid temperature option. 

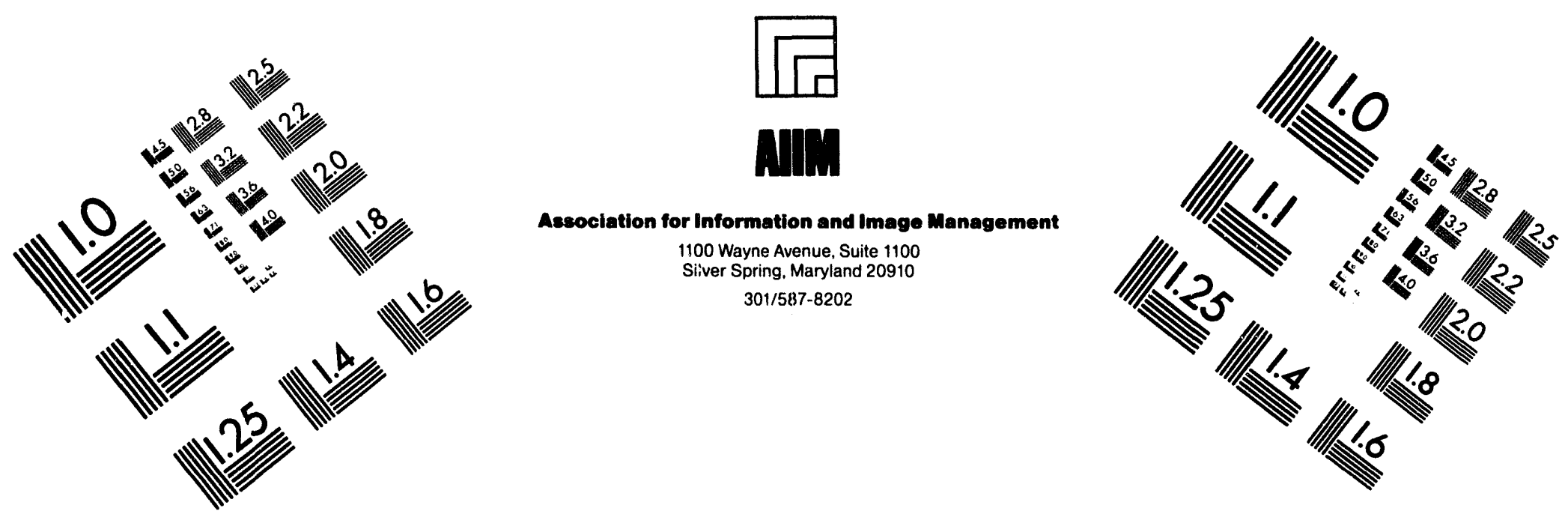

\section{Centimeter}

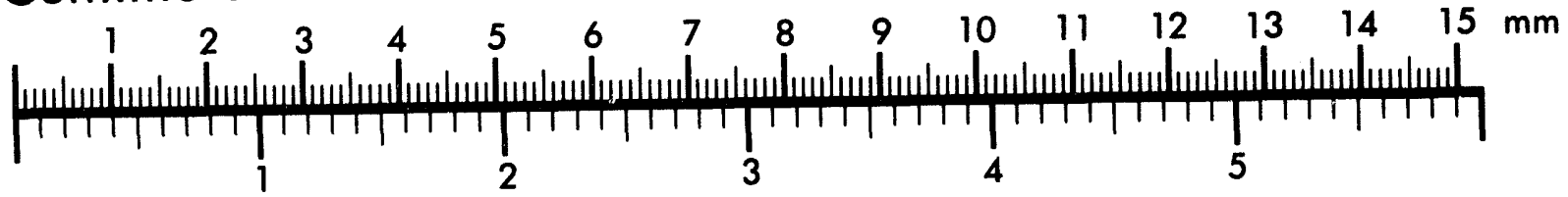

Inches
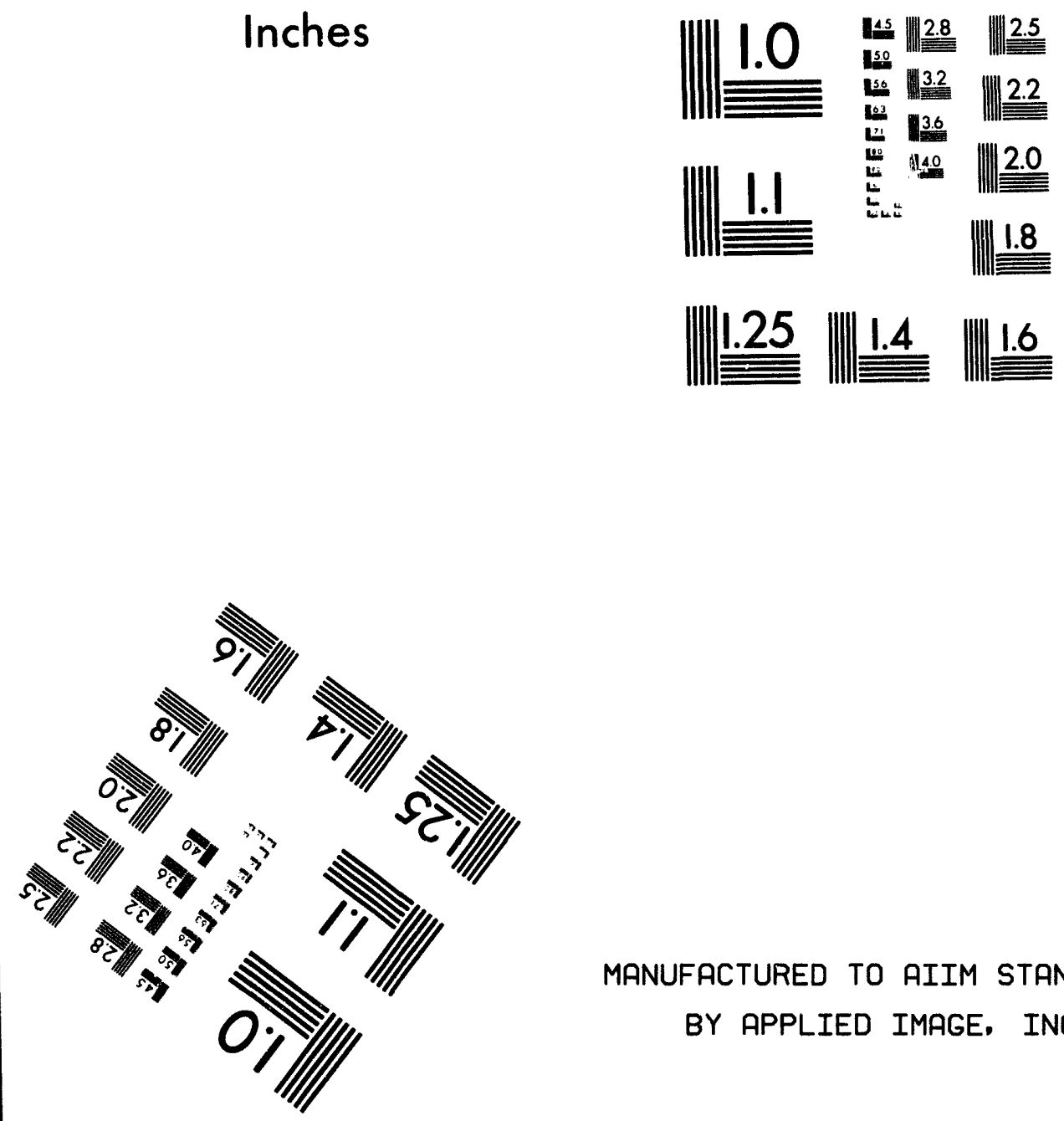

MANUFACTURED TO AIIM STANDARDS

BY APPLIED IMAGE, INC.

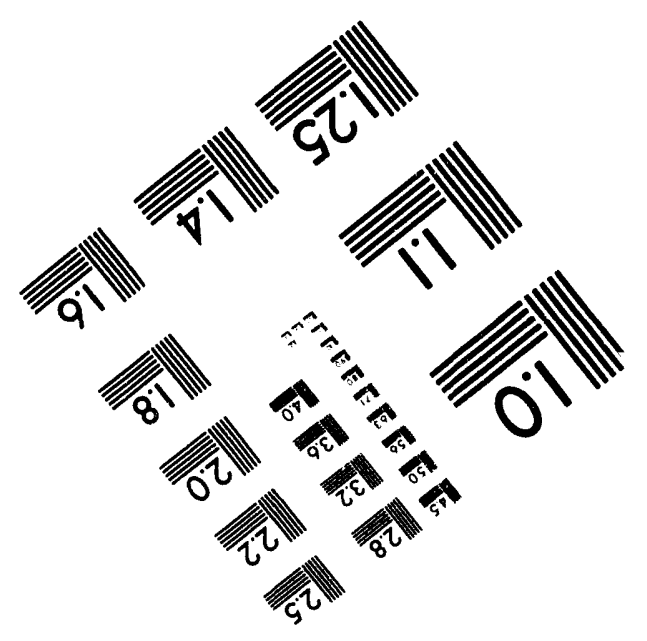



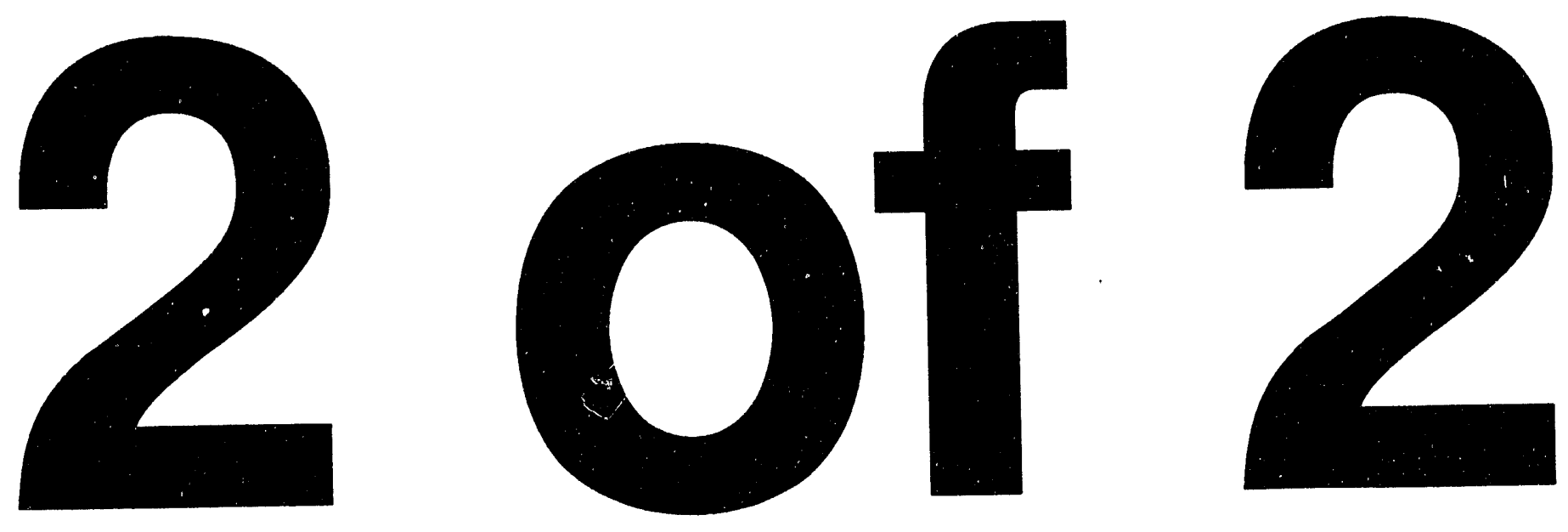
The current Peach Bottom input model has been used in rerunning the sensitivity studies to $\Delta t_{\max }$ with MELCOR 1.8.2, since this deck properly reflects the new features available in the latest released code version.

Complete sequence calculations were carried out using MELCOR 1.8.2 and the current Peach Bottom input deck, once again selecting five variations of $\Delta t_{\max }(10,5,3,2$, and $1 \mathrm{sec})$.

Table C.1 presents MELCOR-calculated timing of key events. While there is no convergence of the solution in going to a smaller $\Delta t_{\max }$ there is clearly very close agreement in the timing of key events, from gap releases of fission products, to core collapse, lower plenum dryout, vessel failure, drywell failure, onset of deflagrations in the reactor building, and debris ejection to the cavity. In most cases, the deviations in timing are limited to a few hundred seconds. Earlier calculations using MELCOR 1.8DNX showed much larger deviations, many as high as 10,000 seconds. This is certainly evidence of improved numerical behavior of MELCOR 1.8.2.

A few points worth noting are listed below.

1. All calculations reported in this section were performed on the VAX 6450 mainframe computer, with VAX/VMS version 5.5-2 operating system. Earlier calculations using MELCOR 1.8DNX were also performed on the VAX mainframe.

2. All calculations shown here result in early drywell failure. In comparison, earlier calculations with MELCOR 1.8DNX resulted in delayed drywell failure.

3. While reducing $\Delta t_{\max }$ does not lead to a converged solution, this is to be expected, since full-plant simulations involve many branch points in the calculational logic, and many threshold and competing phenomena. There is evidence that there is still some residual sensitivity due to these threshold phenomena. For instance, the $\Delta t_{\max }=10$ sec case shown in Table C.1 was initiated with $\Delta t_{\max }=2 \mathrm{sec}$, before switching to $\Delta t_{\max }$ $=10 \mathrm{sec}$ at $1000 \mathrm{sec}$. Starting the calculation with $\Delta \mathrm{t}_{\max }=10 \mathrm{sec}$ from $\mathrm{t}=0.0 \mathrm{sec}$ (which caused the calculation to fail at $20,000 \mathrm{sec}$ due to excessive $\Delta t$ reductions) resulted in a delayed drywell failure time of $18,000 \mathrm{sec}$. This is because, whereas in the case reported in Table C.1, the initial pressure spike in the drywell following vessel failure was sufficient to fail the drywell, in the other case, the initial pressure spike came close to but couldn't reach the drywell failure threshold.

4. The calculations using $\Delta \mathrm{t}_{\max }=10 \mathrm{sec}, 5 \mathrm{sec}$, and $2 \mathrm{sec}$ all failed due to excessive $\Delta t$ reductions. After consulting with SNL, these errors were circumvented by recalculating from the last previous restart, with a different $\Delta t_{\max }$ for a small portion of the transient.

5. Activation of the new radial debris relocation models in MELCOR 1.8.2, causes vessel (penetration) failures in all 3 radial rings to occur much closer together. Earlier calculations using MELCOR 1.8DNX showed staggering of penetration failures in different rings by as much as $13,000 \mathrm{sec}$.

Figures C.1-C.17 visually illustrate the impact of $\Delta \mathrm{t}_{\max }$ on various thermal-hydraulic phenomena in the vessel and containment. The results for most parameters show close agreement over the entire range of $\Delta t_{\max }$ from $1 \mathrm{sec}$ to $10 \mathrm{sec}$. Where there are some deviations observed, such as in temperature of atmosphere in the core and upper plenum, RPV dryer temperature (maximum 
deviation of $14 \%$ ), total hydrogen production in the core (maximum deviation of $17 \%$ ), radioactive mass deposited on the separators (maximum deviation $=50 \%$ ), the trends are very similar.

The figures also show very clearly that there is no convergence with reduction of $\Delta \mathrm{t}_{\max }$. For example, the upper and lower limits of hydrogen production correspond to $\Delta t_{\max }=10 \mathrm{sec}$ and $5 \mathrm{sec}$, respectively. Likewise, the upper and lower limits of RPV dryer temperature correspond to $\Delta \mathrm{t}_{\max }=$ $3 \mathrm{sec}$ and $2 \mathrm{sec}$, with other $\Delta \mathrm{t}_{\max }$ values in between.

Table C.2 presents MELCOR-calculated environmental releases of radionuclides. Again, while there is no convergence of the solution for smaller values of $\Delta t_{\max }$ the maximum deviation in release fractions is a factor of 2 , while the deviation for most of the radionuclides is much less than that. This is again a dramatic improvement over the earlier results using MELCOR 1.8DNX.

Table C.1 Impact of Maximum Allowable Timestep Size on Predicted Timing of Key Events (MELCOR Version 1.8.2)

\begin{tabular}{|c|c|c|c|c|c|c|}
\hline \multirow{2}{*}{\multicolumn{2}{|c|}{ Key Event }} & \multicolumn{5}{|c|}{ Time (sec) } \\
\hline & & $\Delta c_{\operatorname{mam}}=10 \mathrm{~s}$ & $\Delta t_{m}=5 \mathrm{~s}$ & $\Delta t_{m}=3 s$ & $\Delta L_{m}=2 s$ & $\Delta t_{m}=1 s$ \\
\hline \multirow{3}{*}{ Gap Release of Fission Products } & Ring 1 & 4668.2 & 4601.4 & 4561.5 & 4527.1 & 4479.1 \\
\hline & Ring 2 & 5116.7 & 5041.4 & 5029.5 & 5007.1 & 4971.1 \\
\hline & Ring 3 & 8526.0 & 8642.1 & 8025.1 & 8378.9 & 8665.7 \\
\hline \multirow{3}{*}{ Core Collapse } & Ring 1 & $11,713.7$ & $11,537.9$ & $11,668.8$ & $11,090.1$ & $12,612.7$ \\
\hline & Ring 2 & $11,726.5$ & $11,552.7$ & $11,684.2$ & $11,117.5$ & $12,635.0$ \\
\hline & Ring 3 & $12,533.9$ & $13,685.9$ & $12,055.1$ & $12,415.4$ & $13,406.4$ \\
\hline \multicolumn{2}{|l|}{ Lower Plemum Dryout } & $11,765.5$ & $11,593.7$ & $11,716.3$ & $11,132.0$ & $12,654.5$ \\
\hline \multirow{3}{*}{ Vessel (Penetration) Failure } & Ring 1 & $12,244.5$ & $13,260.9$ & $13,128.6$ & $11,927.4$ & $12,778.4$ \\
\hline & Ring 2 & 11785.9 & $11,657.4$ & $11,758.5$ & $11,321.0$ & $12,704.0$ \\
\hline & Ring 3 & $11,785.9$ & $11,610.3$ & $11,755.5$ & $11,185.7$ & $12,676.7$ \\
\hline \multicolumn{2}{|l|}{ Reactor Vessel Deprossurized } & $11,894.5$ & $11,727.1$ & $11,857.9$ & $11,286.2$ & $12,787.7$ \\
\hline \multicolumn{2}{|l|}{ Drywell Failure (Overpressure) } & $11,953.9$ & $11,925.3$ & $11,980.5$ & $11,666.2$ & $12,944.7$ \\
\hline \multicolumn{2}{|c|}{ Dellagrations Begin in Reactor Building } & $11,960.8$ & $11,938.3$ & $11,986.7$ & $11,676.0$ & $12,949.3$ \\
\hline \multicolumn{2}{|l|}{ Debris Ejection to Cavity Begins } & $15,352.8$ & $15,900.9$ & $16,032.6$ & $14,929.4$ & $15,830.4$ \\
\hline \multicolumn{2}{|l|}{ End Calculation } & $60,000.0$ & $60,000.0$ & $60,000.0$ & $60,000.0$ & $60,000.0$ \\
\hline
\end{tabular}


Table C.2 Impact of Maximum Allowable Timestep Size on Predicted Environmental Releases of Radionuclides (MELCOR Version 1.8.2)

\begin{tabular}{|c|c|c|c|c|c|}
\hline \multirow{2}{*}{ Class } & \multicolumn{5}{|c|}{ Environmental Release (Fraction) } \\
\hline & $\Delta t_{\min }=10 \mathrm{~s}$ & $\Delta t_{\text {mas }}=5 \mathrm{~s}$ & $\Delta t_{\ldots}=3 \mathrm{~s}$ & $\Delta t_{m_{x}}=2 s$ & $\Delta t_{m=1 s}$ \\
\hline $\mathbf{X e}$ & 0.995 & 0.994 & 0.993 & 0.998 & 0.995 \\
\hline Cs & 0.386 & 0.411 & 0.384 & 0.364 & 0.359 \\
\hline Ba & 0.107 & 0.125 & $0.996 \mathrm{E}-01$ & 0.126 & 0.117 \\
\hline Te & 0.143 & 0.145 & 0.114 & 0.117 & 0.114 \\
\hline $\mathbf{R u}$ & $0.404 \mathrm{E}-03$ & $0.202 \mathrm{E}-03$ & $0.310 \mathrm{E}-03$ & $0.314 \mathrm{E}-03$ & $0.481 \mathrm{E}-03$ \\
\hline Mo & $0.890 \mathrm{E}-02$ & $0.801 E-02$ & $0.813 E-02$ & $0.894 \mathrm{E}-02$ & $0.976 \mathrm{E}-02$ \\
\hline Ce & $0.122 \mathrm{E}-04$ & $0.829 \mathrm{E}-05$ & $0.105 E-04$ & $0.105 E-04$ & $0.141 E-04$ \\
\hline La & $0.144 \mathrm{E}-02$ & $0.273 E-02$ & $0.185 E-02$ & $0.212 \mathrm{E}-02$ & $0.161 \mathrm{E}-02$ \\
\hline $\mathbf{U}$ & $0.449 \mathrm{E}-04$ & $0.233 E-04$ & $0.285 E-04$ & $0.331 E-04$ & $0.382 E-04$ \\
\hline Cd & $0.961 E-02$ & $0.719 \mathrm{E}-02$ & $0.755 E-02$ & $0.882 \mathrm{E}-02$ & $0.107 \mathrm{E}-01$ \\
\hline $\mathbf{S n}$ & $0.119 E-01$ & $0.104 \mathrm{E}-01$ & $0.940 \mathrm{E}-02$ & $0.123 E-01$ & $0.132 E-01$ \\
\hline $\mathbf{B}$ & 0.0 & 0.0 & 0.0 & 0.0 & 0.0 \\
\hline $\mathbf{H}_{2} \mathbf{O}$ & 0.0 & 0.0 & 0.0 & 0.0 & 0.0 \\
\hline Concrete & 0.0 & 0.0 & 0.0 & 0.0 & 0.0 \\
\hline CsI & 0.389 & 0.403 & 0.394 & 0.424 & 0.405 \\
\hline
\end{tabular}


PB DT SENSITIVITY

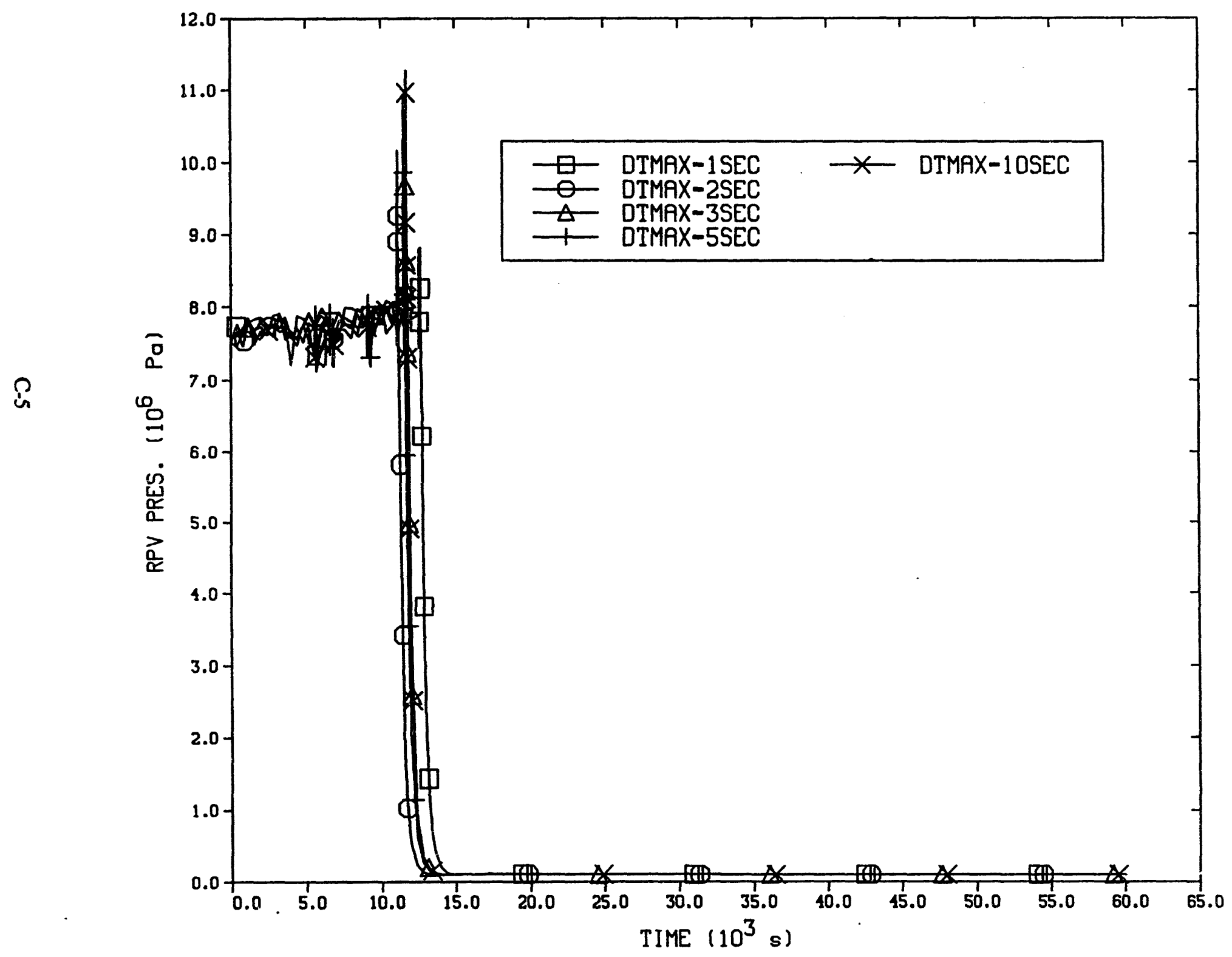




\section{PB DT SENSITIVITY}

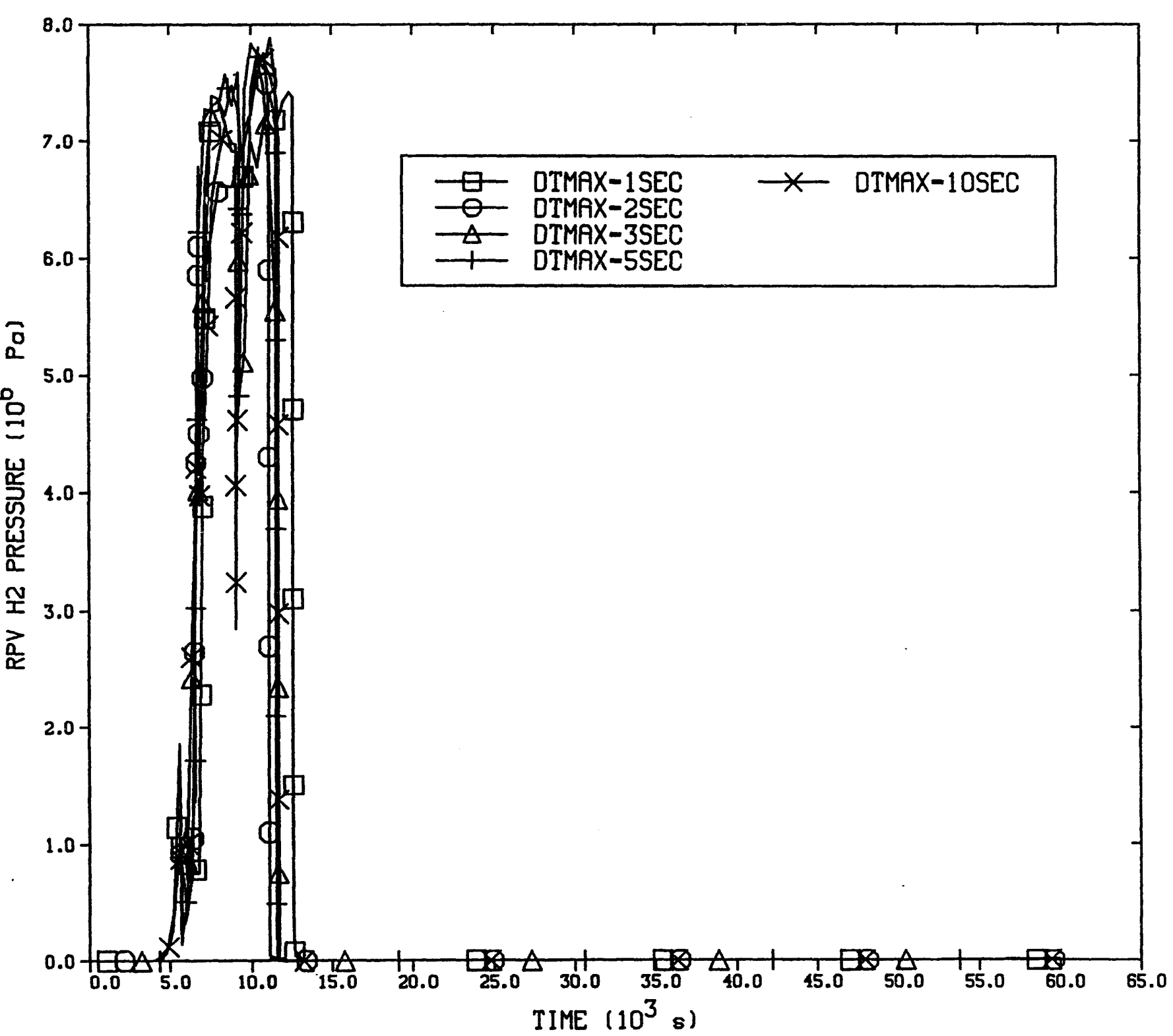


PB DT SENSITIVITY

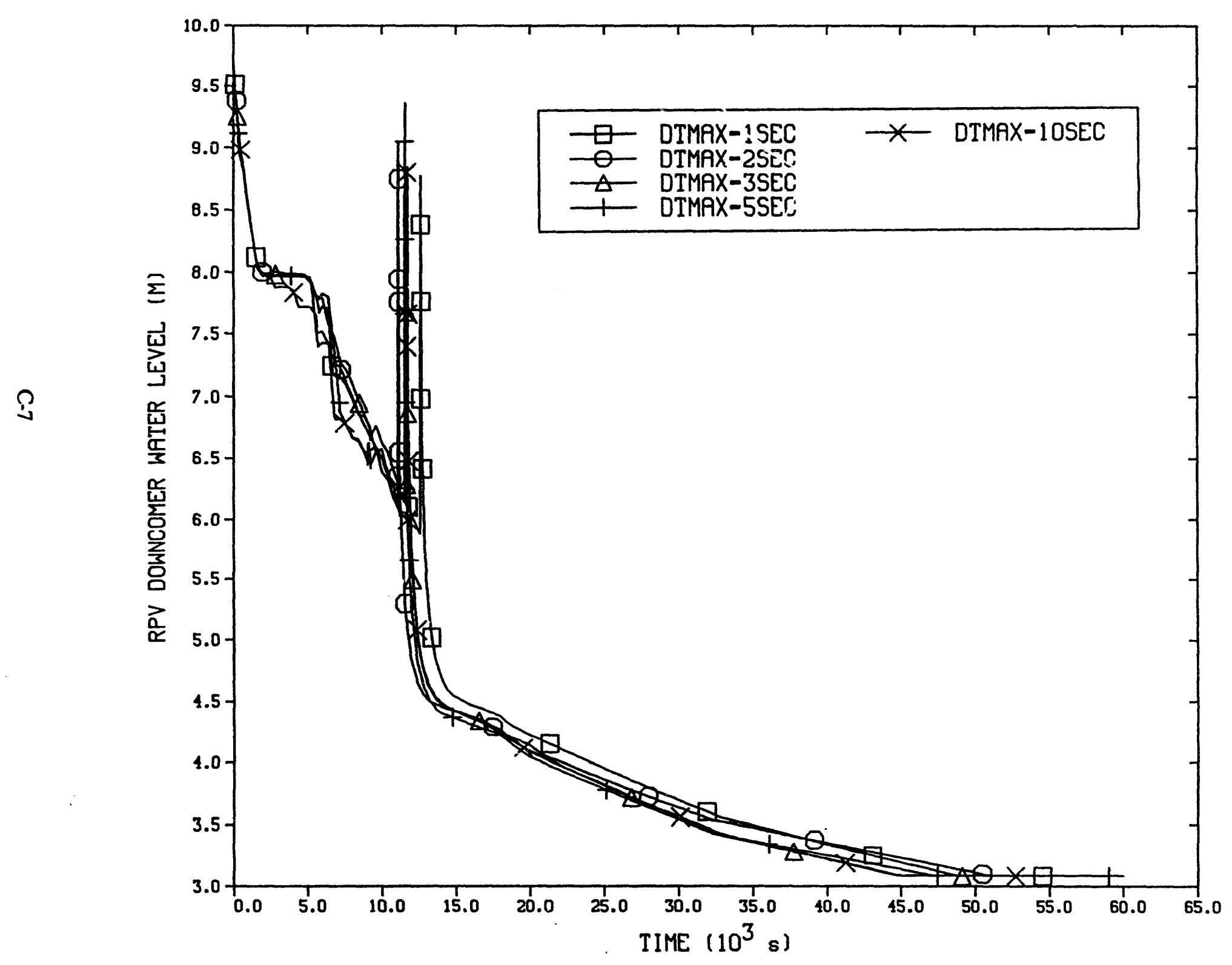


PB DT SENSITIVITY

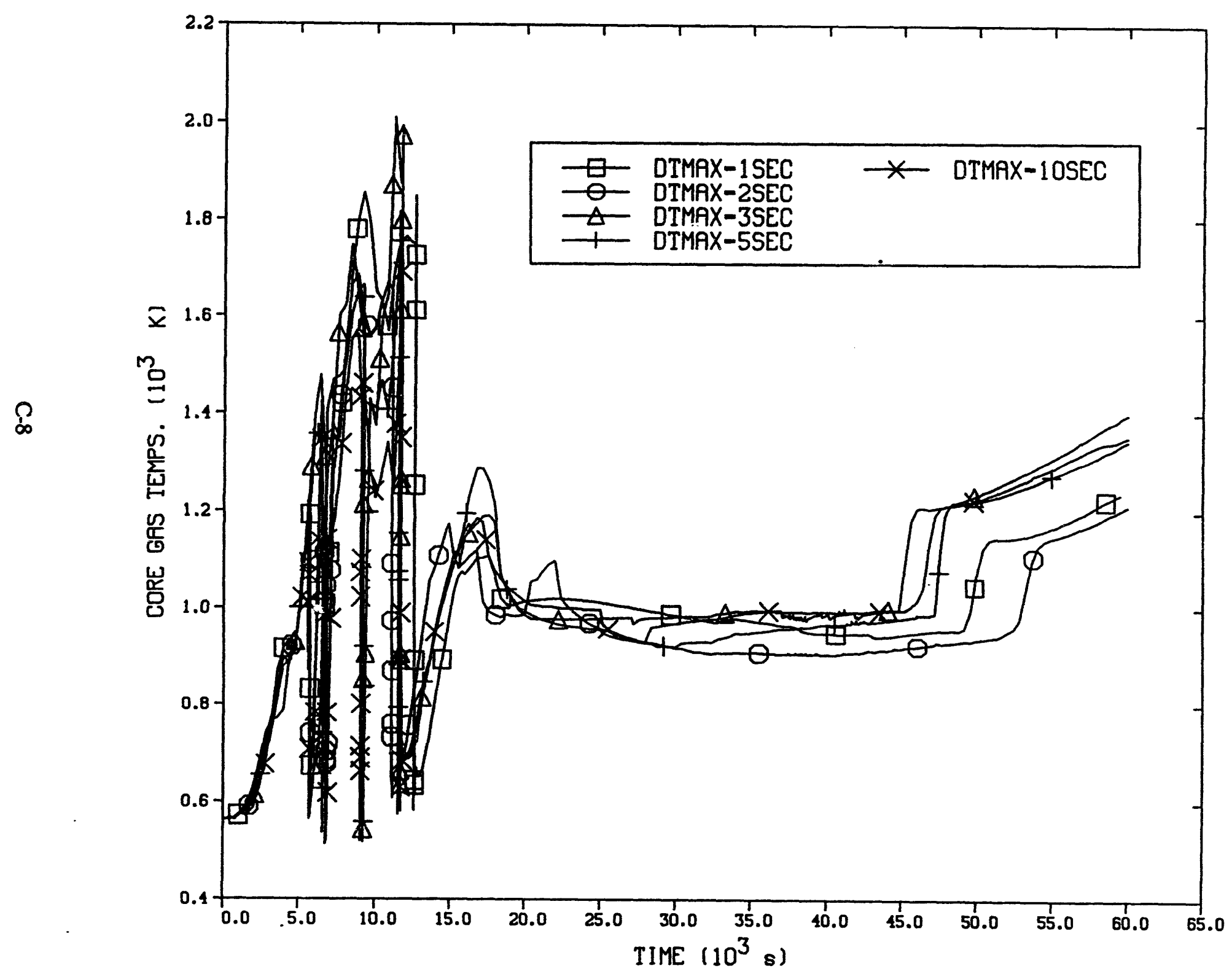




\section{PB DT SENSITIVITY}

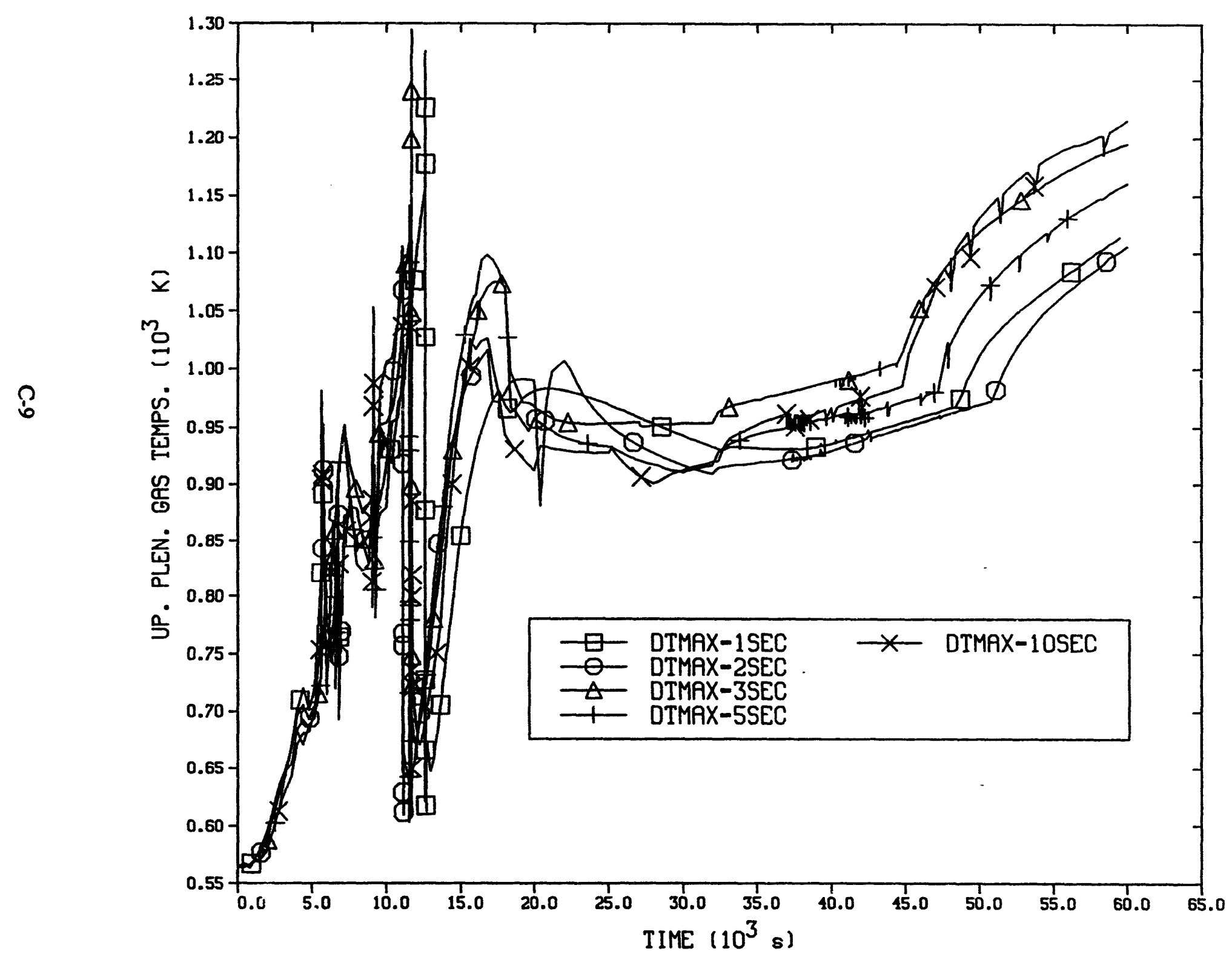




\section{PB DT SENSITIVITY}

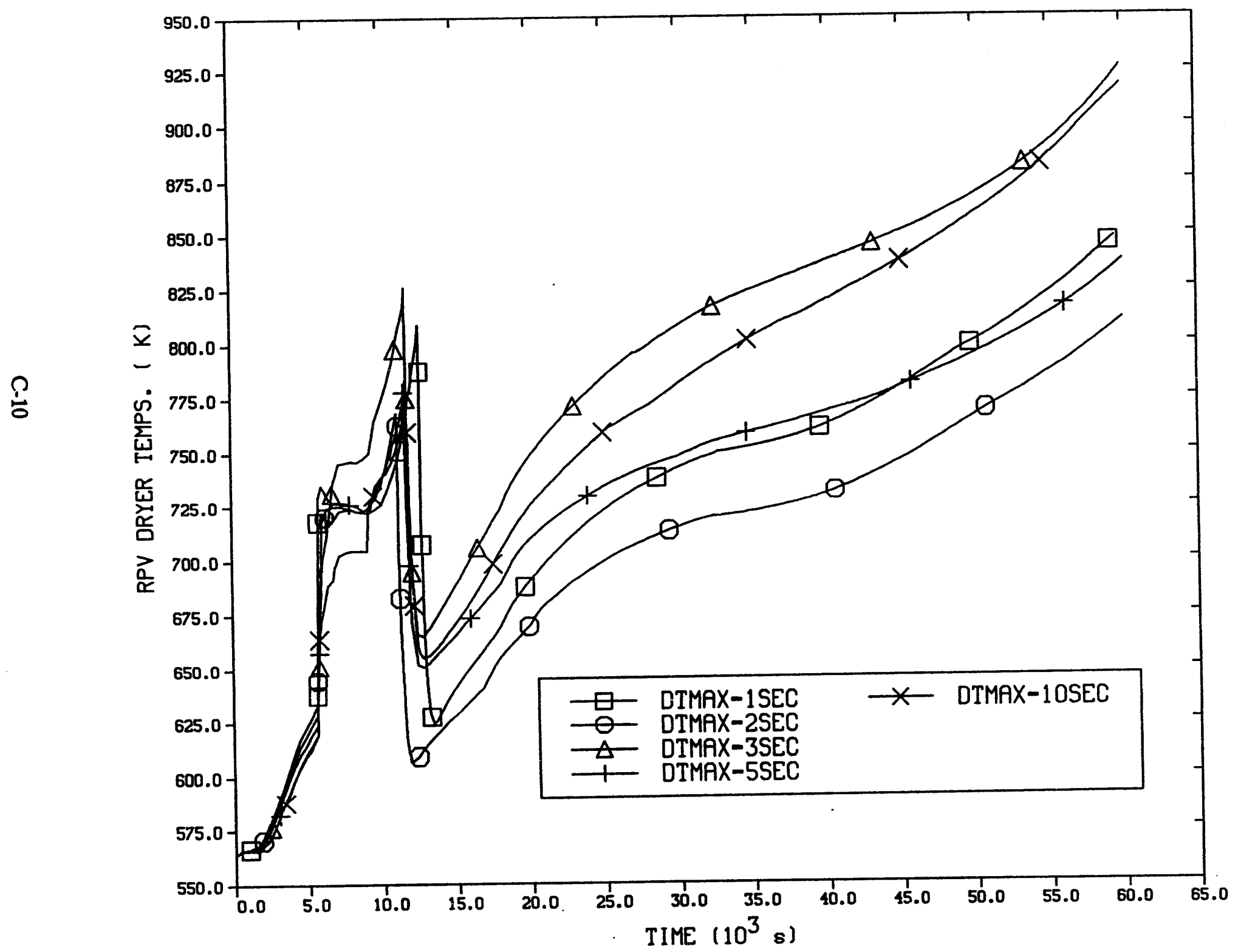


PB DT SENSITIVITY

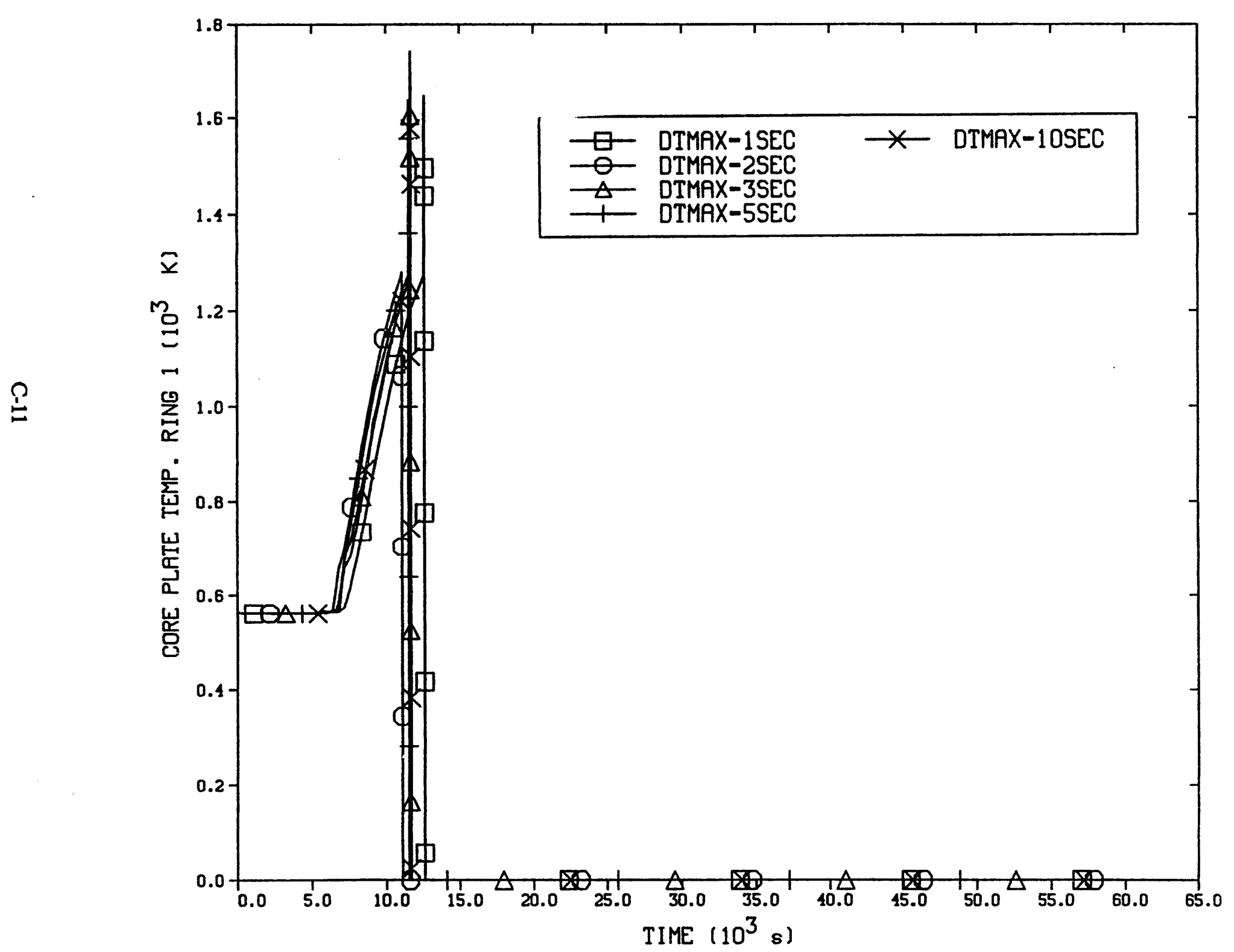


PB DT SENSITIVITY

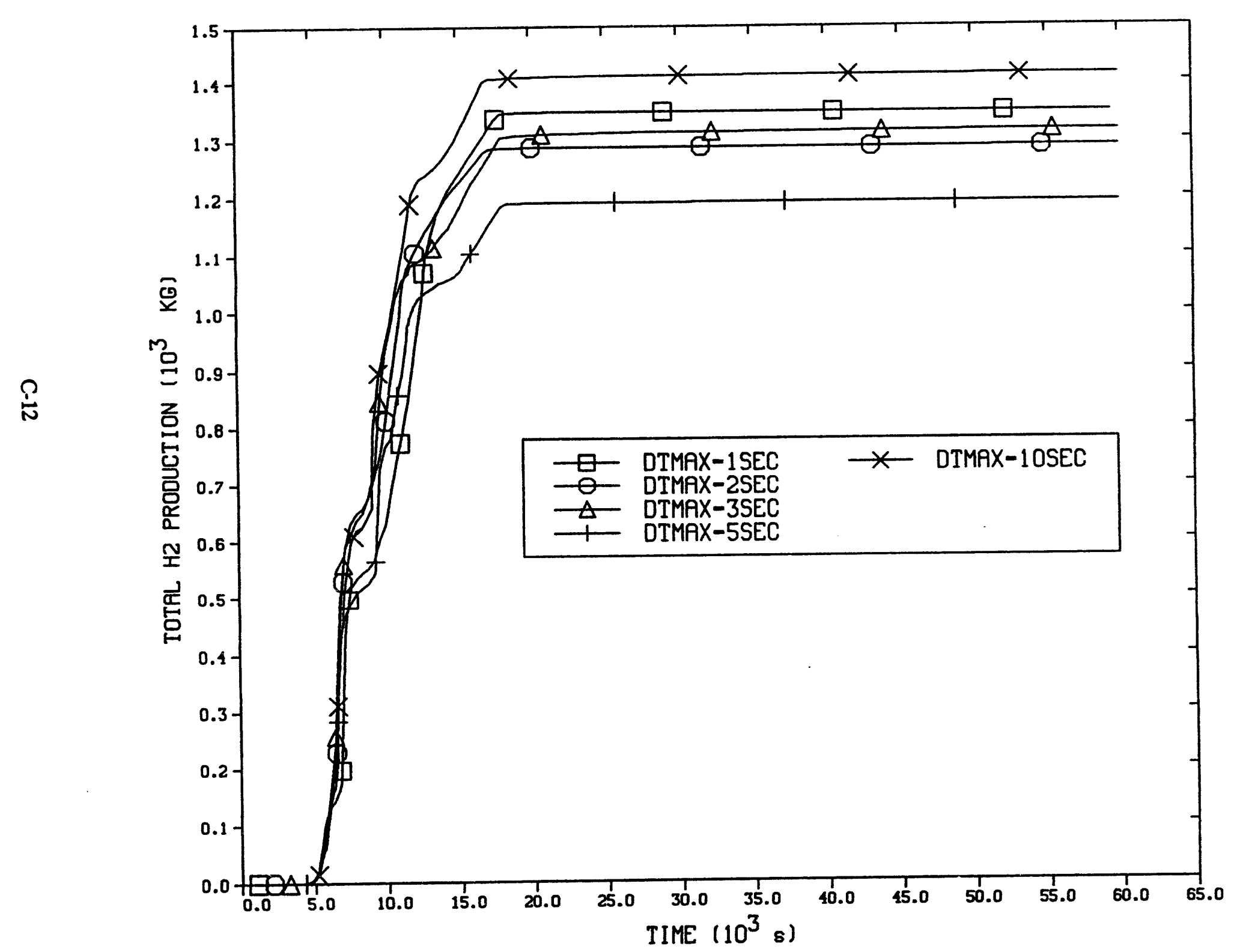


PB DT SENSITIVITY

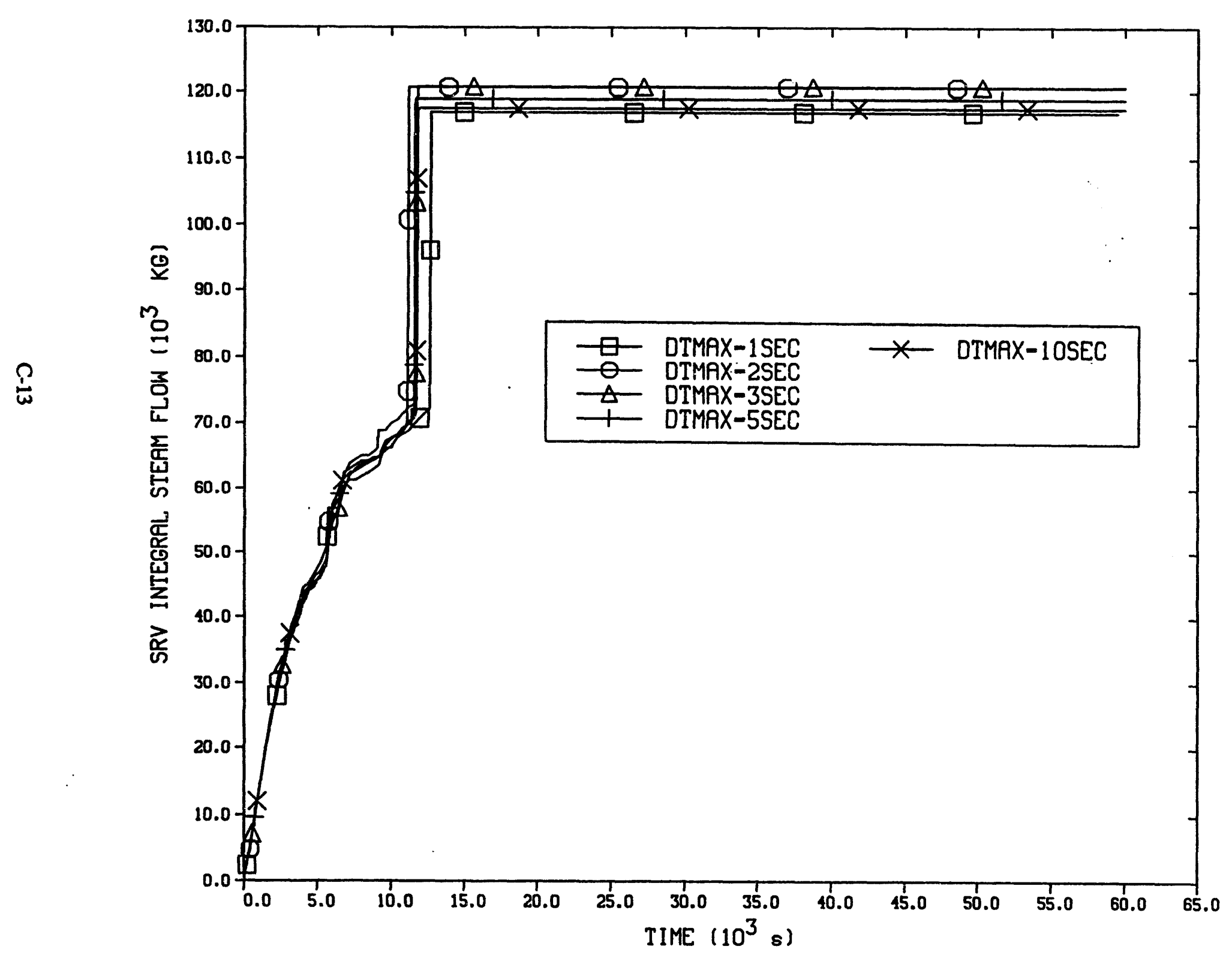




\section{PB DT SENSITIVITY}

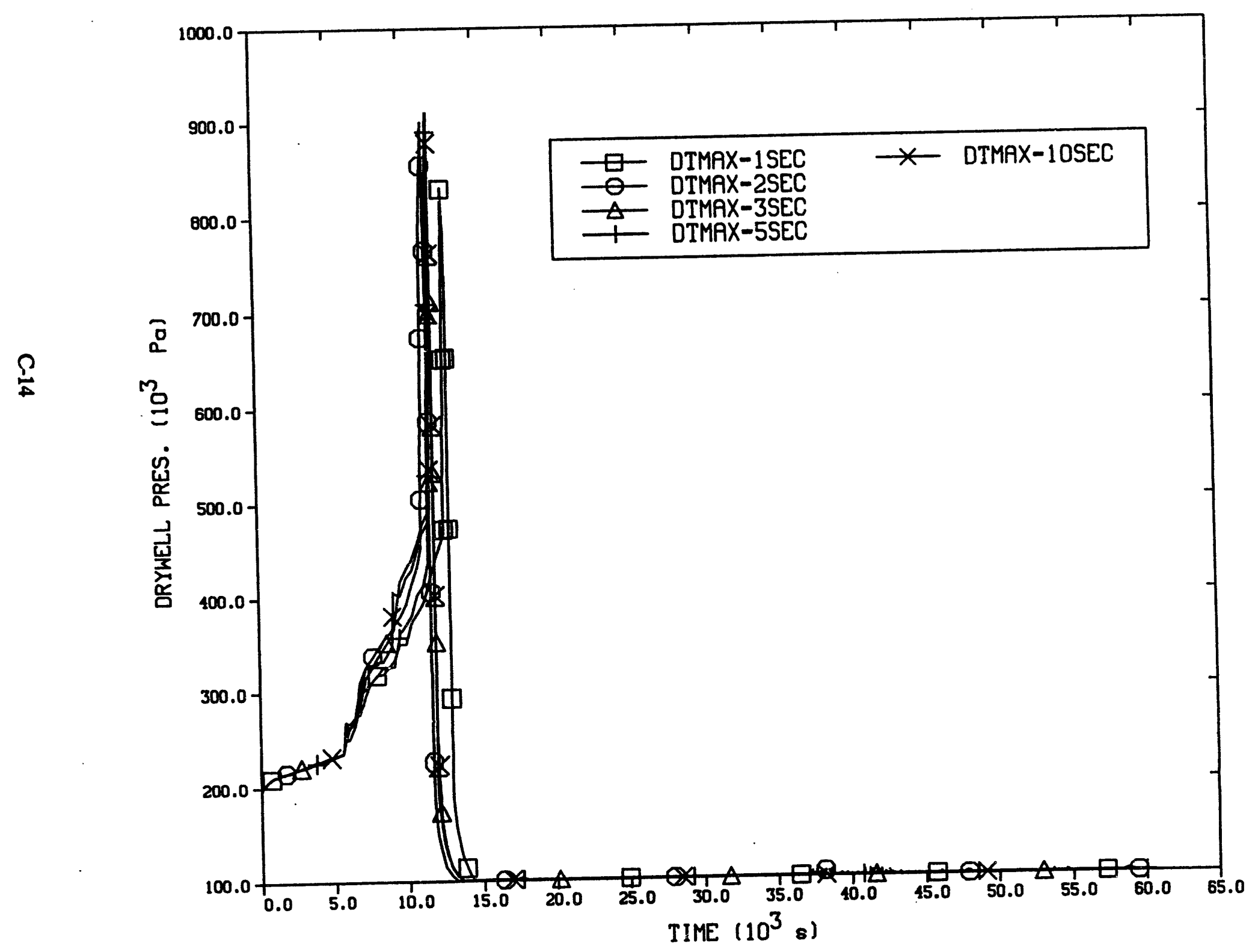


PB DT SENSITIVITY

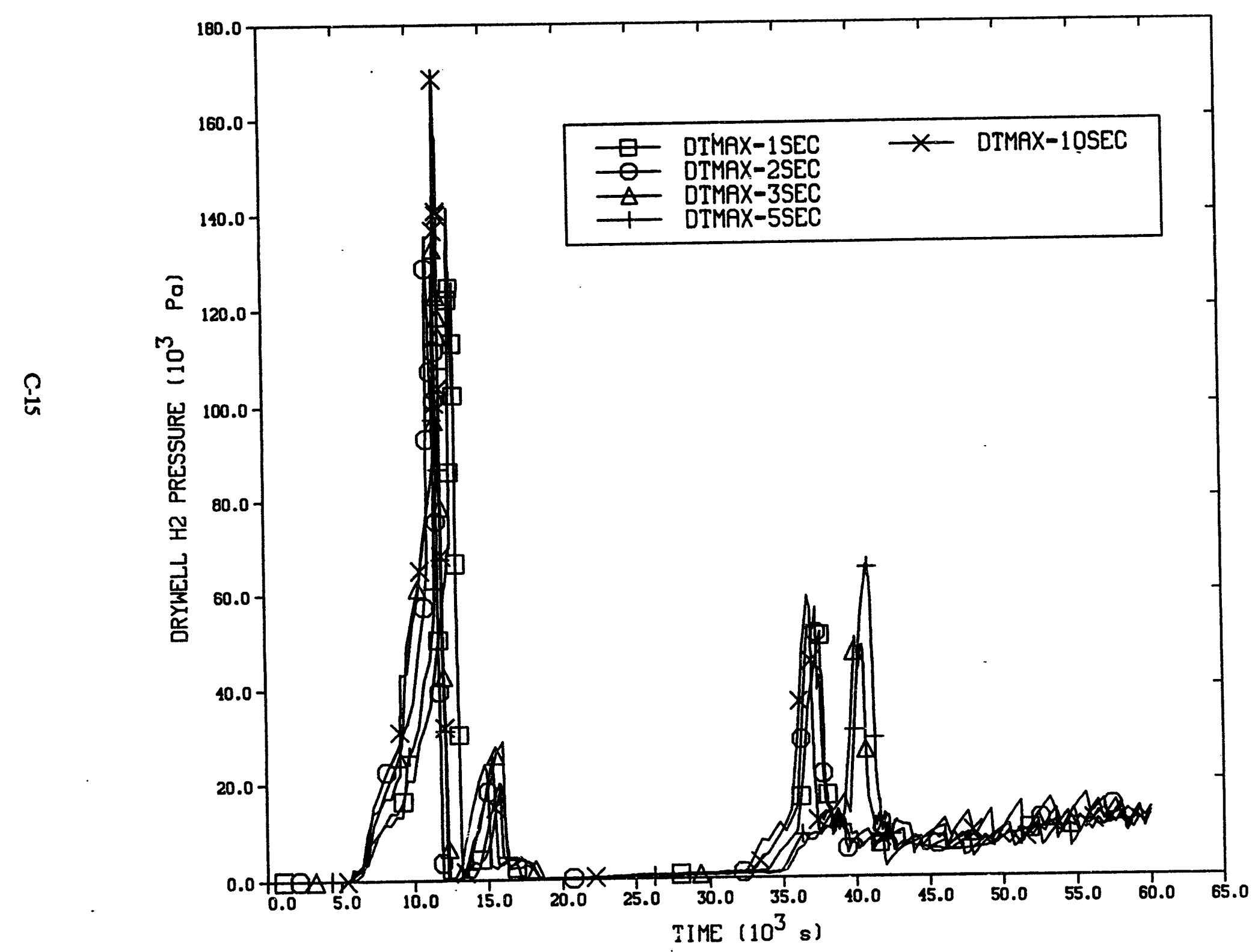


Figure C.12 Temperature of atmosphere in drywell

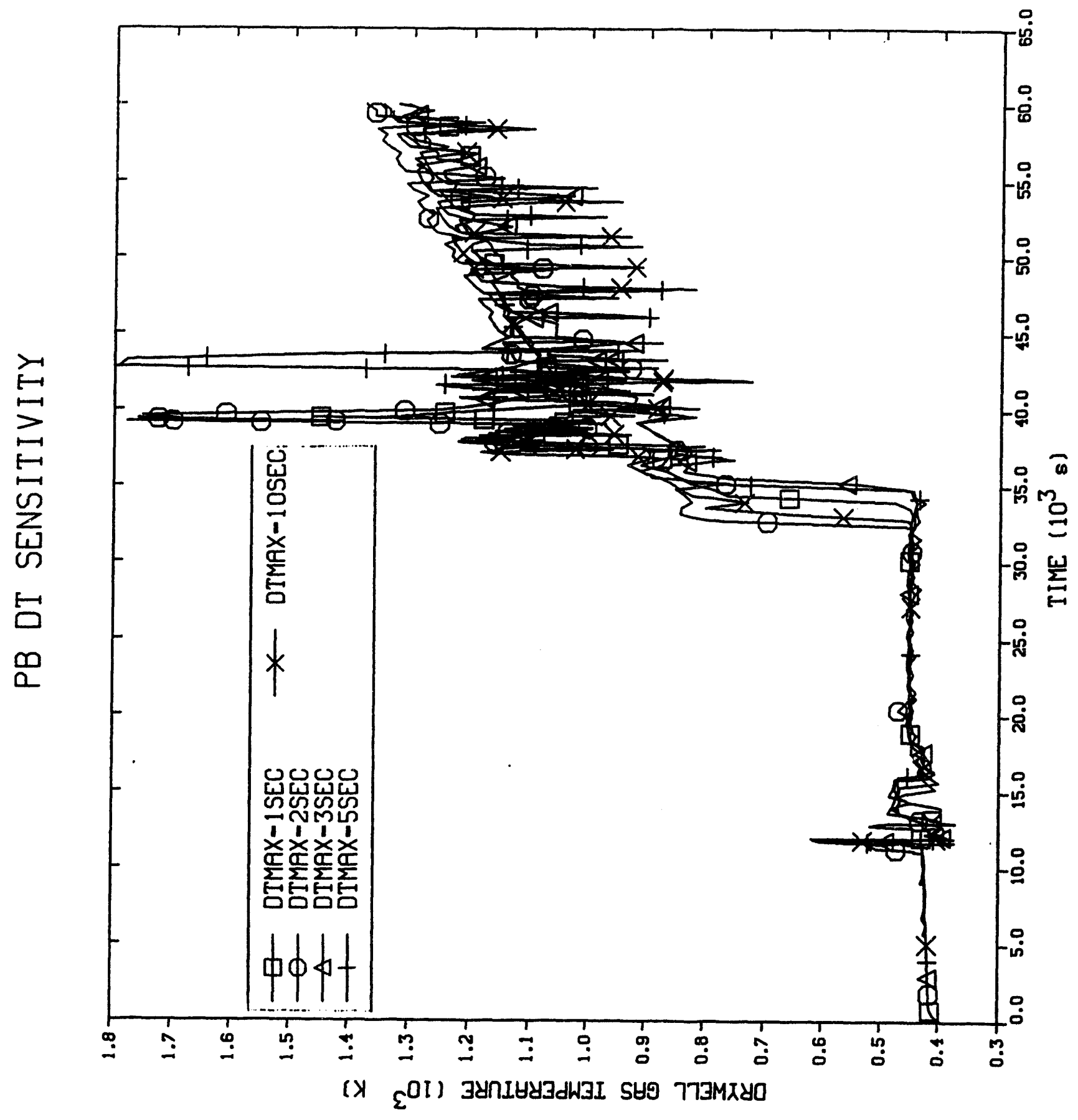




\section{PB DT SENSITIVITY}

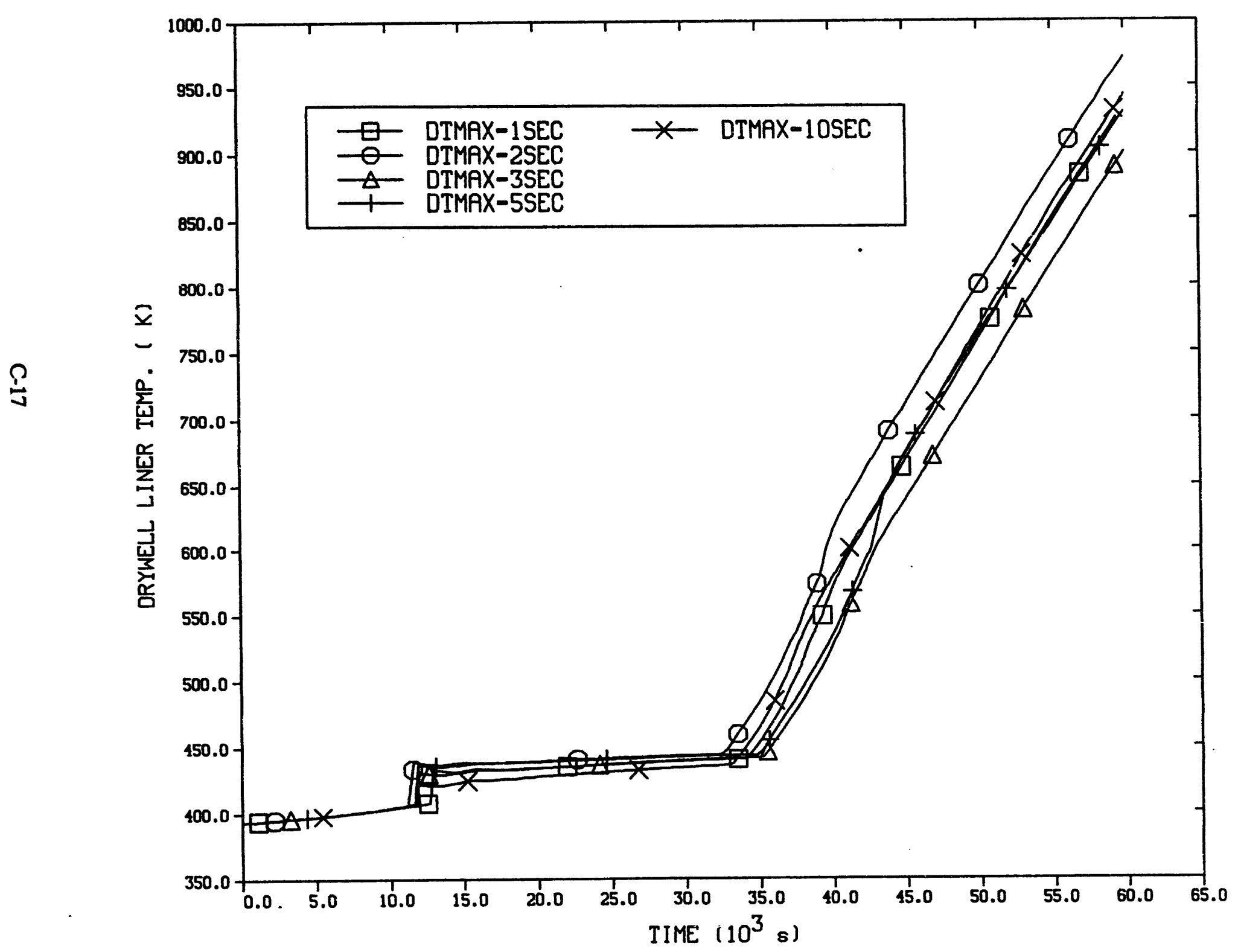




\section{PB DT SENSITIVITY}

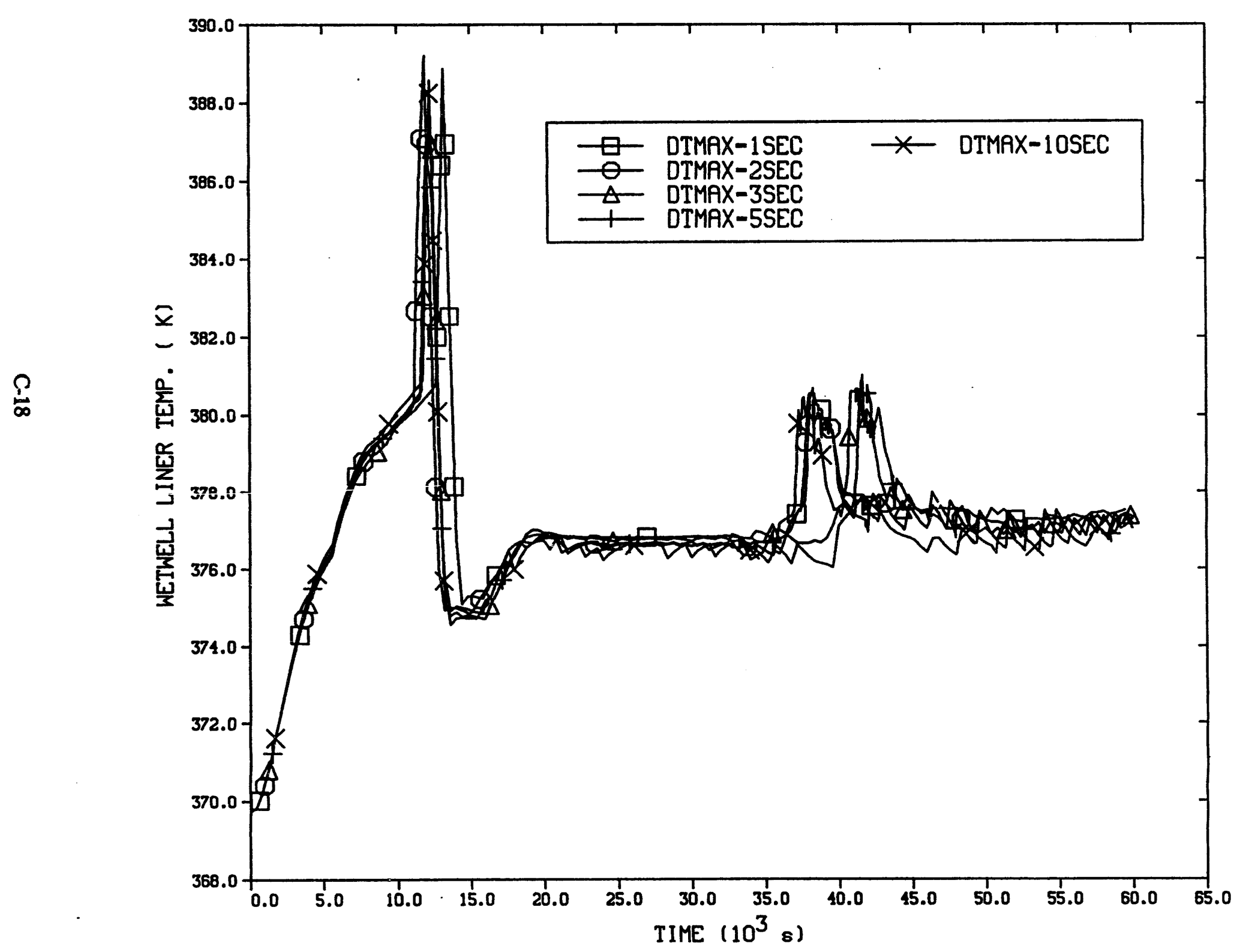


PB DT SENSITIVITY

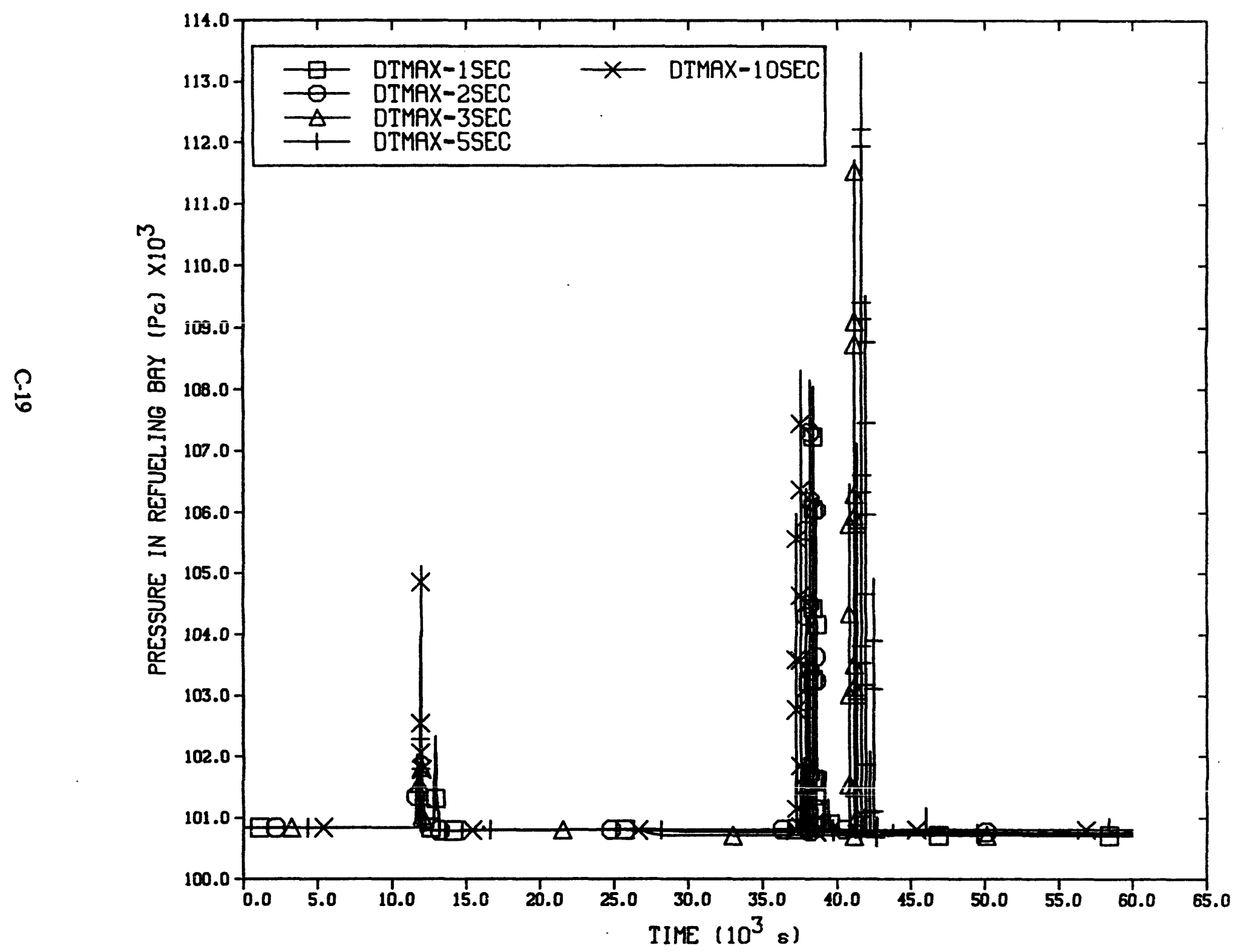


PB DT SENSITIVITY

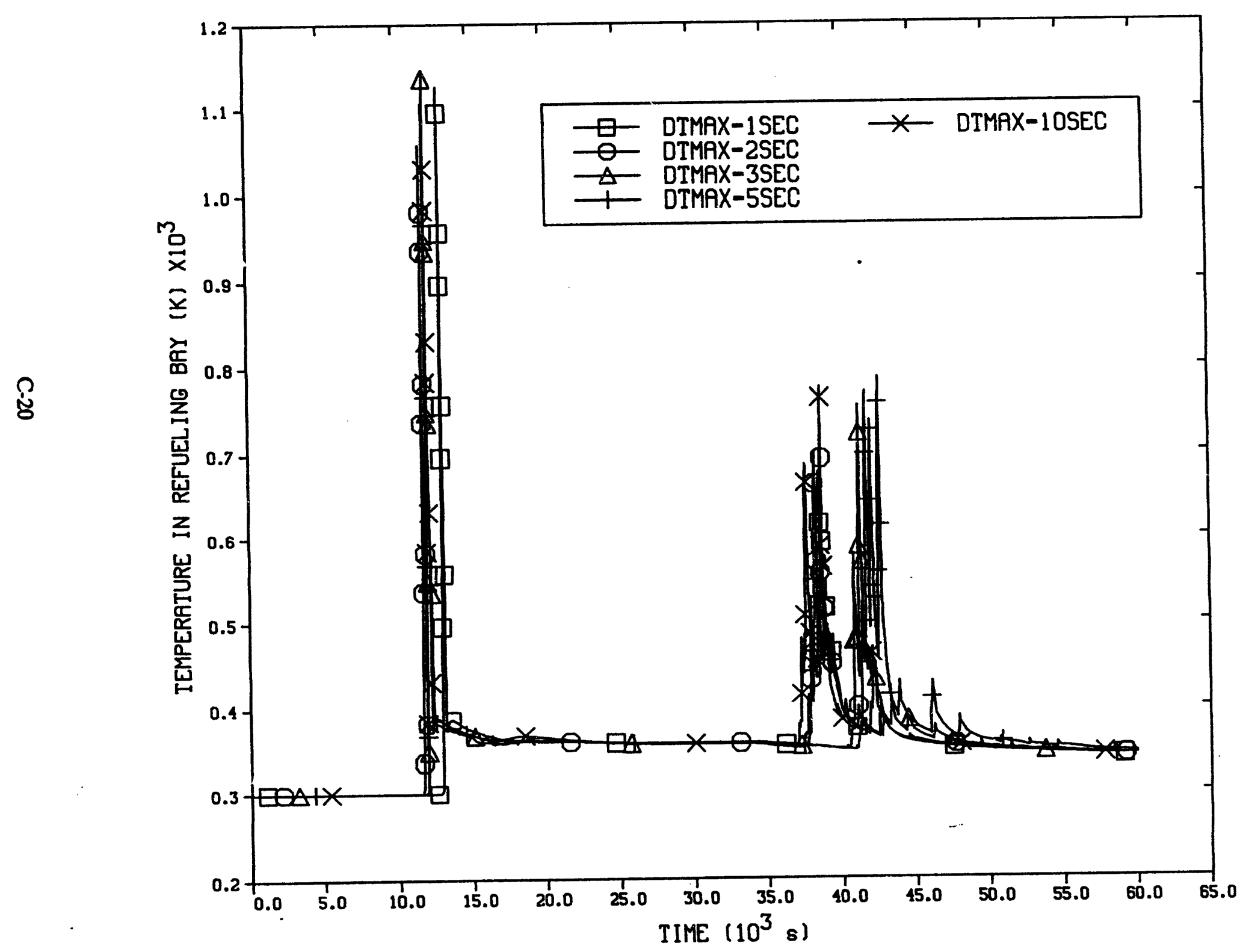


PB DT SENSITIVITY

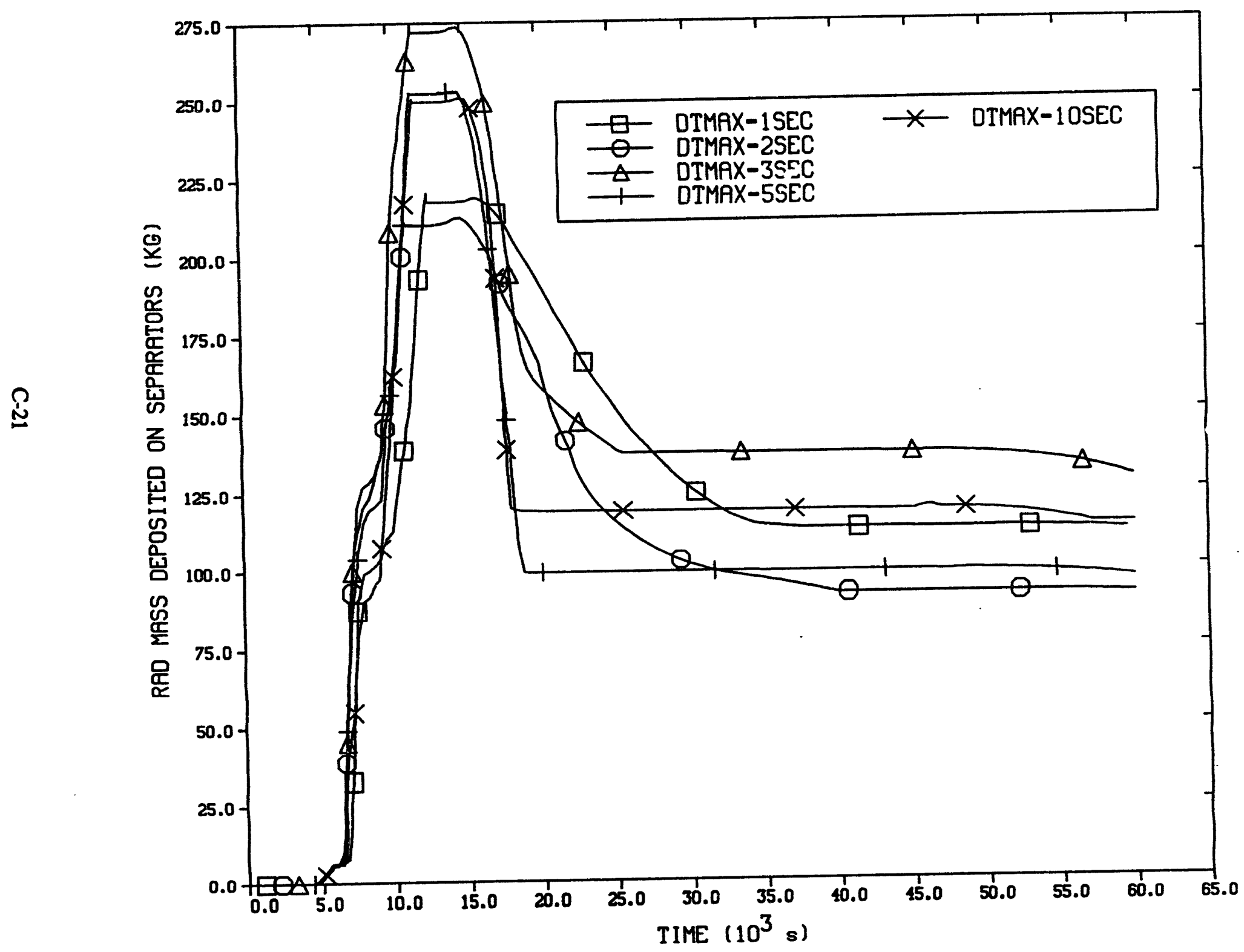




\section{C.2 Impact of Debris Fall Velocity in the New Debris Quench Model on Peach Bottom Station Blackout Calculations Using MELCOR 1.8.2}

The falling debris quench model became available with the latest released version of MELCOR (1.8.2). When activated, this model allows the debris to lose heat to surrounding water in the lower plenum as it falls to the lower head, following failure of the core support plate in each radial ring.

The debris is assumed to fall with a user-specified velocity (VFALL, default value of $5 \mathrm{~m} / \mathrm{s}$ ). Heat transfer from the falling debris to the pool of water in the lower plenum is calculated using a user-specified quench heat transfer coefficient $\left(750 \mathrm{~W} / \mathrm{m}^{2}-\mathrm{K}\right.$ in all calculations reported here), and the surface area of the debris particles with user-specified particulate debris equivalent diameter of $0.01 \mathrm{~m}$. This heat transfer may or may not be sufficient to fully quench the de.bris before it reaches the bottom of the lower plenum, depending on the values selected for the model input parameters.

Calculations for the low pressure station blackout sequence [23] showed that, when the default value for VFALL was used, the results with or without the debris quench model activated were very similar, with vessel failure always preceding lower plenum dryout. This could, perhaps, be attributed to VFALL being too high, not allowing enough time for debris to quench.

The case for a lower VFALL can be made based on the maximum velocity attainable for debris particles falling over a small height of a few meters, against the drag of water in the lower plenum. In the calculations of the previous section (\$C.1), to ensure that lower plenum dryout occurs prior to vessel failure, VFALL was reduced to $0.1 \mathrm{~m} / \mathrm{s}$ [24] and debris particle diameter was reduced from $0.0254 \mathrm{~m}$, used in earlier Peach Bottom calculations [1,2] to $0.01 \mathrm{~m} \mathrm{[24]}$. This parameter selection always resulted in lower plenum dryout prior to vessel failure (see Table C.1).

The impact of debris fall velocity was examined by carrying out complete sequence calculations selecting three variations of VFALL $(0.1,1.0$, and $5.0 \mathrm{~m} / \mathrm{s})$.

Table C.3 presents MELCOR-calculated timing of key events. Up to the point of core support plate failure in Ring 1, all 3 calculations are identical, as expected, since the debris quench model comes into play only after the core support plate fails. Thereafter, it can be seen that, while for VFALL $=0.1 \mathrm{~m} / \mathrm{s}$ and $1.0 \mathrm{~m} / \mathrm{s}$, lower plenum dryout precedes vessel (penetration) failure, for VFALL $=5.0 \mathrm{~m} / \mathrm{s}$, penetrations fail prior to lower plenum dryout. This finding is consistent with calculations of the low pressure sequence, and can be attributed to insufficient debris quenching due to a very high VFALL. Furthermore, for VFALL $=5.0 \mathrm{~m} / \mathrm{s}$, all penetration failures occur together. This can be attributed to the debris radial relocation model, available in MELCOR 1.8.2, that allows very hot, unquenched debris to relocate to all 3 rings. All 3 cases, however, lead to early drywell failure.

For VFALL $=0.1 \mathrm{~m} / \mathrm{s}$, debris ejection to cavity occurs after a substantial delay following vessel (penetration) failures, while it occurs immediately following vessel failure for VFALL $=1.0 \mathrm{~m} / \mathrm{s}$ and $5.0 \mathrm{~m} / \mathrm{s}$. This is because, for VFALL $=0.1 \mathrm{~m} / \mathrm{s}$, the debris being completely quenched, is at lower temperature when it fails the penetrations, and requires time to heat up and partially melt, prior to being ejected to the cavity.

Table C. 4 presents MELCOR-calculated environmental releases of radionuclides. The impact of VFALL is seen to be very small except for VFALL $=5.0 \mathrm{~m} / \mathrm{s}$, which results in noticeably lower 
release fractions of the refractories $\mathrm{Ru}, \mathrm{Mo}, \mathrm{Ce}, \mathrm{Sn}$ (factor of 2 lower) and $\mathrm{Cd}$ (factor of 4 lower). The results indicate that, for VFALL $=5.0 \mathrm{~m} / \mathrm{s}$, there is a substantially larger inventory of radionuclides in the wetwell, hence more retention. This could be partially attributed to more rapid pressurization of the drywell following vessel failure, and consequently greater steam flow to the wetwell prior to drywell failure, for VFALL $=5.0 \mathrm{~m} / \mathrm{s}$.

Table C.3 Impact of Debris Fall Velocity in new Debris Quench Model on Predicted Timing of Key Events (MELCOR 1.8.2)

\begin{tabular}{|c|c|c|c|c|}
\hline \multirow{2}{*}{\multicolumn{2}{|c|}{ Key Event }} & \multicolumn{3}{|c|}{ Tnee (eac) } \\
\hline & & VFALL $=0.1 \mathrm{~m} / \mathrm{s}$ & VFALL $=1.0 \mathrm{~m} / \mathrm{s}$ & VTALL $=5.0 \mathrm{~m} / \mathrm{L}$ \\
\hline \multirow{3}{*}{ Gap Release of Mission Products } & Ring 1 & 4668.2 & 4668.2 & 4668.2 \\
\hline & Ring 2 & 5116.7 & 5116.7 & 5116.7 \\
\hline & Ring 3 & 8526.0 & 8526.0 & 8526.0 \\
\hline \multirow{3}{*}{ Core Collapee } & Ring 1 & $11,713.7$ & $11,713.7$ & $11,713.7$ \\
\hline & Ring 2 & $11,726.5$ & $11,727.5$ & $11,717.5$ \\
\hline & Ring 3 & $12,533.9$ & $13,204.3$ & $13,651.1$ \\
\hline \multicolumn{2}{|l|}{ Lower Plemom Dryout } & $11,765.5$ & $11,735.4$ & $11,834.7$ \\
\hline \multirow{3}{*}{ Vessel (Penetration) Failure } & Ring 1 & $12,244.5$ & $11,758.3$ & $11,760.4$ \\
\hline & Ring 2 & $11,785.9$ & $11,770.2$ & $11,760.4$ \\
\hline & Ring 3 & $11,785.9$ & $11,770.2$ & $11,760.4$ \\
\hline \multicolumn{2}{|l|}{ Reactor Veasel Depresaurized } & $11,894.5$ & $11,870.8$ & $11,898.2$ \\
\hline \multicolumn{2}{|l|}{ Drywell Fallure (Overpressure) } & $11,953.9$ & $12,002.2$ & $11,898.2$ \\
\hline \multicolumn{2}{|c|}{ Deliagrations Begin in Reactor Buildine } & $11,960.8$ & $12,014.5$ & $11,906.9$ \\
\hline \multicolumn{2}{|l|}{ Debris Ejection to Cavity Begins } & $15,352.8$ & $11,770.2$ & $11,760.4$ \\
\hline \multicolumn{2}{|l|}{ End Calculation } & $60,000.0$ & $60,000.0$ & $60,000.0$ \\
\hline
\end{tabular}


Table C.4 Impact of Debris Fall Velocity in New Debris Quench Model on Predicted Environmental Releases of Radionuclides (MELCOR 1.8.2)

\begin{tabular}{|c|c|c|c|}
\hline \multirow{2}{*}{ Class } & \multicolumn{3}{|c|}{ Environmontal Rolease (Fraction) } \\
\hline & VTALL $=0.1 \mathrm{a} / \mathrm{s}$ & VTALL $=1.0 \mathrm{~m} / \mathrm{s}$ & VTALL $=5.0 \mathrm{~m} / \mathrm{s}$ \\
\hline $\mathbf{X e}$ & 0.995 & 0.994 & 0.995 \\
\hline Cs & 0.386 & 0.412 & 0.324 \\
\hline Ba & 0.107 & 0.110 & 0.114 \\
\hline Te & 0.143 & 0.130 & 0.120 \\
\hline $\mathbf{R u}$ & $0.404 E-03$ & $0.325 E-03$ & $0.118 E-03$ \\
\hline Mo & $0.890 \mathrm{E}-02$ & $0.834 \mathrm{E}-02$ & $0.473 E-02$ \\
\hline Ce & $0.122 \mathrm{E}-04$ & $0.108 \mathrm{E}-04$ & $0.552 \mathrm{E}-05$ \\
\hline $\mathbf{L a}$ & $0.144 \mathrm{E}-02$ & $0.178 \mathrm{E}-02$ & $0.165 E-02$ \\
\hline $\mathbf{U}$ & $0.449 \mathrm{E}-04$ & $0.377 \mathrm{E}-04$ & $0.203 E-04$ \\
\hline Cd & $0.961 \mathrm{E}-02$ & $0.789 \mathrm{E}-02$ & $0.247 \mathrm{E}-02$ \\
\hline $\mathbf{S n}$ & $0.119 \mathrm{E}-01$ & $0.105 E-01$ & $0.509 \mathrm{E}-02$ \\
\hline $\mathbf{B}$ & 0.0 & 0.0 & 0.0 \\
\hline $\mathbf{H}_{2} \mathbf{O}$ & 0.0 & 0.0 & 0.0 \\
\hline Concrete & 0.0 & 0.0 & 0.0 \\
\hline Cal & 0.389 & 0.413 & 0.349 \\
\hline
\end{tabular}




\section{C.3 Implementation of ORNL's Lower Plenum Debris Bed (BH) Model}

The BH model is now available to users as an option with MELCOR version 1.8.2. The BH package calculates the thermal response of the lower plenum debris, the heatup of the reactor vessel bottom head, and the release of core and structural materials from the reactor vessel to the drywell. BH calculations begin when the BWR lower plenum is dry, and when sufficient solid debris mass has accumulated to form the foundation of a debris bed. (Prior to these conditions being established, the original COR package models are used to determine the lower plenum debris bed/bottom head response.) Material subsequently relocated downward from the core region (solids and liquids) are added to the upper surface of the bed. Materials released from the lower plenum via penetration failures or bottom head creep rupture are transferred to the containment drywell.

Table C.5 presents MELCOR-calculated timing of key events using the BH model. Compared with results using the standard MELCOR lower head model, all events are slightly delayed (except for debris ejection to cavity). This delay is consistent with calculations reported by ORNL for LaSalle [24]. Note that, even though the BH calculation begins only after the lower plenum dries out, there is a simple model implemented in the BH package to calculate radiative heat transfer between the core shroud and the reactor vessel wall, which gets activated at the very outset of the MELCOR simulation. The differences in timing of key events prior to lower plenum dryout observed between the standard MELCOR calculation and that employing the $\mathrm{BH}$ package, both in the present simulation (Table C.5), and in ORNL's LaSalle calculation [24], could be attributed to this additional model. Once again, there is early drywell failure shortly after vessel (penetration) failure.

Vessel failure first occurs at 12,707 sec due to penetration weld temperature exceeding DTFAIL (temperature threshold for creep rupture of the weld). DTFAIL is calculated by the BH package based on two input parameters THK6 (temperature for creep rupture in $6 \mathrm{~min}, \mathrm{~K}$ ) and THK60 (temperature for creep rupture in $60 \mathrm{~min}, \mathrm{~K}$ ). Values for these parameters were selected as $1295 \mathrm{~K}$ and $1210 \mathrm{~K}$, respectively, based on suggested values in the Users' Guide (BH-UG-11) for a high pressure sequence [25]. Debris ejection starts shortly thereafter. Global bottom head failure due to creep rupture occurs at $26,772.7 \mathrm{sec}$, at which time all remaining debris in the lower plenum is transferred to the drywell.

Radionuclide releases to the environment calculated using the $\mathrm{BH}$ model were significantly lower than those for the reference case using the MELCOR LH model. The results are not presented here since the BH Package is still undergoing extensive additional development at ORNL, and its integration into MELCOR, including the interface with the Radionuclide Package, is incomplete [24]. 
Table C.5 Predicted Timing of Key Events Using MELCOR LH Model and ORNL's BH Model (MELCOR Version 1.8.2)

\begin{tabular}{|c|c|c|c|}
\hline \multirow{2}{*}{\multicolumn{2}{|c|}{ Key Event }} & \multicolumn{2}{|c|}{ Time (sec) } \\
\hline & & Standard MEICOR LH Model & ORNL's BH Model \\
\hline \multirow{3}{*}{ Gap Release of Irvion Products } & Ring 1 & 4668.2 & 4620.1 \\
\hline & Ring 2 & 5116.7 & 5077.3 \\
\hline & Ring 3 & 8526.0 & 8597.3 \\
\hline \multirow{3}{*}{ Core Collapee } & Ring 1 & $11,713.7$ & $12,294.4$ \\
\hline & Ring 2 & $11,726.5$ & $12,310.2$ \\
\hline & Ring 3 & $12,533.9$ & $14,082.7$ \\
\hline \multicolumn{2}{|l|}{ Lower Plenum Digout } & $11,765.5$ & $12,341.3$ \\
\hline \multicolumn{2}{|l|}{ Veasel (Penetration) Failure } & $11,785.9$ & 12.707 .0 \\
\hline \multicolumn{2}{|l|}{ Reactor Vessel Depreasurized } & $11,894.5$ & $12,746.0$ \\
\hline \multicolumn{2}{|l|}{ Drywell Failure (Overprescure) } & $11,953.9$ & $12,817.7$ \\
\hline \multicolumn{2}{|c|}{ Dellagrations Begin in Reactor Building } & $11,960.8$ & $12,819.2$ \\
\hline \multicolumn{2}{|l|}{ Debris Bjection to Cavity Beyins } & $15,352.8$ & $12,735.5$ \\
\hline \multicolumn{2}{|c|}{$\begin{array}{l}\text { Bottom Feed Failure Due to Croep Rupiure } \\
\text { (All remaining LP debris transferred to } \\
\text { drywell) }\end{array}$} & & $26,772.7$ \\
\hline \multicolumn{2}{|l|}{ Fad Calculation } & $60,000.0$ & $60,000.0$ \\
\hline
\end{tabular}




\section{REFERENCES}

21. MELCOR 1.8.2 Users' Guide/Reference Manual, Sandia National Laboratories, February 1993.

22. A. Elsbernd, Private Communication, July 7, 1993.

23. I.K. Madni, "Melcor 1.8.2 Analyses of In-Vessel Structure Temperatures and Debris Ejection Characteristics During a Low-Pressure Station Blackout in Peach Bottom," Draft Report A3281, SRED-16, Brookhaven National Laboratory, June 11, 1993.

24. S. A. Hodge, et. al., "BWR-Specific Models for MELCOR," presented at the 1993 CSARP Review Meeting, Bethesda, MD, May 3-7, 1993.

25. C. R. Hyman, Private Communication, June 3, 1993.

26. C. R. Hyman and R. L. Sanders, "BH Package Users' Guide, Version 1.0.3," Oak Ridge National Laboratory, December 31, 1992. 


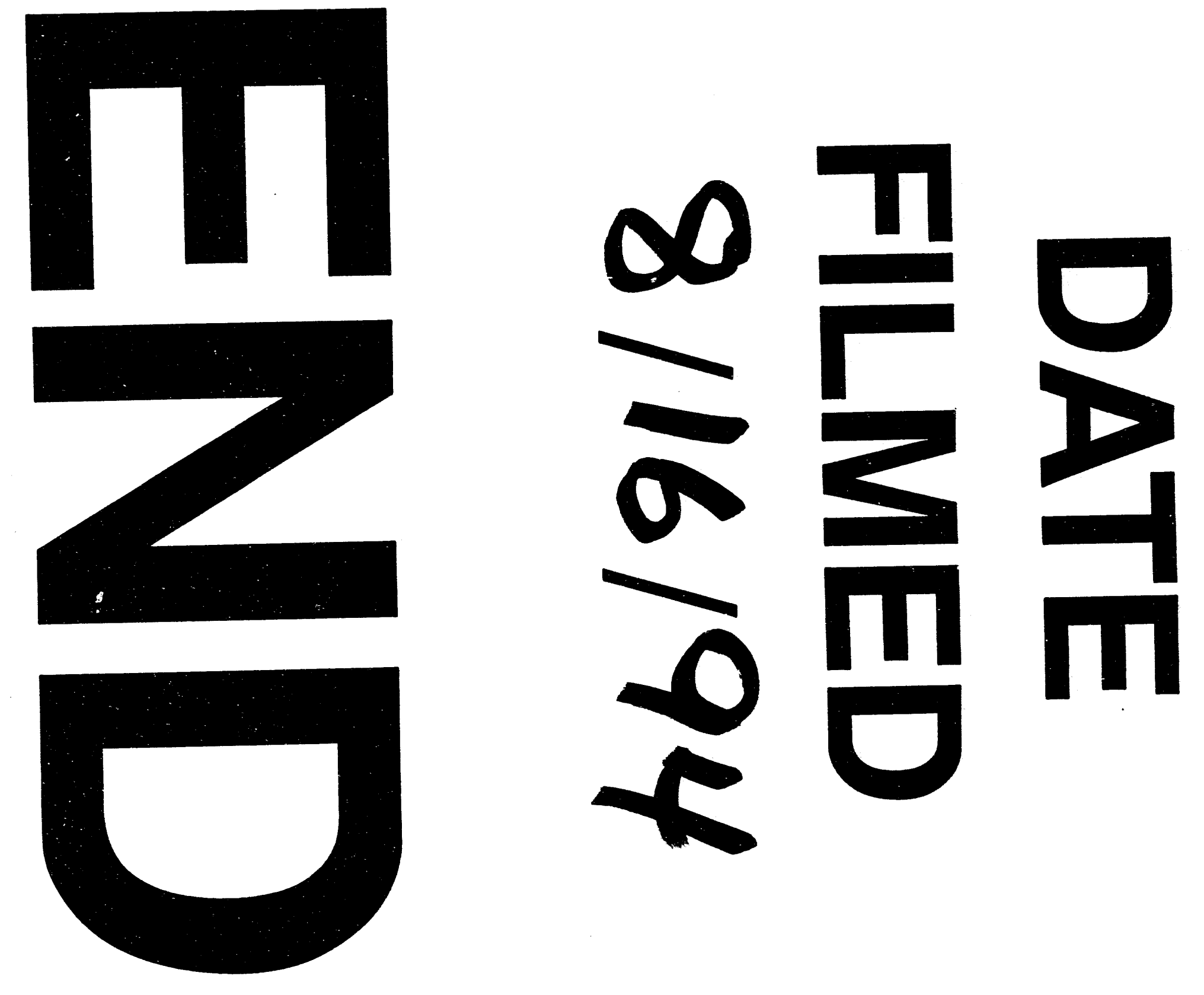


